\title{
The role of vitamin K-dependent proteins in tissue calcification
}

Citation for published version (APA):

Jie, G. K. S. (1995). The role of vitamin K-dependent proteins in tissue calcification. [Doctoral Thesis, Maastricht University]. Rijksuniversiteit Limburg. https://doi.org/10.26481/dis.19950623gj

Document status and date:

Published: 01/01/1995

DOI:

10.26481/dis.19950623gj

Document Version:

Publisher's PDF, also known as Version of record

\section{Please check the document version of this publication:}

- A submitted manuscript is the version of the article upon submission and before peer-review. There can be important differences between the submitted version and the official published version of record.

People interested in the research are advised to contact the author for the final version of the publication, or visit the DOI to the publisher's website.

- The final author version and the galley proof are versions of the publication after peer review.

- The final published version features the final layout of the paper including the volume, issue and page numbers.

Link to publication

\footnotetext{
General rights rights.

- You may freely distribute the URL identifying the publication in the public portal. please follow below link for the End User Agreement:

www.umlib.nl/taverne-license

Take down policy

If you believe that this document breaches copyright please contact us at:

repository@maastrichtuniversity.nl

providing details and we will investigate your claim.
}

Copyright and moral rights for the publications made accessible in the public portal are retained by the authors and/or other copyright owners and it is a condition of accessing publications that users recognise and abide by the legal requirements associated with these

- Users may download and print one copy of any publication from the public portal for the purpose of private study or research.

- You may not further distribute the material or use it for any profit-making activity or commercial gain

If the publication is distributed under the terms of Article $25 \mathrm{fa}$ of the Dutch Copyright Act, indicated by the "Taverne" license above, 
THE ROLE OF VITAMIN K-DEPENDENT PROTEINS IN TISSUE CALCIFICATION 
Omslag: R.W.M. van Baalen

Druk: Datawyse I Universitaire Pers Matastricht

\section{ISBN 90 52781958}

(c) K.S.G. Jic, Mastrich 1995 


\title{
THE ROLE OF VITAMIN K-DEPENDENT PROTEINS IN TISSUE CALCIFICATION
}

\author{
PROEFSCHRIFT
}

ter verkrijging van de graad van doctor aan de

Rijksuniversiteit Limburg te Maastricht, op gezag van de Rector Magnificus, Prof.Mr.M.J. Cohen, volgens het besluit van het College van Dekanen, in het openbaar te verdedigen op vrijdag 23 juni 1995 om 14.00 uur

door

Gerard Kon Siong Jie 
Promotor:

Prof. Dr. H.C. Hemker

Co-promotoren:

Dr. C. Vermeer

Dr. K. Hamulyák

Beoordelingscommisie: Prof. Dr. P.J. Brombacher (voorzitter)

Dr. G. Hornstra

Prof. Dr. J.A. Knottnerus

Prof. Dr. A.C. Nieuwenhuijzen Kruseman

Dr. M.J. Shearer (The Haemophilia Centre, London)

Financial support by the Netherlands Heart Foundation and by the Foundation Dr. Ir. J.H. van der Laar for the publication of this thesis is gratefully acknowledged. Additional support was kindly provided by ROCHE Nederland B.V. and SORIN Biomedica. 
How can we heal the wounds of the world If we cannot heal our ow? And where does this peace on earth begin If not in the home?

R. Ferrell

aan mijn ouders voor Liane Li-Juan, Paul en Lisa 


\section{ABBREVIATIONS}

B-AP

BGP

CBB

DBS

DDT

Gla

Glu

$\mathrm{HBC}$

HPLC

irOC

iroc

$\mathrm{irOC}_{\text {brend }}$

Menaquinone

MGP

$\mathrm{M}_{\mathrm{r}}$

OHPro

PG

PGP

Phylloquinone

PIVKA

PVDF

RIA

SDS-PAGE

T-AP

QAE bone-specific serum alkaline phosphatase

bone Gla protein, osteocalcin

coomassie brilliant blue

4-diazobenzenesulfonic acid

dithiothreitol

$\gamma$-carboxyglutamic acid

glutamic acid

hydroxyapatite binding capacity of serum osteocalcin (measure of Gla-content)

high performance liquid chromatography

serum immunoreactive osteocallcin

serum immunoreactive osteocalcin with a low affinity for hydroxyapatite (undercarboxylated osteocalcin)

serum immunoreactive osteocalcin with a high affinity for hydroxyapatite (carboxylated osteocalcin)

vitamine $\mathrm{K}_{2}$

matrix Gla protein

molecular weight

hydroxyproline

proteoglycan

plaque Gla protein

vitamin $\mathrm{K}_{1}$

protein induced by vitamin $\mathrm{K}$ absence of antagonists

polyvinylidenefluoride

radioimmunoassay

sodium dodecyl sulfate-polyacrylamide gel electrophoresis total serum alkaline phosphatase

quaternary amino ethyl 


\section{CONTENTS}

1 Introduction 9

1.1 General introduction 11

1.2 Vitamin K status $\quad 17$

1.3 Vitamin $\mathrm{K}$ and bone metabolism 20

1.4 Vitamin $\mathrm{K}$ and atherosclerotic calcifications 26

1.5 Introduction to this thesis 29

2 Serum osteocalcin as a marker for vitamin K-status in pregnant women and their newborn babies

3 Effects of vitamin $\mathrm{K}$ and oral anticoagulants on urinary calcium excretion

4 Vitamin $\mathrm{K}$ induced changes in markers for osteoblast activity and urinary calcium loss

5 Efficiency of phylloquinone (vitamin $\mathrm{K}_{1}$ ) absorption from spinach in human volunteers

6 A population-based study in women with or without atherosclerosis

6.1 Vitamin K intake and osteocalcin levels 87

6.2 Vitamin K status and bone mass 99

7 The isolation of $\gamma$-carboxyglutamic acid (Gla)-containing proteins

7.1. A specific colorimetric staining method

7.2 Gla-proteins in human atherosclerotic calcifications

8 Summary / samenvatting

Dankwoord

Publications

Curriculum vitae 

CHAPTER

1

\section{INTRODUCTION}





\subsection{GENERAL INTRODUCTION}

\section{Discovery of vitamin $K$ and vitamin $K$ antagonists}

In 1929 Henrik Dam reported the development of a bleeding disorder in chickens when fed a cholesterol depleted diet. ${ }^{1}$ The bleeding symptoms were caused by a deficiency of a fat-soluble factor, which appeared to be essential for the maintenance of a proper blood coagulation. He named this antihaemorrhagic factor vitamin $\mathrm{K}$ (according to Koagulation in the German spelling). ${ }^{2}$ Interestingly, the symptoms of the 'sweet clover disease" which prevailed among cattle in Canada and the American mid-west in the 1920's, showed many similarities with the bleeding disorder described by Henrik Dam. ${ }^{3}$ Improperly cured hay clover was found to be the cause of the disease. It was only several years later, however, that the connection with vitamin $\mathrm{K}$ could be made. In $194 \|$ the responsible component in improperly cured hay clover was identified as $3,3^{\circ}$-methylene-bis-(4-hydroxycoumarin) (trade name:dicumarol). It appeared that dicumarol functions as an antagonist of vitamin K. ${ }^{4}$ Several substituted 4-hydroxycoumarins were synthesized and are now widely used as anticoagulants (warfarin, phenprocoumon or acenocoumarol $)^{5}$ or rodenticides. "Their use has led to the discovery that plasma of anticoagulated man and cows contains abnormal, biologically inactive forms of several blood coagulation factors. ${ }^{78.9}$ Although the occurrence of these so called PIVKA's (Protein Induced by Vitamin K Absence or Antagonists) in plasma was already postulated in 1963 by Hemker et al. ${ }^{7,10}$ it took an additional ten years to understand the biochemical reason for their abnormal behaviour. In 1974 Stenflo discovered that the functionally inactive form of the blood coagulation factor prothrombin was lacking an unusual amino acid: $\gamma$-carboxyglutamate (Gla). "The highly negatively charged Gla appeared to be involved in the $\mathrm{Ca}^{34}$. dependent phospholipid binding, necessary for the biological activity of various blood coagulation factors. ${ }^{12,13}$

\section{Synthesis of Gla-proteins}

It is now clear that vitamin $\mathrm{K}$ is essential for the carboxylation of certain protein bound glutamic acid (Glu) residues into $\gamma$-carboxyglutamic acid (Gla) (Figure 1). Hence 'vitamin K-dependent' proteins are called Gla-proteins. The formation of Gla takes place during the posttranslational modification phase of protein synthesis. ${ }^{12,13}$ Although dietary vitamin $K$ is exclusively present as vitamin $K$ quinone $(\mathrm{K})$, it is its reduced form (vitamin $\mathrm{K}$ hydroquinone or $\mathrm{KH}_{2}$ ), that acts as the coenzyme for the vitamin K-dependent carboxylase (Figure 1). During the 


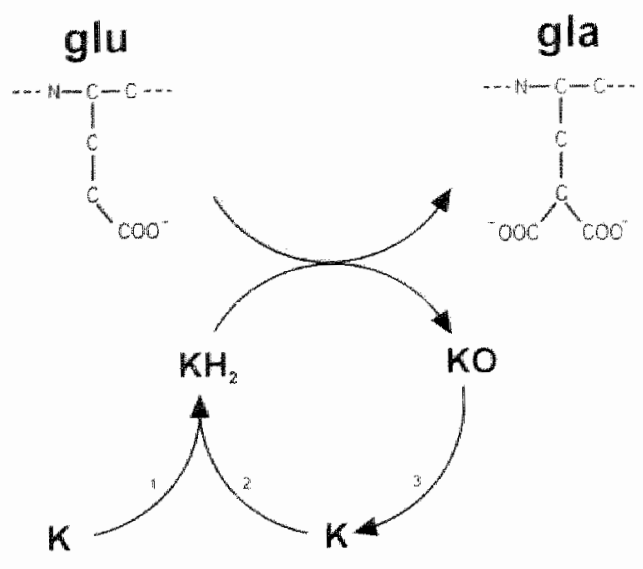

Figure 1. The vitamin $K$ cycle: vitamin $K$ is first reduced to $K H 2$, then oxidized to $K O$. During the oxidation step glutamic acd (Glw) is reduced to $\gamma$-carboryglutamic acid (Glat). Finally $K O$ is further reduced to $K . I=$ NADH-dependent reduciase, $2=$ dishol-dependen $K$-reductase, $3=$ dithol-dependent KO-reductase.

carboxylation reaction $\mathrm{KH}_{2}$ is converted to vitamin $\mathrm{K}$ epoxide $(\mathrm{KO})$. In its turn, $\mathrm{KO}$ is reduced to $\mathrm{K}$ and subsequently to $\mathrm{KH}_{2}$ by the action of two reductases (Figure 1). This recycling mechanism is very effective, explaining the rather low daily requirement for vitamin $\mathrm{K}$. The exact nature of the reductases is not known yet. In vitro studies have shown that both the $\mathrm{K}$ - and $\mathrm{KO}$-reductase are dithiol (dithiothreitol or thioredoxin)-dependent and they are both strongly inhibited by coumarin-derivatives. ${ }^{14,15}$ A blockade of (one of) the reductases ultimately leads to a cessation of the carboxylation reaction. The liver, however, contains a NADH-dependent $\mathrm{K}$-reductase which is not inhibited by vitamin $\mathrm{K}$-antagonists, and which exclusively reduces $\mathrm{K}$ and not $\mathrm{KO}$. Therefore, bleeding symptoms due 10 an intoxication with coumarins can be counteracted by high doses of vitamin $\mathrm{K}$, leading to the appearence of $\mathrm{KO}$ in plasma. There is some evidence from in vitro and in vivo studies that the osteoblast in bone tissue lacks the NADH-dependent $\mathrm{K}$-reductase. ${ }^{16}$ Feeding animals with vitamin $\mathrm{K}$ and warfarin effectively blocks the carboxylation of the bone Gla-protein osteocalcin, whereas their blood coagulation factors are maintained at a normal level..$^{17.18 .19}$

All Gla-proteins are secretory ones and are characterized by an intracellular precursor form possessing a "pre" and "pro" sequence. The hydrophobic presequence is required for translocation across the rough endoplasmic reticulum where it is subject to further posttranslational modifications such as pre-peptide cleavage, $\gamma$-carboxylation, disulphide bond formation, glycosylation, etc. The 
Table 1: Classification of Glaproteins

\begin{tabular}{|c|c|c|}
\hline Class: & $\begin{array}{l}\text { Occurrence or site of } \\
\text { synthesis }\end{array}$ & Characterised \\
\hline Blood coagulation & $\begin{array}{l}\text { Liver } \\
\text { Liver, andorhelial coll. } \\
\text { megakaryocyte }\end{array}$ & $\begin{array}{l}\text { Coagulation factors } \| I, \text { VII, } X \\
\text { and } X \\
\text { Proteins } C, S \text { and } Z\end{array}$ \\
\hline Calcifted tissues & $\begin{array}{l}\text { Bone } \\
\text { Atherosclerose } \\
\text { Kidney stones }\end{array}$ & $\begin{array}{l}\text { Osteocalcin. } \\
\text { Matrix Gla-protein (MGP) and } \\
\text { Protein S } \\
\text { Osteocalcin, MGP and Plaque } \\
\text { Gla-protein (PGP) } \\
\text { Kidney Gla-proteins }\end{array}$ \\
\hline Venoms & $\begin{array}{l}\text { Snake } \\
\text { Snail }\end{array}$ & \\
\hline Miscellaneous & $\begin{array}{l}\text { Various ussues, fibroblast and } \\
\text { endothelial cell } \\
\text { Spermatozoa } \\
\text { Urine }\end{array}$ & Nefrocalcin \\
\hline
\end{tabular}

pro-sequence serves as a recognition signal for the vitamin $\mathrm{K}$-dependent carboxylase. ${ }^{12,13}$ Structural elements required for recognition by carboxylase are thought to be the highly conserved amino acid residues at the positions -16 (Phe) and -10 (Ala/Gly) ${ }^{20}$ The Gla-clomain itself contains a sequence which is found in all mammalian Gla-proteins known thus far: Gla-X-X-X-Gla-X-Cys, but its relevance for the enzyme-substrate interaction is not clear at this time."

\section{Occurrence of Gla-proteins}

Milestones in the field of vitamin $K$ research have been the discovery of Gla in prothrombin" and the development of an in vitro assay system for vitamin Kdependent carboxylase enzyme from liver microsomes. ${ }^{22}$ These developments have provided a means with which to search for vitamin K-dependent proteins by analysing various tissues for the presence of the vitamin $\mathrm{K}$-dependent carboxylase enzyme and proteins for the presence of Gla. ${ }^{13}$ This has led to the discovery that the vitamin $\mathrm{K}$-dependent carboxylase enzyme is present in a wide variety of tissues such as the liver, bone, ${ }^{23}$ kidney, ${ }^{24}$ placenta, pancreas, skin, ${ }^{25}$ spleen, lung, testis ${ }^{26}$ and the vessel wall. ${ }^{27,28}$ In addition, the carboxylase enzyme has 
been detecied in cultured cells such as hepatocytes, renal tubule cells, fibroblasts, endothelial cells and various tumour cell lines. ${ }^{29}$ Despite the widespread distribution of the vitamin $\mathrm{K}$-dependent carboxylase, the actual number of well characterized Gla-proteins has been surprisingly low (Table 1 ).

The majority of the currently known Gla-proteins found in plasma belong to the Gla-proteins involved in blood coagulation: FII, VII, IX, X and the proteins $\mathrm{C}, \mathrm{S}$ and $Z$. Because they are mainly synthesized in the liver they are commonly referred to as the hepatic Gla-proteins. Gla-proteins belonging to the extra-hepatic group have been found in a wide variety of calcified tissues, such as bone (osteocalcin, ${ }^{30.31}$ matrix Gla-protein, ${ }^{32}$ protein $\mathrm{S}^{33.34}$ ), dentine ${ }^{35}$ (osteocalcin), calcium containing renal stones (kidney Gla-protein, ${ }^{36}$ ), heterotopic and cardiovascular calcifications ${ }^{37}$ (osteocalcin, plaque Gla-protein ${ }^{38}$ ) and coral. ${ }^{39}$ The second group of extra-hepatic Gla-proteins comprises a group of venoms from snakes and snails and finally a miscellaneous group including Gla-proteins identified in spermatozoa, ${ }^{40}$ snake, ${ }^{41.42}$ urine (nefrocalcin ${ }^{43}$ ) and snail ${ }^{44}$ venoms and a Gla-protein involved in growth arrest ('GAS-6"). ${ }^{45}$ Except for osteocalcin and MGP, the extra-hepatic Gla-proteins have not been characterized to a molecular levels, which hampers further research as to their function.

\section{Various forms of vitamin $\mathbf{K}$}

Compounds possessing 'vitamin $\mathrm{K}$ activity' are defined as compounds with antihaemorrhagic activity in animals fed a vitamin K-deficient diet. They have a 2-methyl-1,4-naphtoquinone ring structure in common but differ in length and the degree of saturation of their atliphatic side chain at the 3-position (Figure 2). Based on their origin, three main vitamin $\mathrm{K}$ compounds can be distinguished. Phylloquinone or vitamin $K_{1}$ (2-methyl-3-phyty $\mathbb{- 1 , 4 - n a p h t o q u i n o n e ) ~ i s ~ f o u n d ~ i n ~}$ plants and has the same phytyl side chain as chlorophyll. The second $\mathrm{K}$ vitamer is produced by certain bacteria and consists of a large group of compounds known as menaquinones or vitamin $\mathbb{K}_{2}$ (2-methyl-3-multi-prenyl-1,4-naphtoquinone). The menaquinones (MK-n) are distinguished from each other by the varying number (n) of isoprene residues in their unsaturated aliphatic side chain. Natural menaquinones range from MK-4 to MK-13. Finally, the synthetic homologue menadione (vitamin $\mathrm{K}_{3}$ ) contains no side chains (2-methyl-1,4-napthoquinone). Menadione should be regarded as a provitamin as it is first converted to menaquinone. ${ }^{46}$ Its bisulfite derivative is water soluble and mainlly used in animal foods as a vitamin $\mathrm{K}$ compound. In newborn babies its application has shown to lead to haemolysis and kernicterus, possibly due to the high reactivity of the 


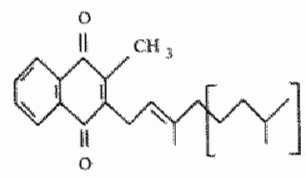

phylloguinone. $K_{\text {. }}$

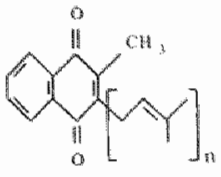

menaquinone $(M K-n), K$.

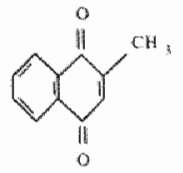

menadione, $\mathrm{K}_{3}$

Figure 2. Chewical struchures of phylloqumone (vitamin Kl), menaquinone (witamin $K 2$ ) and menadione (piramin $K 3$ )

unsubstituted 3-position. Its use in humans is therefore not recommended. ${ }^{47,48,49}$ If not further specified the term vitamin $\mathrm{K}$ will be used to describe a compound with vitamin $\mathrm{K}$ activity.

\section{Sources}

For humans the main source of phylloquinone is from green vegetables where it is found in tight association with chlorophyll. It is striking to note that there is relatively little data concerning the phylloquinone content of different food products. The limited number of published values vary widely, probably due to differences in detection methods, sampling size and sampling method. Variations due to differences in soil and growth conditions, geographical differences and time of harvesting have also been described. ${ }^{53}$ Various ways of processing such as heating, freezing and gamma-irradiation do not markedly influence phylloquinone levels in food. ${ }^{50.51}$ Vegetables with the highest vitamin $K_{1}$ concentration are green leafy vegetables such as spinach, kale, cabbage and broccoli $\left(30-1200 \mu \mathrm{g} / 100 \mathrm{~g}\right.$ edible portion). ${ }^{52.53}$

To date, there have only been a few reports on the menaquinone content in different food products. ${ }^{54,55,56}$ Significant amounts of menaquinones occur in fermented food products like cheese, yoghurt $(30 \mu \mathrm{g} / 100 \mathrm{~g})^{\text {si }}$ and the Japanese natto which is very rich in MK-7 $(900 \mu \mathrm{g} / 100 \mathrm{~g}) .^{54}$ Although the colon harbours considerable amounts of menaquinones producing bacteria (cg. E.Coli, B. Fragilis), ${ }^{57}$ it is highly questionable whether they are absorbed from this site. ${ }^{58.59 .60,61}$ Supporting data comes from Shearer et al. who describe that in 
Table 2: Mean fasting plastia phylloquinone levels in various groups

\begin{tabular}{lcc}
\hline & \multicolumn{2}{c}{ Plasma phylloquinone levels (ng/m) } \\
Subjects & Mean & Median \\
\hline & & \\
Heatlyy newborns (cords) & $\leq 0.02$ & 0.02 \\
Heatthy adults (fasting) & 0.41 & 0.37 \\
Healthy adults (non-fasting) & 0.66 & 0.53 \\
Pregnant women (at term) & 2.00 & 0.71 \\
Hypercholesterolaemiat & 0.76 & 1.97 \\
Hypertriglyceridaemia & 2.55 & 1.90 \\
Mixed layperlipidaemia & 4.60 & 0.35 \\
Diabetes (normal lipids) & 0.62 & 0.72 \\
Diabetes (raised lipids) & 0.88 & 0.41 \\
Hatmodialysis patients & 0.74 & - \\
\hline
\end{tabular}

Party adapted from ret. 64

human volunteers variable amounts of menaquinones (MK6 to MK10) are present in endoscopically obtained ileal juice. These menaquinones were mainly membrane-bound, however, since they could be removed from the ileal juice by centrifugation of the sample. Their bioavailablity, therefore, must be regarded as being low. ${ }^{56}$

\section{Absorption, transport and storage}

There is no information on the efficacy with which vitamin $K$ is liberated from different food products. It has been suggested that the net absorption from food varies from $40-70 \% .{ }^{62}$ It is to be expected that this variations will be depended upon the source: the extraction of phylloquinone from vegetables, where it is tightly bound to the chloroplast membranes, will be less efficient than from dairy produce. ${ }^{63}$ Sudies performed with radiolabeled purified phylloquinone indicate that up to $80 \%$ of an oral dose is absorbed. ${ }^{64}$

The absorption of phylloquinone and menaquinone is thought to be comparable to that of the other fat soluble vitamins. Although some studies concerning the mechanism of absorption are frequently quoted, their relevance is highly questionable due to the non-physiological conditions used. ${ }^{65}$ Both bile salts and pancreas lipase are necessary components for the intraluminal solubilisation and subsequent absorption. ${ }^{\text {sf }}$ Their importance is illustrated by the finding that par- 
ticularly patients with cholestatic disease (impaired bile salt secretion) and to a lesser extent those with pancreas insufficiency, are prone to developing vitamin $\mathrm{K}$-deficiency. ${ }^{66}$ After its uptake by the intestinal mucosal cells, vitamin $\mathrm{K}$ is incorporated into chylomicrons, secreted into the lymph, after which it reaches the systemic circulation. ${ }^{64}$ Phylloquinone is mainly transported in the triglyceride rich lipoproteins. ${ }^{67,63}$ Higher plasma levels are generally found in non-fasting than in fasting subjects. ${ }^{67.68}$ Very high plasma phylloquinone levels are found in various lipid disorders (Table 2) ${ }^{68}$ Recently it has been suggested that plasma phylloquinone levels are genetically influenced by the apolipoprotein $\mathrm{E}$ genotype. an important determinant of the chylomicron-remnant clearance rate. ${ }^{69}$ Whether the extremely high vitamin K-levels observed in the lipid disorders are representative of their tissue vitamin $\mathrm{K}$-status remains to be investigated.

Presently available data indicates that the major vitamin $\mathrm{K}$ stores are located in the liver. Remarkably, the majority $(>90 \%$ ) of the human liver vitamin $\mathrm{K}$ store consists of long chain menaquinones and not phylloquinone. ${ }^{58.68}$ The bioavailability of the high hepatic menaquinone store is uncertain, since it has been shown that a vitamin $\mathrm{K}$-deficiency can be induced within a few weeks with a dietary restriction of phylloquinone. ${ }^{70}$ Also in bone tissue vitamin $\mathrm{K}$ (menaquinones and phylloquinone) levels comparable to those in the liver have been described. ${ }^{71}$ Data about their bioavailability, however, is lacking.

\subsection{VITAMIN K STATUS}

\section{Requirements of vitamin $\mathrm{K}$}

The minimal daily requirement of vitamin $\mathrm{K}$ has been estimated at $1-2 \mu \mathrm{g} / \mathrm{kg}$ body weight. This estimation, however, is based on the minimal dose needed for the secretion of fully carboxylated coagulation factors. ${ }^{72.70}$ The daily vitamin $\mathrm{K}$ intake reported in the literature varies from 50-500 $\mu \mathrm{g} / \mathrm{day}$, depending on the characteristics of the population studied. ${ }^{67,72,70}$ Clinical vitamin $\mathrm{K}$-deficiencies characterized by abnormal coagulation tests do not occur in the general healthy population. The daily nutritional vitamin $\mathrm{K}$ intake is therefore generally regarded as sufficient, as far as the blood coagulation factors are concerned. 


\section{Plasma vitamin $\mathrm{K}$ levels}

At the present time the low menaquinone levels still pose detection problems. Therefore the assessment of plasma vitamin $\mathbb{K}$ levels is generally based on phylloquinone levels. However, the exient to which the plasma phylloquinone levels reflect one's tissue vitamin $\mathrm{K}$-status is debated. As discussed earlier, the use of plasma phylloquinone levels as indicator of one's vitamin $\mathrm{K}$ status is limited by the marked influence of various lipids (notably the triglyceride-rich lipoproteins) and non-fasting state on circulating levels. The extremely low phylloquinone levels in newborn babies may be partly explained by the very low plasma lipoprotein levels at birth, and underestimate the vitamin $K$ stores in the tissues. ${ }^{36}$ It has been suggested therefore, that the ratio of plasma phylloquinone to plasma triglyceride would be a better index of vitamin $K$ status than plasma phylloquinone alone. ${ }^{67,63}$ Presently available data show that it is only in a limited number of cases (e.g. hospitallized patients with a poor nutritional status) that low phylloquinone levels as such may be indicative for impaired vitamin $K$ reserves. ${ }^{63}$

\section{Descarboxy-prothrombin}

Another way to define a person's vitamin $\mathbb{K}$ status may be through the detection of partially or non carboxylated Gla-proteins, the concentration of which should decrease after vitamin $\mathrm{K}$ supplementation. Traditionally, descarboxy-prothrombin has been used as a marker to detect a state of vitamin K-deficiency. Several tests for the detection of descarboxy-prothrombin have been described, the most sensitive one being based on monoclonal antibodies which specifically recognize descarboxy-prothrombin. ${ }^{73.74}$ Descarboxy-prothrombin is generally not found in the plasma of the apparently healthy population, but can be measured after severe dietary restriction of vitamin $\mathrm{K}$ for a few weeks. ${ }^{75,76}$ Using monoclonal antibodies to detect descarboxy-prothrombin, only very low concentrations are found in $20-89 \%$ of the healthy newborn babies. ${ }^{73,77}$

Descarboxy-prothrombin levels have been found in subjects with acute hepatitis and cirrhosis. Vitamin $\mathrm{K}$-supplementation did not decrease the descarboxyprothrombin levels, however, indicating that these subjects had an impaired vitamin $\mathrm{K}$-dependent carboxylation in the liver, but no vitamin $\mathrm{K}$-deficiency. ${ }^{78}$ In subjects with a hepatocellular carcinoma, descarboxyprothrombin is frequently found and may me used as a tumor marker. ${ }^{79}$ 


\section{Descarboxy-osteocalcin}

Since it has been shown that the liver preferentially extracts phylloquinone from the circulation, ${ }^{80.81}$ it must be questioned whether the hepatic coagulation factors are the most sensitive markers for vitamin K-deficiency. It is therefore conceivable that an impaired vitamin $\mathrm{K}$-status will sooner be apparent in extrahepatic tissues resulting for instance, in an undercarboxylation of the extrahepatic bone Gla-protein osteocalcin.

Osteocalcin is currently the most extensively studied extra-hepatic Gla-protein. This can largely be attributed to its relatively easy isolation and the availability of several detection kits. ${ }^{82,83}$ Osteocalcin has the calcium dependent and Gla-mediated (thus vitamin K-dependent) property to bind to hydroxyapatite crystals. Carboxylated osteocalcin can thus be distinguished from its undercarboxylated form by the reduced affinity of the latter for hydroxyapatite. Some researchers have described procedures based on column chromatography to distinguish between the carboxylated and undercarboxylated osteocalcin levels. These methods, however, are laborious, time consuming and require rather high serum osteocalcin concentrations. ${ }^{84,85}$ A much more practical procedure has been described and validated by Price et al. It is an in vitro hydroxyapatite binding assay for detecting serum carboxylated and undercarboxylated osteocalcin. ${ }^{18,86}$ Due to the ability of most immunoassays to recognize both forms of serum immunoreactive osteocalcin (irOC), a fraction with a low affinity for hydroxyapatite ( $\mathrm{irOC}_{\mathrm{free}}$ or undercarboxylated osteocalcin) can be distinguished from a fraction with a high affinity (irOC $\mathrm{C}_{\text {bound }}$ or carboxylated osteocalcin) for hydroxyapatite (Figure 3). ${ }^{17} \mathrm{IrOC}_{\text {bound }}$, expressed as a percentage of total serum osteocalcin is called the hydroxyapatite binding capacity of osteocalcin (HBC) and is regarded as a measure for osteocalcin Gla-content and for vitamin $\mathrm{K}$ status. ${ }^{89}$ In young, healthy adults the $\mathrm{HBC}$ values range between 70 and $80 \%$, and decreased values are found in subjects with an impaired vitamin K-status."

The first clinical studies using the hydroxyapatite assay, showed an impaired carboxylation of serum osteocalcin in subjects treated with coumarinderivatives. ${ }^{19.87 .88}$ One year later, Knapen et al. reported the occurrence of high levels of undercarboxylated osteocalcin in apparently healthy postmenopausal women, despite the presence of normal coagulation factors. Vitamin $\mathrm{K}$ supplementation significantly reduced the HBC levels to premenopausal values, suggesting that an impaired vitamin $\mathrm{K}$ status, which was not apparent in blood coagulation factors, was present in these women. ${ }^{89}$ Since these initial publications, several other investigators have used the hydroxyapatite binding assay as a measure for vitamin $K$ status, confirming the results of Knapen et al. ${ }^{69,88,90,91,92}$ Recently a study was published showing that a subclinical vi- 


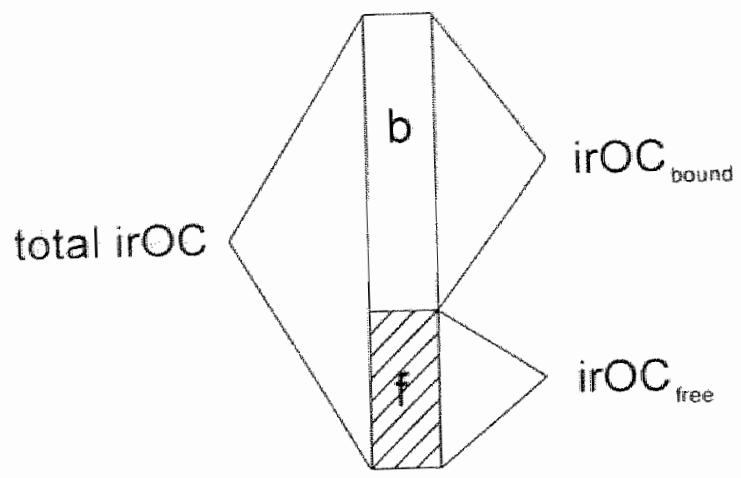

Figure 3. Total serm immintoreactive asteocalcin (total iroc) can be divided in a

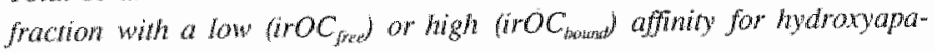
fite.

tamin K-deficiency can be induced in human subjects, without affecting blood coagulation factors. ${ }^{3}$ This further supports the view that blood coagulation factors may not be sensitive enough to detect a mild vitamin K-deficiency. ${ }^{59.94}$

\subsection{VITAMIN K AND BONE METABOLISM}

At this time three Gla-proteins have been identified in bone tissue: osteocalcin (also known as bone Gla protein or BGP), ${ }^{30.31}$ matrix Gla protein (MGP) ${ }^{32}$ and, most surprisingly, protein $S .{ }^{34}$ Although all three proteins are produced by the osteoblast, MGP and protein S are also synthesized by other cells (see below).

\section{Osteocalcin}

\section{Structure}

Osteocalcin is the most abundant non-collagenous protein in mature bone. ${ }^{30.31}$ It is a small $(5.7 \mathrm{kDa}) \mathrm{Ca}^{2+}$-binding protein of 49 amino acids, containing $3 \mathrm{Gla}$ residues at positions 17,21 and 24 . The molecule consists of two antiparallel $\alpha$ helical structures ("Gla'-helix from residues 16-25 and the 'Asp-Glu' helix from residues 30-41), stabilized by a disulphide bond between the positions 23 and 29 . This $\mathrm{Ca}^{2+}$ induced helical conformation is dependent on the presence of the Gla 
residues and important for the absorption of osteocalcin to hydroxyapatite. ${ }^{95}$ The biosymthesis of osteocalcin is regulated by the vitamins $D$ and $K$. Vitamin $D$ stimulates the transcription of mRNA, ${ }^{96,97}$ whereas vitamin $\mathrm{K}$ is involved in the posttranslational formation of Gla residues.

\section{Circulating levels}

After its synthesis by the osteoblast, about $80 \%$ of the newly synthesized osteocalcin is incorporated in the extracellular bone matrix and the remaining part is released into the circulation where it is assessable for detection. ${ }^{83.86 .98}$ Circulating osteocalcin is rapidly metabollised by the liver and kidney, and cleared by the kidney (half life time in rats: $5 \mathrm{~min}$ ) ${ }^{86.99}$ Serum osteocalcin levels are influenced by a variety of factors, including age, gender, renal function, medication (corticosteroids, anticonvulsant therapy, oral anticoagulants) and time of blood sampling (time of day and season) (for review see ref:82) ${ }^{83.97}$ Serum osteocalcin levels can be used as a specific marker for bone formation. ${ }^{82,101}$ Bone histomorphometric studies have shown that serum osteocalcin levels correlate with bone formation in several disease states. ${ }^{100,101,102,103}$ It has frequently been observed, however, that serum osteocalcin levels do not always correlate with serum levels of the more commonly used bone formation marker alkaline phosphatase. ${ }^{103,104,105}$ An explanation may be found in the hypothesis that these two bone formation markers reflect different aspects of osteoblast differentiation: alkaline phosphatase being an early marker and osteocalcin being a late marker of osteoblast differentiation.

\section{Detection assays}

Initially, detection of serum immunoreactive osteocalcin (irOC) levels was mainly based on competitive radioimmunoassays (RIA), using bovine osteocalcin as tracer, standard and immunogen. ${ }^{106}$ The succesful use of bovine or ovine osteocalcin is possible due to their high sequence homology with osteocalcin of human origin. Recent developments are the use of osteocalcin from human origin, the use of nonradioactive tracers $^{107}$ or enzyme-based immunoassays (EIA) and sandwich based assays (for review see ref:83). ${ }^{108.109}$ The published normal and pathological plasma osteocalcin values vary widely. ${ }^{83.110 .11}$ Several explanations have been given: differences in populations studied, assay format and species source of standard. One of the most important determinants, however, may be the different ability of the various antisera to additionally detect osteocalcin fragments. $109,112,113,114,115$

Several reports have indicated that varying amounts of circulating osteocalcin fragments are present in patients with chronic renal failure, ${ }^{109.112}$ in patients 
with Paget disease ${ }^{13}$ and in sera from healthy adults. ${ }^{113}$ It has been proposed that their presence is the result of release during the process of bone resorption, "15 generation in the circulation or occurring in vitro after blood sampling. ${ }^{116}$ It has been shown recently, that fragments resulting from proteolytic cleavage at the peptide bounds 19-20 and 43-44, can be detected in human plasma. ${ }^{106,116} \mathrm{~A}$ large $\mathrm{N}$-terminal midfragment (residues $1-43$ ) has been claimed to represent the majority $(76 \%-80 \%)$ of what was earlier regarded as the circulating "intact" osteocalcin molecule. The data from these authors showed that this $\mathrm{N}$-terminal midfragment is generated from proteolytic degradation of the intact molecule in the circulation and reflects formation rather than resorption. ${ }^{115}$

\section{Function}

Despite the large amount of research performed until now, the precise function of osteocalcin is still a matter of speculation. Evidence for a role in the regulation of bone mineralization are its abundance and specific association with the mineralized matrix, its appearance in bone tissue coinciding with the mineralization of bone and its ability to strongly inhibit hydroxyapatite crystal formation ${ }^{31}$ and hydroxyapatite precipitation from supersaturated solutions. ${ }^{31.117}$ Animal studies do not, however, unequivocally indicate an important role in bone matrix structure (see paragraph: vitamin $\mathrm{K}$ antagonists). Another possibility is that osteocalcin may be of importance for the maintenance of bone mass and bone remodelling by acting as a mediator of bone resorption: osteocalcin may act as a chemoattractant for osteoclasts and osteoclast progenitors by promoting osteoclastic differentiation. $118,4119,120$

\section{Matrix Gla-protein (MGP)}

MGP is a small $(9.6 \mathrm{kDa})$ Gla-protein containing 5 Gla residues. Despite its small size and hydrophillic amino acid composition, it is almost water-insoluble. MGP is unique among the known Gla-proteins, in the sense that it lacks a propeptide. In contrast to osteocalcin which is associated with the mineralized bone matrix, MGP is strongly associated with the organic bone matrix. ${ }^{32}$ MGP is not specific for bone and cartilage, ${ }^{12}$ but occurs in a wide variety of tissues including lung, heart, kidney, liver, spleen and vessel wall. ${ }^{122}$ In spite of its wide tissue distribution, substantial amounts of protein MGP levels have only been identified in the extracellular matrix of bone and cartilage. MGP mRNA transcription is regulated by vitamin $D$ and retinoic acid. ${ }^{123,124}$ The function of MGP is still unknown. In bone tissue, MGP is mainly expressed early in bone development, before the onset of mineralization. ${ }^{125}$ It has been suggested that it 
may clear extra-cellular calcium, thus protecting against tissue calcification in soft tissues. ${ }^{122}$ The retinoic acid dependent stimulation suggests that MGP could also be involved in the regulation of some aspects of cell growth and differentiation.

\section{Protein S}

Protein $\mathrm{S}$ is a single polypeptide chain molecule with an apparent molecular mass of $69 \mathrm{kDa}$ containing 11 . Gla residues. It is synthesized by hepatocytes, megakaryocytes and endothelial cells. In plasma about $50 \%$ is non-covalently bound to $\mathrm{C} 4 \mathrm{~b}$-binding protein, a protein involved in the complement system. ${ }^{12 \%}$ The other half is present in a free form and functions as a cofactor for activated protein $\mathrm{C}$ in the inactivation of the activated coagulation factors $V$ and VIII.

Based on their observation that two children with a congenital protein $S$ deficiency suffered from severe osteopenia. Pan et al. suggested that protein $\mathrm{S}$ may have a role in bone metabolism. ${ }^{127}$ This view was recently supported by Maillard et al. who showed that protein $S$ is synthesized and secreted by osteoblasts and could be identified in the organic bone matrix. ${ }^{34}$ In addition, these authors showed that another component of the protein $\mathrm{C}$ pathway, thrombomodulin, is synthesized by osteoblasts. It was shown that protein $\mathrm{C}$ can be activated at the cell membrane of the osteoblast. Interestingly, thrombomodulin expression is regulated by several mediators of osteoblast differentiation $\left(1,25(\mathrm{OH})_{2} \mathrm{D}_{3}\right.$, retinoic acid, IL1 and TNF $\alpha$ ). It has been hypothesized that thrombomodulin, protein $\mathrm{S}$ and $\mathrm{C}$ may be involved in regulating bone resorption by modulation of the plasmin system. ${ }^{128}$

\section{Vitamin $\mathrm{K}$ antagonists}

The abundant presence of Gla-protein in bone tissue, raises the question of whether the use of vitamin K-antagonists could be harmful for bone tissue. Human Warfarin Embryopathy, also known as the Fetal Warfarin Syndrome (FWS), is a well known result of coumarin use during the first trimester of pregnancy. Typical features are nasal hypoplasia and stippled epiphyses, extremity shortening and vertebral abnormalities. ${ }^{129}$ Although it cannot be excluded that these symptoms are the result of a direct toxic effect of warfarin on bone, an important role of vitamin $\mathrm{K}$ in normal bone development is supported by the description of a child with an inborn deficiency of the vitamin $K$ epoxide reductase, showing the same bone abnormalities associated with FWS. ${ }^{\text {ito }}$ In adults on the other hand, long-term oral anticoagulant therapy has never been associated with overt bone defects and only a few studies have investigated bone 
mass in these patients. The results of these studies are not consistent: three studies found no differences, ${ }^{131.132 .133}$ whereas two other study groups. reported a decreased bone mass in subjects on long-term warfarin therapy. ${ }^{34.135}$ A drawback of these studies is their case-control design and the sometimes limited number of subjects included. ${ }^{131,132}$

Initial animal studies regarding the effects of warfarin were hindered by the concomitantly induced bleeding symptoms. A breakthrough was the finding of Price et al. that simultaneously giving warfarin and vitamin $\mathrm{K}$ counteracted the bleeding symptoms, but not the effects of warfarin on bone tissue. ${ }^{17}$ All the animal studies investigating the effects of warfarin therapy (or dietarily induced vitamin $\mathrm{K}$ deficiency) have shown substantial reductions in osteocalcin or Glacontent of bone tissue (up to $2 \%$ of that of normal bone). The effects on bone morphology or histology, on the other hand, are not consistent and differ depending on the species of the animals used, their age and the duration of the treatment period. This can be explained, in part, by the fact that the critical periods for various aspects of skeletal development vary in the different animals and often occur in the early postnatal period..$^{18,136}$

Warfarin treatment for 6 weeks of chicken embryo's or newly hatched chickens did not reveal morphological bone defects. ${ }^{137}$ A recent study using a mild dietarily induced vitamin $\mathrm{K}$-deficiency on laying hens, and developing or young growing chicks for up to 28 weeks, did not show any effects on the gross or histological morphology of the bones either. ${ }^{138}$ On the other hand, by treating fetal rat pups during the gestational age of day 8 to 22 , Feteih et al. observed growth plate abnormalities such as an increased calcification and widening of hypertrophic zones, and disorganisation of the hypertrophic cells. ${ }^{139}$ Treating rabbits for 3 months with warfarin, did not reveal any effects on bone morphology, bone histology, bone strength, mineral and protein content. ${ }^{140}$ The same results were obtained when rats were treated from birth for 2 month. When the treatment was prolonged (up to 8 months), however, two studies described bone abnormalities consistent with those observed in the human FWS (fusion of growth plates, cessation of longitudinal bone growth, maxillonasal hypoplasia, etc). ${ }^{136.141}$ Pastoureau et al. described that, in contrast to the rat studies, treatment of newborn lambs with warfarin + vitamin $\mathrm{K}$ for 3 month, induced a severe osteopenia (30\% reduction in bone mass). The effects could be ascribed to a decrease in resorption and a more pronounced decrease in bone formation. ${ }^{142}$ 


\section{Effect of vitamin $K$ in cell culture and animal studies}

Most experimental work investigating the relationship between vitamin $\mathrm{K}$ and bone metabolism has been performed in Japan, using menaquinone-4 (menatetrenone). These studies all indicate that vitamin $\mathrm{K}$ stimulates bone formation and reduces bone resorption. Using several osteoblastic cell lines, two independent groups showed that menaquinone- 4 suppressed the proliferation of osteoblastic cells and stimulated bone forming activity as measured by the increased cellular excretion of alkaline phosphatase, osteocalcin, and enhanced mineral deposition. ${ }^{143,144}$

In one rat study it was demonstrated that a dietarily induced vitamin $\mathrm{K}$-deficiency leads to hypercalciuria. The high urinary calcium excretion was corrected by phylloquinone treatment within 7 days. ${ }^{145}$ The effect of menaquinone- 4 on bone loss was investigated in two rat studies. In the first study, bone loss was induced by ovariectomy. Vitamin $\mathrm{K}$ significantly suppressed the decrease in bone density, bone strength, calcium and hydroxyproline content of the femoral, respectively. ${ }^{146}$ In a second study it was shown that vitamin $K$ reduced prednisolone-induced bone loss. This was apparent through the diminished reduction in bone length, bone strength, calcium and hydroxyproline content of the femur. ${ }^{147}$ Studies performed with human osteoblastic cells and mouse calvaria organ cultures indicate that the suppressive effects of vitamin $\mathrm{K}$ on bone resor]tion can be explained in at least two ways. Besides a dose dependent inthibition of the powerful bone resorbing agent prostaglandin $E_{2},{ }^{148,149}$ vitamin $K$ has also been shown to inhibit bone resorption induced by parathyroid hormone and by 1,25-dihydroxyvitamin $\mathrm{D}_{3}{ }^{1.49}$

\section{Human intervention studies}

The presence of a marginal vitamin $\mathrm{K}$-status in postmenopausal women is suggested by studies which have shown that circulating vitamin $\mathbb{K}$ levels are reduced in elderly, ${ }^{67,150}$ and osteoporotic women (with a hip fracture). ${ }^{151.152 .153}$ Therefore, vitamin K-intervention studies have been mainly performed in elderly women. The results of the vitamin $\mathrm{K}$-supplementation studies are in line with the findings of the cell culture and animal studies described above. One of the first studies indicating that vitamin $\mathrm{K}$ influences calcium metabolism was a report from Tomita et al., who showed that vitamin K-treatment reduces calcium excretion in postmenopausal patients. ${ }^{154}$ By studying postmenopausal women living in a convent, Knapen et al. showed that vitamin $\mathrm{K}$ reduces urinary calcium excretion, but this was only observed in those with a high fasting urinary calcium loss. It was also shown that another marker of bone resorption, urinary hydroxyproline, 
decreased significantly upon witamin $\mathrm{K}$-treatment. An unexpected finding was that the majority of the women had low serum immunoreactive osteocalcin (irOC) levels, as well as a low Gla-content of their irOC (apparent in their low HBC levels). ${ }^{89}$ This situation is similar to that of subjects using vitamin $\mathrm{K}$-antagonists. ${ }^{108}$ Additional support for the view that the postmenopausal women had a subclinical vitamin $\mathrm{K}$-deficiency was the fact that vitamin $\mathrm{K}$-treatment improved the low HBC levels to premenopausal values. The occurrence of high levels of undercarboxylated osteocalcin in postmenopausal women has been confirmed by others $^{91}$ and recent evidence even indicates that high levels of undercarboxylated osteocalcin are associated with a six-fold increased risk for developing a hip fracture. ${ }^{155}$ Further support for the view that vitamin $\mathrm{K}$ influences bone metabolism comes from two Japanese studies which show that high doses of menaquinone significantly reduce the loss of bone mass or even increase bone mass in haemodialyis or osteoporotic patients. ${ }^{156,157}$

\section{Side effects of vitamin $K$ supplementation}

As mentioned earlier, vitamin $K_{3}$ or menadione is not recommended for use in humans, due to its haemolytic effects. ${ }^{47,49}$ Although intramuscular (and not oral!) phylloquinone supplementation to newborn babies has been linked to an increased risk of childhood cancer, ${ }^{158}$ several other studies have failed to confirm these findings. ${ }^{159,160,161}$ In adults, on the other hand, toxic effect of vitamin $\mathrm{K}$ supplementation have not been described despite the very high dosage used in several trials. ${ }^{156,157.062}$

\subsection{VITAMIN K AND ATHEROSCLEROTIC CALCIFICATIONS}

\section{Mechanism of atherosclerotic calcification: related to osteogenesis?}

Atherosclerosis is the underlying cause of cardiovascular disease, accounting for the majority of deaths occuring in industrialized countries. ${ }^{163}$ The atherosclerotic process is the result of an excessive inflammatory-fibroproliferative response to various forms of injuries to the endothelium and smooth muscle cells of the artery wall. This elicits a chronic, inflammatory response characterized by invasion of leucocytes and accumulation of cholesterolesters. A wide variety of cells participate in this complex process, including smooth muscle cells, platelets, macrofages and endothelial cells. These cells are involved in the 
production of different cytokines, various regulatory growth factors and extracelIular matrix proteins such as elastin, collagen and proteoglycans. ${ }^{164.165,160}$

Although much insight has been gained in the process of plaque formation. the understanding of the calcification process in the atherosclerotic vessel wall is still incomplete. Atherosclerotic calcification is regarded as a form of dystrophic calcification, which occurs in degenerating tissues, in the presence of normal serum caicium and phosphate levels. In contrast, metastatic calcification occurring in injured tissue is always associated with elevated calcium and/or phosphate levels. ${ }^{167}$ It has been reported that calcification is initiated in extracellular membrane-bound vesicles. These vesicles are thought to be derived from degraded smooth muscle cells and are morphological similar to the matrix vesicles found in bone and cartilage. ${ }^{168.169}$ In addition, several extracellular matrix components present in the plaque, such as elastic fibers, ${ }^{170}$ proteoglycans and collagen type $I^{166}$ have been suggested to contribute significantly to the calcification process.

Several lines of evidence seriously challenge the view that atherosclerotic calcification is a degenerative process, resulting from a mere passive precipitation of calcium salts. ${ }^{167}$ It has been shown, for instance, that the atherosclerotic plaque is associated with the same proteins and ultrastructural components as in bone tissue. Atherosclerotic calcifications are occasionally even described as real ossifications with several morphological and histological similarities to bone. ${ }^{171.572}$ Biochemical and $\mathrm{X}$-ray diffraction studies have confirmed that the mineral phase in the plaque consists of hydroxyapatite, similar to that found in bone. ${ }^{17,174}$ Further support comes from studies which have shown that several bone-associated proteins are present in the atherosclerotic lesions. These include type I collagen which is predominantly found in bone, whereas normal aortic tissue contains collagen type III, ${ }^{175}$ osteopontin ${ }^{176}$ and osteonectin. ${ }^{177}$ Of interest are the reports that a potent osteogenic differentiation factor, bone morphogenetic protein-2a (BMP2a), ${ }^{178}$ is present in human atherosclerotic plaque and that cells isolated from the intimal artery wall are able to produce this growth factor in vitro. Furthermore, these cells have osteoblast like properties: they are able to produce and secrete alkaline phosphatase, collagen type I, osteocalcin, osteonectin and osteopontin and can also form multicellular nodules which undergo spontaneous hydroxyapatite calcification. Of particular interest is that the rate of mineralization of these nodules can be induced by two abundant constituents of the plaque: TGF- $\beta 1$ and 25 -hydroxycholesterol. ${ }^{17 \%}$ Based on these findings it can be hypothesized that certain stimuli in the vessel wall can induce the expression of BMP2a, leading to osteogenic differentiation of certain cells present 
in the intima. These osteoblast-like cells are able to produce several (Gla-containing) bone matrix proteins as well as hydroxyapatite mineral. According to this view, vessel wall calcification must be regarded as an active, highly regulated process, similar to osteogenesis. ${ }^{180.179,181}$

\section{Gla-proteins and atherosclerotic calcifications}

Soon after the initial report in 1975 that Gla is present in bone tissue, ${ }^{30}$ it was also identified in several sites of ectopic calcifications, such as calcium containing skin exudates, calciumcontaining renal stones and the calcified atherosclerotic plaque ${ }^{31.37 .36}$ The amount of Gla in atherosclerotic calcifications has been shown to be especially associated with the mineralized parts of the atherosclerotic lesions and to be associated with disease activity ${ }^{37.182}$ A considerable amount of Gla, up to $60 \%$ of that found in bone, is present in the calcified atherosclerotic plaque. ${ }^{31}$ Only up to $20 \%$ of the total Gla present seems to be extractable by EDTA demineralization, suggesting a tight association of the majority of the Glaproteins with the non-mineralized extracellular matrix. Since 1976, several Glaproteins have been reported in calcified atherosclerotic lesions. The reported molecular weights vary widely: $6-10,{ }^{183,384,185} 80 \mathrm{kDa},{ }^{182}$ or $23 \mathrm{kDa} .^{38}$ Some of these Gla-proteins appear to be similar to osteocalcin, ${ }^{31,183.184}$ whereas others are apparently an artifact of the isolation procedure (atherocalcin, $80 \mathrm{kDa}$ ). ${ }^{186}$ Osteocalcin has been found in trace amounts in the calcified plaques and accounts only for a small fraction of the total Gla levels present. ${ }^{182.184 .186}$ Although several in vitro studies suggest that osteocalcin can be produced by cells from the (atherosclerotic) vessel wall, ${ }^{179.187}$ osteocalcin mRNA levels have not yet been detected in the plaque or vessel wall. The indications that osteocalcin accounts for only a small fraction of the total Gla $(0.05 \%)$, ${ }^{184}$ make it less probable that it is locally produced in the atherosclerotic lesions. Based on the presently available data, the possibility that osteocalcin present in the plaque is absorbed from the blood stream cannot be excluded. Recently, mRNA, as well as protein levels of a known Gla-protein have been identified in the human atherosclerotic plaque: namely MGP. ${ }^{1 *}$ MGP mRNA levels were detected in vascular smooth muscle cells and macrophages, especially associated with the lipid-rich calcifying regions. Of interest is that in the human calcified plaque, MGP is localized in matrix vesicles, similar to the situation found in bone tissue. ${ }^{189}$ MGP has already been detected in the vessel wall, but it is the first Gla-protein for which a local production in the calcified atherosclerotic plaque has been established.

The role of vascular Gla-proteins is still unknown. In vitro studies show that osteocalcin as well as MGP, are potent inhibitors of hydroxyapatite forma- 
tion. ${ }^{31.121}$ Also other, as yet unknown, Gla-proteins in the calcified plaque have been shown to strongly inhibit precipitation of calcium salts from supersaturated solutions. ${ }^{190}$ Osteocalcin is known to have chemotactic properties towards macrophages, monocytes and osteoclasts. ${ }^{18.190120}$ Since macrophages have an important role in the pathogenesis of the plaque, ${ }^{164}$ it is conceivable that osteocalcin may have a mediating role in the migration of these cells towards the plaque. The recent detection of abundant levels of MGP in the calcified plaque, and its localization in matrix vesicles similar to that in areas of enchondral bone formation, makes it tempting to hypothesize that its function may be similar to that in the cartilage growth plate of the rapidly growing fetus: ${ }^{121}$ it may act as a local mineralization inlibitor, preventing or retarding the calcification process in the plaque.

\subsection{INTRODUCTION TO THIS THESIS}

Using the extra-hepatic Gla-protein osteocalcin, our group has previously found that postmenopausal women may have a marginal vitamin $\mathrm{K}$-status. ${ }^{89}$ This subnormal vitamin $\mathrm{K}$-status is mainly apparent in extra-hepatic tissues. It is not known whether the prolonged presence of a marginal vitamin $\mathrm{K}$-status has pathological consequences. Preliminary data suggests, that a poor vitamin K-status may affect calcium metabolism. ${ }^{154.89}$ Both in bone and in calcified atheroselerotic plaques Gla-proteins have been detected. These Gla-proteins may have a regulatory role in the mineralization processes both in bone and the calcified atherosclerotic plaque.

In the thesis we have investigated the latter hypothesis in several ways. Using the extra-hepatic Gla-protein osteocalcin as a marker for vitamin K-status, we have measured how the vitamin $\mathrm{K}$-status is related to various markers for calcium metabolism by performing vitamin $K$ supplementation studies with phylloquinone. Secondly, the association of vitamin K-status with the presence of atherosclerotic calcifications in the abdominal vessel wall and bone mass was investigated in a population-based study. Finally, we have attempted to isolate Gla-proteins which are present in the calcified atherosclerotic plaque. 


\section{REFERENCES}

1. Dam H. Cholesterinstoffwechsel in Hünereiern un Hünchen. Biochem Zeitschr 1929;215:475. 92.

2. Dam H. The antihaenorrhagic vitamin of the chick. Biochen 1 1935;29:1273-85.

3. Shofield FW. Can Ver Rec 1922;3:74-9.

4. Campbell MA, Link KP. Haemorrhagic disease in cattle. J Biol Chem 1941:18:21-33

5. Hirsch d, Fuster V. Guide to anticougulant therapy part 2: oral anticoagulants. Circulation $1994: 89: 1469-80$.

6. Hadler MR, Shadbolt RS. Novel 4-hydroxycoumarin anticoagulants active against resistant rats. Nature 1975;253:275-7.

7. Hemker HC, Velikamp JI, Hensen A, Loeliger EA. Nature of prothrombin biosynthesis: preprothrombinaemia in vitamin K-deftciency. Narure 1963;200:589-90.

8. Ganrot PO, Nilehn JE. Plasma prothrombin during treatment with dicumarol. II. Demonstration of an abnormal prothrombin fraction. Scand J Clin Lab lnvest 1968;22:23-8.

9. Stenflo $\mathbb{~}$. Dicumarol-induced protlarombin in bovine plasma. Acta Chem Scand 1970:24:37623

10. Hemker HC, Velkamp JJ, Loeliger EA. Kinetic aspects of the interaction of blood cloting enzymes. Thromb Diathes Haemorrh 1968:19:346-63.

1. S. Stenflo J; Fernlund P. Egan W, Roepstorf P. Vitamin K-dependent nodifications of glutamic acid residues in prothrombin. Proc Natl Acad Sci USA 1974;71:2730-33.

12. Furie B, Furie BC. Molecular basis of vitamin K-dependent $\gamma$-carboxylation. Blood $1990: 75: 1753-62$.

13. Vermeer C. $\gamma$ Carboxyglutamate-containing proteins and the vitamin K-dependent carboxylase. Biochem J 1990:266:625-36.

14. Fasco MJ, Hildebrandt EF, Suttie JW. Evidence that warfarin anticoagulant action involves wo distinct reductase activities. J Biol Chem 1982;257:11210-2.

15. Hildebrandt EF, Sutie JW. Mechanism of coumarin action: sensitivity of vitamin K metabolizing enzymes of normal and warfarin-resistant rat liver. Biochemistry 1982;21:2406-11.

16. Ulich MMW. Knapen MHJ, Hermann-Erlee MPM. Vermeer $C$. Vitamin $K$ is no antagonist for the action of warfarin in tat osteosarcoma UMR 106. Thromb Res 1988;50:27-32.

17. Price PA. Willatmson MK. ENects of wartarin on bone: studies on the vitamin K-dependent bone protein of rat bone. J Biol Chem 1981:256:12754-9

18. Price PA. Kaneda $Y$. Vitanin $K$ conteracts the effect of warfarin in liver but not in bone. Thromb Res 1987:46:121-31.

19. van Haartem LJM, Knapen MHU, Hamulyák K. Vermeer C. Circulating osteocallcin during orat anticoagulant therapy. Thromb Haemostas $1988 ; 60: 79-82$.

20. Ulrich MMW, Furie B, Jacobs MR, Vermeer C, Furie BC. Vitamin K-dependent carboxylarion: a synthetic peptide based upon the ganma-carboxylation recognition site sequence of the prothrombin propeptide is an active substrate for the carboxylase in vitro. I Biol Chem 1988:263:9697-702.

21. Price PA. Fraser JD, Metz-Vinca G. Molecular cloning of matrix Gla protein: implications for substrate recognition by the vitamin K-dependent gamma-carboxylase. Proc Natl Acad Sci USA 1988;84:8335-9.

22. Esmon CT, Sadowski JA. Surtie JW. A new carboxylation reaction. The vitamin K-dependent incorperation of $\mathrm{H}^{14} \mathrm{CO}_{3}$ into promrombin. J Biol Chem 1975:250:4744-8.

23. Lian JB. Friedman PA. The vicamin K-dependent synthesis of gamma-carboxyglutamic acid by bone microsomes. J Biol Chem 1978;253:6623-6. 
24. Hauschka PV, Friednan PA, Traverso HP, Gallop PM. Viramin Kadependent ganmmanarboxyglutamatio acid formation by kidney microsomes in witro. Biochem Biophys Res Commun 1976:71: 1207-13.

25. de Boer-wan den Berg MAG, Verstijnen CPM., Vermeer C. Vilamin K-dependent carboxylase in skin. IInvest Dermatol 1986:87:377-80.

26. Buchthal $\mathrm{SD}$, Bell $\mathrm{RG}$. Vitamin $\mathrm{K}$ depentent carboxylation of glutamic residues to gamma-carboxyglutamate in microsomes from spleen and testes: comparison with liver, lung, and kidney. Biochemistry 1983;22:1077-82.

27. Vermeer $\mathrm{C}$, Hendrix $\mathrm{H}$, Daemen $M$. Vitamin $\mathrm{K}$-dependent carboxylases from non-hepatic tissues. FEBS Lett 1982;148:317-20.

28. van Hatarlen, LJM, Ulrich MM, Hemker HC, Soute BAM, Vermeer C. Isolation and partial characterization of a vitamin $\mathrm{K}$-dependent carboxylase from bovine aortac. Biochem J $1987: 245: 251-5$.

29. de Boer-van den Berg MAG, Uitendaal MP, Vermeer C. Direct measurement of vitamin $K_{\text {- }}$ dependent enzynes in various isolated and cultured tumor and non-tumor cells. Mol Cell Biochem 1987;5:71-76.

30. Hauschka PV, Lian JB, Gallop PM. Direct identification of the calcium-binding amino acid. $\gamma-$ carboxyglutamate, in mineralized tissue. Proc Nat Acad Sci 1975;72:3925-9.

31. Price PA, Otsuka AS. Poser JW, Kristaponis J. Raman N Characterization of a $\gamma$-carboxyglutamic acid-containing protein from bone. Proc Nall Acad Sci USA 1976;73:1447-51.

32. Price PA, Urist MR, Otawara $Y$. Matrix Gla protein, at new $\gamma$-carboxyglutamic acid-containing protein which is associated with the organic matrix of bone. Biochem Biophys Res Comm 1983;117:765-71.

33. Di Scipio RG. Hermodson MA, Yates SG, Davie EW. A comparison of human prohrombin, factor IX (Christmas factor), factor $X$ (Stuart factor), and protein $S$. Biochenistry 1977:16:698-706.

34. Maillard $C$, Berruyer $M$, Serre $C M$, Dechavanne $M$, Delmas PD. Protein-S, a vitamin $K$ dependent protein, is a bone matrix component synthesized and secreted by osteoblasts. Endocrinology $1992 ; 130: 1599-1604$.

35. Linde A, Bhown M, Cothran WC, Hoglund A. Butler WT. Evidence for several ganmacarboxyglutamic acid-containing proteins in dentin. Biochim Biophys Acta 1982:704:235-9.

36. Lian JB. Prien EL Jr, Glimcher MJ. Gatlop PM. The presente of protein-bound y-carboxyglutamic acid in calcium-containing renal calculi, J Clin Invest 1977;59:1151.7.

37. Lian JB, Skinner M, Glimcher MJ, Gallop $\mathbb{P}$. The presence of $\gamma$-Carboxyglewamic acid in proteins associated with ectopic calcification. Biochem Bioph Res Comm 1976;73:349.55.

38. Gijsbers BMLG, van Haarlem LJM. Soure BAM, Ebberink RHM, Vermeer C. Characteriz. ation of a Gla-conaining protein from calctied human atherosclerotic plaques. Arterioscterosis $1990 ; 10 ; 991-5$

39. Hamilon SE, King $G$, Tesch D, Riddles PW, Keough $D T$, Jell 1 , Zerner $B$. gamma-Carboxy. glutamic acid in invertebrates: its identification in hermatypic corals. Biochem Biophyd Res Commun 1982;108:610-3.

40. Soute BAM, Muller-Esterl W, de Boer-van den Berg MA. Ulrich M, Vermeer C. Discovery of a gamma-carboxyglutamic acid-containing protein in human spermatozoa. FEBBS let $1985 ; 190: 137-41$.

41. Tans $G$, Rovers-Riemslag JW, wan Rijn JL, Rosing I. Purfication and properties of a prothrombin activator from the venom of Notechis scutalus scutatus. I Biol Chem $1985: 260: 9366-72$.

42. Speijer $\mathrm{H}$, Govers-Riemslag JW, Zwaal RF, Rosing I. Prothrombin activation by an activator from the venom of Oxyuranus scutellatus. I Biol Chem 1986-261:13258-67. 
43. Nakagawa $\mathrm{Y}$, Abram $\mathrm{V}$, Coe FL Isolation of calcium oxalate crystal growth inhibitor from rat kidney and urine. Am I Physiol 1984:247:F765-72.

44. Mchnosh JM, Olvera BM, Cruz LJ, Gray WR. Gamma-carboxygluamate in a neuroactive toxin. I Biol Chem 1984:259:14343-6.

45. Manfioletti $G$, Brancolini $\mathrm{C}$, Avanzi $\mathrm{G}$, Schneider $\mathrm{C}$. The protein encoded by a growth arrestspecific gene (gas-6) is a member of the vitamin $K$-dependent proteins related to protein $S$, a negative coregulator in the blood coagulation cascade. Moll Cell Biol 1993:13:4976-85.

46. Rizl $V F$. Biosynhetische veranderungen von tritium-markiertem vitamin $K_{3}$ in menschen. Alomkernenergie 1970;15:162-6.

47. Mexiek JA, Settlemire, CT, Brierly GP et al. Erythrocyte membrane interactions with menadionee and the mecthanism of meradione-induced hemolysis. Biochem Biophys Acta $1970 ; 219: 361-71$

48. Allison AC. Danger of witamin $K$ to newborn. Lancet 1955; 1:669.

49. Meyer TC, Angus J. The effect of large doses of "synkavi" in the newborn. Arch Dis Child $1956 ; 31: 213-15$.

50. Richardson LR, Wilkes $S$, Ritchey SI. Comparative vitamin $K$ activity of frozen, irradiated and heat-processed foods. Nutr 1962:73;369.

5!. Laugenberg JP, Tjaden UR, Vogel de EM, Langerak D. Devermination of vitamin K (vitamin $\mathrm{K}_{1}$ ) in raw and processed vegetables using reversed phase HPLC with electroftuorometric detection. Acta Alimentaria 1986;15:187-98.

52. Shearer MJ, Allan V, Haroon $Y$, Barkhan $P$. Nutritional aspects of vitamin $K$ in the human. In: Vitamin $\mathrm{K}$ metabolism and vitamin K-dependent proteins. Suttie JW, Ed. Univ. Park Press, Baltimore 1980;317-27.

53. Booth SL. Sadowski JA, Weihrauch IL, Ferland G. Vitamin $\mathrm{K}_{1}$ (pliylloquinone) content of foods: a provisional lable. J Food Composition Analysis 1993;6:109-20.

54. Sakano T, Notsumoto S, Nagaoka T. Morimoto A, Fujimoto K, et al. Measurement of K vitamins in food by high-performance liquid chromatography with fluorometric detection. Vitamins (Japan) 1988:62:393-8.

55. Hirauchi $K$, Sakano T, Notsumoto S, Nagaka T, Morimoto A, et al. Measurement of $K$ vitamins in food by thigh-performance liquid chromatography with fluorometric detection. Vitandins (Japan) 1989:63:147-51.

56. Shearer MJ, von Kries R. Saupe J. Comparative aspects of human vitamin $\mathrm{K}$ metabolisn and mutriture. J Nutr Sci Vit 1992;S-133;413-6.

57. Romatar $\mathrm{K}$. Conly IM, Chubb H. Louie TJ. Production of menaquinones by intestinal anterobes. I Infect Dis 1984:150:213-18

58. Uchida $\mathrm{K}$, Komero $\mathrm{T}$. Relationship between dietary and intestinal vitamin $\mathrm{K}$, clotting factors levels, plasma vitamin $K$, and urinary Gla. In: Current advances in vitamin $K$ research. Suttie IW. Ed. Elsevier. New York 1988;477-92.

59. Vermeer C, Hamulyák K. Pathofysiology of Vitamin K-deficiency and oral anticoagulants. Thromb Ham 1991;66:153-9.

60. Groenen-van Dooren MCL, Soute BAM, Jie K-SG, Thijssen HHW, Vermeer C. The relative effects of phylloquinone and menaquinone on the blood coagulation factor synthesis in vitamine K-deficient rats. Biochem Pharmacol 1993;46:433-7.

61. Conly JM. Stein K. Quantative and Qualitative measurements of K vitamins in human intestiwal contents. Am J Gastroenter 1992;87:311-6.

62. Olson RE. The function and metabolism of vitamin K. Ann Rev Nutr 1984:4281-337.

63. Shearer MJ. Vitamin K metabolism and nutriture. Blood Reviews 1992;6:92-104

64. Shearer MJ. McBurney A, Barkhan P. studies on the absorption and metabolism of phylloquinone (vitamin $K_{0}$ ) in man. Vitamins and Hormones 1974;32.513-42. 
65. Hollander D, Muralidara $K S$. Rin S. Colonic absorption of bacterially synthesezed vitamin $\mathrm{K}_{2}$ in the rat. Am I Plyysiol 1976;230:251-255

66. Savage D, Lindenbaum J. Clinical and experimental human vitamin $K$-deficiency. In: Lindenbaum J. editor. Nutrition in hematology. New York: Livingstone, 1983:271-320.

67. Sadowski JA. Hood SJ, Dallal GE, Garry PJ. Phylloquinone in plasma from elderly and young adults: factors influencing its concartration. Am J Clin Nurr 1989:50:100-8.

68. Shearer MJ, McCarthy PT "Crampton OE, Mancok MB. The assessment of human vitamin Kstatus from tissue measurements. In: Current advances in vitamin $K$ research. Sutte IW. Ed. Elsevier. New York 1988:437-52.

69. Saupe J. Shearer MJ, Kohlmeier M. Phylloqumone transport and its influence on qu-carboxy* glutamate residues of osteocalcin in patients on matntenance hemodialysis. Am J Clin Nutr 1993:58:204-8.

70. Surtie JW, Mummah-Schenkel LL, Shal DV, Lyle BI. Greger IL. Viramin K deficiency from dietary vitamin K restriction in humans. Am J Clin Nutr 1988:47:475-80.

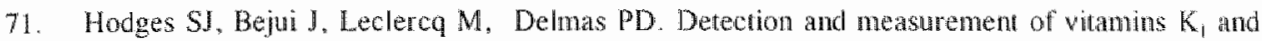
$\mathrm{K}_{2}$ in human cortical and rabecular bone. I Bone Miner Res 1993:8:1005-8.

72. Olson IA. Recommended dietary intakes (RD) of witamin $\mathrm{K}$ in humans. Am J Clin Nutr $1987 ; 45: 687-92$.

73. Widdershoven J, Munster wan P, De Abreu R, et al. Four methods compared for measuring des-carboxy-prothrombin (PIVKA-II). Clin Chem 1987,33:2074-8.

74. won Kries R, Greer FR, Suttie JW. Assessment of vitamin $\mathbb{K}$ status of the newborn infant. Pediat Gastroen Nuir 1993;16:232-8.

75. Suttie JW, Mummah-Schenkel LL, Shah DV, Lyle BJ, Greger IL. Vitamin K deficiency from dietary vitamin $\mathrm{K}$ restriction in humans. Am J Clin Nutr 1988;47:475-80.

76. Ferland G, Sadowski $\mathrm{J} A, O^{\prime} B$ rien $M E$. dietary induced subclinical vitamin $K$ deficiency in normal human subjects. J Clin lvest 1993;9:1761-8.

77. Blanchard RA, Furie BC, Barnett J. Vitamin $\mathrm{K}$ deficiency in newborns and their Mothers. Thromb Faem 1985;54:1340.

78. Blanchard RA, Furie BC, Jorgensen M, Kruger SF, Furie B. Acquired vitamin K-dependent carboxylation deficiency in liver disease. New Eng J Med 1981;305:242 8 .

79. Okuda H. Nakanishi T. Furukawa M. Obata H. Vitamin K-dependent proteins and hepatocel lular carcinoma. J Gastroent Hep 199:;6:392-9.

80. Thierry MJ, Suttie JW. Effect of warfarin and the choro anallog of vitamin $\mathbb{K} I$ on phylloquinone metabolism. Arch Biochem Biophys $1971 ; 147,430 \times 5$.

81. Kindberg $C G$. Suttie JW. Effect of various indakes of phyloquinone on signs of witamin $K$. deficiency and serun and liver phylloquinone concentrations in the rat. J Nutr 1989:119:175 80 .

82. Hauschka PV. Lian JB. Cole DEC. Gundberg CM. Osteocalcin and Matrix Gla Protein: vitamin K-dependent proteins in bone. Plys Rev 1989;69:990-1047.

83. Power MJ, Forrell PF. Osteocalcin: diagnostic methods and clinical applications. Crit Rev Clin Lab Sci 1991:2:27-335.

84. Soute BAM, Ulrich MMW, Knapen MHI, van Haarlem LJM. Vermeer C. The quantification of gammacarboxyglutamic acid residues in plasma-osteocalcin. Calcif Tissue Int 1988:43:18482.

85. Torres R, de la Piedra C, Rapado A. Binding of serum osteocalcin to hydroxyapatite in Pagel's disease of bone. Bone Miner 1991;14:55-65.

86. Price PA, Williamson MK, Lothringer JW. Origin of the vitamin K-dependent bone protein found in plasma and its clearance by kidney and bone. I Biol Chem 1981:256:12760-6. 
87. Menon RK, Gill DS. Thomas M. Kernoff PB, Dandona P. Impaired carboxylation of osteocalcin in warfarin-treated patients. J Clin Endocrinol Metab 1987;64:59-61.

88. Pietschmann P. Woloszczuk W. Panzer $\$$, Kyrle P. Smolen J. Decreased serum osteocalcin levels in phenprocoumon-treated patiens. J Clin Endocrin Metab 1988;66:1071-4.

89. Knapen MHJ, Hanulyák K. Vemeer $\mathrm{C}$. The effect of vitamin $\mathrm{K}$ supplementation on circulating osteocalcin (bonic Gla-protent) and urinary calcium excretion. Ann Int Med 1989; 111 : $1001-5$.

90. Merle B, Delmas PD. Normal carboxylation of circulating asteocalcin (bone Gla-protein) in Paget"s disease of bone. Bone Miner 1990:11:237-45.

91. Plantalech $L$, Guillaumont $M$, Vergnaud $P$, Leclercq $M$, Delmas $P D$. Impairment of gamma carboxylation of circulating osteocalcin (bone Gla protein) in elderly women. J Bone Miner Res 1991:6:1211-6.

92. Szulc P. Chapuy MC. Meunier PJ, Delmas PD. Serum undercarboxylated osteocalcin is a marker of the risk of hip fracture in elderly women. J Clin Invest 1993;91:1769-74.

93. Ferland $\mathrm{G}$, Sadowski JA, O'Brien ME. Dietary induced subclinical vitamin $\mathrm{K}$ deficiency in normal human subjects. J Clin Invest 1993;9:1761-8.

94. Price PA. Vitamin $K$ nutrition and postmenopausal osteoporosis [Editorial]. I Clin Invest $1993 ; 91: 1269$

95. Hauschka PV, Carr SA. Calcium-dependent a-helical structure in osteocalcin. Biochemistry $1982 ; 21: 253847$

96. Price $P A$, Baukol $S A, 1,25$ Dihydroxyvitamin $D_{3}$ increases synthesis of the vitamin $K$-dependent bone protein by osteasarcoma cells. I Biol Chem 1980,255:11.660-7.

97. Kruse K. Kracht U. Evaluation of serum osteocalcin as an index of altered bone metabolism. Eur J Pediatr 1986; 145:27-33.

98. Obrant KJ, Bengner U, Delmas PD. Bone Gla: protein in blood derived directly from human bone tissue. Calcif Tissue Int 1989:44:296-97.

99. Farrugia W, Melik RA. Metabolism of osteocalcin. Calcif Tissue Int 1986;39:234-8.

100. Malluche HH, Fatgere M-C, Fanti P, Price P. Plasma levels of bone Gla-protein reflect bone formation in patients on chronic maintenance dialysis. Kidhey lnt 1984:26:869-74.

101. Brown JP. Delmas PD, Malaval L. Edouard C, Chapuy MC, Meunier PI. Serum bone Glaprotein: a speciffic marker for bone formation in postmenopausal osteoporosis. Lance 1984;i:1091-3.

102. Delmas PD. Malaval I. Artot ME, Meunier PJ. Serum bone gla protein compared to bone histomorphometry in endocrine diseases. Bone 1985:6:339-41

103. Slovik DM. Gundberg CM. Neer RM, Lian JB. Chinicall evaluation of bone turnover by serum asteocalcin measurements in a hospital setting. I Clin Endocr Metab 1984:59:228-30.

104. Duda RJ . O'Brien JF. Katzmann JA, Peterson JM, Mann KG. Riggs BL. Concurrent assays of circulating bone gla-protein and one alkaline phosphatase: effects of sex, age and metabolic
bone disease. J Clin Endocrin Metab 1988:66:951-7.

105. Parthemore JG. Burton DW. Deftos Lf. Associations and dissociations between serum bone Gla protein and alkaline phosphatase in skeletal metabolism. J Orthop Res 1993;11:67:-6. 106. Price PA. Nishimow SK. RIA for the vitamin K-dependent protein of bone and its discovery
in plasma. Proc Natl Acad Sci USA $1980 ; 77: 2234-8$

107. Kao PC. Riggs BL, Schryver PG. Development and evaluation of an osteocalcin chemiluminoimmunoassay. Clin Chem 1993:39:1369-74.

108. Gamero P. Grineatux M, Demuaux B. Preaudar C. Seguin P. Delmas PD. Measurement of serum osteocalcin with a human-specific two-site immunoradiometric assay. J Bone Min Res
1992, 12:1389-98. 
109. Hosoda K, Egushi H. Nakamoto T. at al. Sandwich immunoassay for intace human osteocallin. Clin Chem 1992:38:2233-8.

110. Delmas PD, Christiansen C. Mam KG. Price PA. Bone Gla Protein (Osteoentein) assay standardization report. J Bone Miner Res 1990:5:5-11.

111. Masters PW, Jones RG. Purves DA, Cooper EH, Cooney IM. Conmercial assays for serum osteocalcin give clinically disconcordant results. Clin Chem 1994:40:358-63.

112. Gundberg C, Weinsten RS. Multiple immunoreactive forms in uremic serum. I Clin Invest $1986: 77: 1762-7$.

113. Taylor AK, Linkhart S, Mohan S, Mohan S, Christenson RA, Singer FR, Baylink DJ. Multiple osteocalcin fragments in human urine and serum by a midmolecule osteocalcin radiommunoassay. J Clin Endocr Metab 1990; 70:467-72.

1.14. Power MJ, Gosling JP. Fotrell PF. Radioimmunoassay of osteocalcin with polyclonal and monoclonal antibodies. Clin Chem 1989;35: 1408-15.

115. Minisola S, Carnevale V. Pacitti MT, Romagnoli E, Scarnecchia L. Rosso R, Minisola G. Mazzuoli GF. Serum osteocalcin in metabolic diseases: what is its real signifucance? J Endocrin Invest $1993: 16: 277-9$.

116. Garnero P. Grimeaux M, Seguin P. Delmas PD. Characterization of immunoreactive forms of human osteocalcin generated in vivo and in vitro. J Bone Miner Res 1994:9:255-64.

117. van de Loo PGF, Soute BAM, van Haarlem IJM, Vermeer C. The effect of gla-containing proteins on the precipitation of insoluble salts. Biochem Biophys Res Comm 1987;142:113-9.

118. Glowacki J, Lian JB. Impaired recruiment and differentiation of osteoclast progenitors by osteocalcin-deplete bone implants. Cell Differ 1987:21:247-54.

119. Glowacki J, Rey C. Glincher MJ. Cos KA, Lian JB. A role for osteocalcin in osteoclast differentiation. J Cell Biochem 1991;45:292-302.

120. Lian JB. Osteocalcin: functional studies and postulated role in bone resorption. In: Suttie JW, editor. Current Advances in Vitamin K Research. New York: Elsevier North Holland, 1988 : 245-57.

121. Hale JE, Fraser JD, Price P. The iclentification of matrix Gla protein in carrilage. I Biol Chem $1988 ; 263: 582044$

122. Fraser JD. Price PA. Lung. heart and kidney express high levels of mRNA for the vitamin $K$ dependent matrix Gla protein. I Biol Chem 1988:263:11033-6.

123. Fraser JD, Otawara $Y$, Price PA. 1.25-Dihydroxyvitamin $D_{3}$ somulates the synthesis of Matrix y-Carboxyglutamic acid Protem by osteosarcoma cells. I Biol Chem 1988:263:911-6.

124. Cancela ML, Price PA. Retinoic acid induces matrix Glit protein gene expression in human cells. Endocrinology 1992:130:102-8.

125. Otawara $Y$. Price P. Developmental appearence of matrix GLA protein during calcification in the rat. I Biol Chem 1986:261:10828-32.

126. Hessing $\mathrm{M}$. The interaction between complement component $\mathrm{C} 4 \mathrm{~b}$-binding protein and the vitamin $\mathrm{K}$-dependent protein $S$ forms a link between blood coagulation and the complement system. Biochem J 1 191:227:58192.

127. Pan E, Gomperts ED, Millen R, Gilsanz V. Bone mineral density and its association with inherited protein $S$ deficiency. Thromb Res 1990;58:221-31.

128. Maillard C. Berruyer M. Serre CM. Amiral J. Dechavarne M, Delmas PD. Thrombomodulin is synthesized by osteoblasts, stimulated by $1,25-(\mathrm{OH})_{2} \mathrm{D}_{3}$ and activates protein $\mathrm{C}$ at their cell membrane. Endocrinology 1993:133:668-74.

129. Hall JG. Pauli RM. Wilson KM. Maternal and fetal sequelae of anticoagulation during pregnancy. Am J Med 1980;68:122-40. 
130. Paul RM, Lian MB Mosher DF, Suttie JW. Association of congental deficiency of multiple vitamin $K$-dependent coagulation factors and the phenoype of the warfarin embryopathy: clues to the mechanism of teratogenicity of coumarin derivatives. Am 3 Hum Genet 1987:4:566-83.

131. Piro LD. Whyle MP. Murphy WA. Brge SJ. Normal cortical bone mass in patients after long term coumiadin therapy. J Clin Endocrinol Metab 1982:54:470-3.

132. van der Linden T, Howvenagel E, Graux $P$ et al. Retentissement sur le metabolisme osseux des tratitements au long cours par les antivitamines K1. Ann Cardiol Angeiol Paris 1991;40:405-7.

133. Rosen HN, Maitland LA. Suttie JW, Manning WJ. Glynn RJ, Greenspan SL. Vitamin K and maintenance of skeletal iniegrity in adults. Am I Med 1993;94:62-8.

134. Fiore $C E$, Tamburino $C$, Foti $R$, Grimaldi $D$. Reduced bone mineral content in patients taking an oral anticoagulant. Souh Med I 1990;83:538-42.

135. Resch $H$, Pietschmann $P$, Krexner $\mathbb{E}$, Willvonseder $R$. Decreased peripheral bone mineral content in pattents under anticoagulant therapy with phenprocoumon. Eur Heart J 1991:12:439. 41.

1136. Howe AM. Webster WS. The warfarin embryopathy: a rat model showing maxillonasal hypoplasid and other skeletal disturbances. Teratology 1992:46:379-90.

137. Hauschka PV, Reid ML. Vitamin $K$ dependence of a calcium-binding protein containing gammacarboxygltutamic acid in chicken bone. J Biol Chem 1978;253:9063-8.

138. Lavelle PA, Lloyd QP, Gay CV, Leach RM Jr. Vitamin K deficiency does not functionally impair skeletal metabolism of laying hens and their progeny. J Nutr 1994:124:371-7.

139. Fetein R. Tassinari MS, Lian JB. Effect of sodium warfarm on vitamin K-dependent proteins and skeletal development in the rat fetus. J Bone Miner Res 1990;5:885-94.

140. Price PA, Epstein DJ, Lothringer JW. Nishimoto SK, Poser JW, Williamson MK. Structure and function of the vitamin $K$-dependent protein of bone. In: Suttie JW, editor. Vitamin $K$ metabolism and witamin $\mathrm{K}$-dependent proteins. Proceedings of the $8^{\text {ti }}$ Steenbock Symposium; 1979:219-26.

141. Price PA, Williamson MK, Haba T, Dell RB, Jee WS. Excessive mneralization with growth plate closure in rats on chronic warfarin treatment. Proc Natl Acad Sci USA 1982;79:7734-8.

142. Pastoureau P, Vergnaud P. Meunier PJ "Delmas PD. Osteopenia and bone-remodelling abnormalities in warfarin-treated lambs. J Bone Miner Res 1993;8:1417-26.

143. Akedo $Y$, Hosoi T, Inoue S, Ikegami A, Mizuno $Y$, Kaneki M, Nakamura T, Ouchi $Y$, Orimo H. Vitamin $K_{2}$ modulates proliferation and function of osteoblastic cells in viro. Biochem Bioplys Res Commun 1992;187:814-20.

144. Koshihara $Y$. Hoshi $K$. Shiraki M. Enhancement of mineralization in human osteoblast-like cells by vitamin $K_{2}$ (menatetrenone) I Bone Min Res 1992;7:5209.

44.5. Rober D. Jorgetti V. Lacour B. Leclerg M. Cournot-Wimer G. Uhan A. Drüeke T. Hypercaleiuria during experimenoal vilamin $K$ deficiency in the rat. Calcif Tissue Int

146. Akiyitha $Y$. Hara $K$. Ohkawa I. Tajima T. Effects of menatetrenone on bone loss induced by
owariectomy in rats. Jaipan J Pharmacol $1993.62 \cdot 145-153$.

147. Hata K. Akiyama Y. Ohkawa 1, Tajima T. Effects of menatetrenone on prednisolone-induced bone loss in rats. Bone 1993:14:813-8.

148. Koshihara $Y$, Hoshi $K$. Shiraki $M$. Vitamin $K_{2}$ (menatetrenone) inhibios prostaglandin synthesis in cultured human osteoblast-like periosteal cells by inhibiting prostaglandin H synthase
activity. Biochem Phatmacol 1993:46:1355-62. 149. Hara K. Akiyana Y, Tajima T. Shiraki M. Menatetrenone inhibits bone resorption parily
through inhbition of PGE, synhesis in virro. I Bone Miner Res 1993;8:535-42. 
150. Hodges SJ, Pilkington MI, Shearer MJ, Bitensky L. Chayen J. Age-related changes in the circulating levels of congeners of vitamin $K_{2}$, menaquinone- 7 and menaquinone- 8 . Clin Sci $1990 ; 78-63-6$.

151. Hart JP, Catteral A, Dodds RA. Klenerman L. Shearer MJ, Bitensky L. Chayen I. Circulating vitamin $K_{1}$ levels in fractured neck of femur. Lancell 1984: it:283.

152. Hart JP, Shearer MJ, Klenerman L, Catteral A. Reeve J, Sambrook PN, Dodds RA, Bitensky $L$, Chayen $J$. Electrochemical detection of depressed circulating levels of vitanin $K l$ in osteoporosis. J Clin Endocrin Metab 1985;60:1268-9.

153. Hodges SJ. Akesson K, Vergnaud P, Obrant K. Dellmas PD. Circulating levels of vitanins $K$, and $K_{2}$ decreased in elderly women with hip fracture. J Bone Miner Res 1993:8:1241-5.

154. Tomita A. Postmenopausal osteoporosis ${ }^{47} \mathrm{Ca}$ study with vitamin $\mathrm{K}_{2}$. Chin Endocrin $1971 ; 19: 731-6$.

155. Szulc P, Chapuy MC, Meunier PJ, Delmas PD. Serum undercarboxylated osteocalcín is at marker of the risk of hip fracture in elderly women. J Clin lnvesi 1993:91:1769-74.

156. Akiba T. Kurihara S. Tachibana $K$. Kuwahara M, Sakamoto H, Yoneshima H. Marumo F. Vitamin $K(K)$ increased bone mass (BM) in hemodialysis patients ( $P$ ts) with low-turnover bone disease (LTOBD). J Am Soc Nephrol 1991:2:608.

157. Orimo $H$, Fujita $T$, Onomura $\mathbb{T}$, Inoue $\mathbb{T}$, Kushida $\mathbb{K}$, Shiraki $M$. Clinical evaluation of Ea0167 (menatetrenone) in the treatment of osteoporosis. Clin Eval (Japanese) 1992:20:45-100.

158. Golding J, Greenwood R. Birmingham K, Mott $\mathrm{M}$. Childhood cancer, intramuscular vitamin $\mathrm{K}$, and pethidine given during labour. Brit Med J 1992;305:341-6.

159. Ekelund H. Fimström $\mathrm{O}_{n}$ Gunnarskog J, Källén B, Larsson $Y$. Administration of vitamin $K$. 10 newborn infants and childhood cancer. Brit Med J 1993;307:89-91.

160. Klebanoff MA, Read SR, Mills IL, Shiono PH. The risk of childhood cancer after neonatat exposure to vitamin K. N Eng I Med 1993;329:905-8.

161. Olson $\mathrm{JH}_{\text {. Hertz } \mathrm{H}}$, Blinkenberg $\mathrm{K}$, Verder $\mathrm{H}$. Vitamin $\mathrm{K}$ regimens and incidence of childhood cancer in Denmark. Brit Med J 1994;308:895-6.

162. Motohara K, Takagi S, Endo F. Kiyota Y. Matsuda I. Oral supplementation of vitamin K for pregnant women and effects on levels of plasma vitamin $K$ and PIVKA-II in the neonate. J Pediat Gastroen Nutr 1990;11:32-6.

163. Thom TJ. International mortality from heart disease: rates and trends. Int J Epidemiol $1989,18($ Suppl 1):S20-8.

164. Ross R. The pathogenesis of atherosclerosis: a perspective for the 1990s. Nature 1993:362:801-9.

165. Badimon JJ, Fuster V Chesebro JH, Badimon L. Coronary alherosclerosis. A multifactortial disease. Circulation 1993:87(Suppll1):11-3-11-16.

166. Wight TN. Cel biology of arterial proteoglycans. Arteriosclerosis $1989 ; 9: 1-20$.

167. Black AS, Kanat IO. A review of soft tissue calcifications. J Foot Surg 1985:24:243-50.

168. Kinn KM. Calcification of matrix vesicles in human aortic valve and aortic media. fred Proc $1976 ; 35: 156-62$.

169. Anderson HC. Matrix vesicle calcification. Fed Proc 1976:35:105-8.

170. Urry DW. On the molecular basis for vascular calcification. Perspect Biol Med 1974;68-84.

171. Virchow R. Cellular pahology: as based upon physiological and pathological histology. Dover, New York (unabridged reprinting) 1971:404-8.

172. Long ER. Development of our knowledge of arteriosclerosis. In: Blumenthal HT, editor. Cowdry's arteriosclerosis: a survey of the problems. Springfield, ILL: Charles C Thomas Publishing, 1967:6-7 
173. Bigi A, Foresti E, Ripamoni A. Roveri N. Structural and chemical characterization of the morganic deposits in calcified human aortic wall. Inorganic Chimica Acta 1980;55:81-5.

174. Schmid K, McSharry WO, Pameijer CH, Binette JP. Chemical and physicochemical studies on the mineral deposits of the human atheroscleronte aorta. Atherosclerosis 1980;37:199-210.

175. McCullagh KA, Ballian G. Collagen characterisation and cell transformation in buman atherosclerosis. Nature 1975:258:73-5.

176. Giachelli CM, Bad N, Almeida M, Denhardi DT. Alpers CE. Schwartz SM. Osteopontin is elevated during neointima formation in rat arteries and is a novel component of humam atherosclerotic plaques. J Clin Invest 1993;92:1686-96.

177. Badimon J., Fuster V, Chesebro JH, Badimon L. Coronary atherosclerosis. A multifactorial disease. Circulation 1993:87(SuppIII) II-3-11-16.

178. Boström K. Watson KE, Horn S, Wortham C. Herman IM. Demer LL. Bone morphogenetic protein expression in human atherosclerotic lesions. J Clin Invest 1993;91:1800-9.

179. Watson $K \mathbb{E}$. Boström $\mathbb{K}$, Ravindranath $R$, Lam $T$, Norton $\mathbb{B}$, Demer LL. TGF $\beta 1$ and 25 hydroxychölesterol stimulate osteoblast wike vascular cells to callify. J Clin Invest $1994: 93: 2106-13$.

180. Demer LL, Watson KE, Boström K. Mechanism of calcification in atherosclerosis. Trends Cardiovasc Med 1994:4:45-9.

181. Doherty TM. Detrano RC. Coronary arterial calcification as an actice process: a new perspeclive on an old problem. Calcif Tissue Int 1994:54:224-30.

182. Levy RI. Lian JB, Gallop PM. Atherocalcin a $\gamma$-carboxyglutamic acid containing protein from atherosclerotic plaque. Biochem Biophys Res Commun 1979;91:41-9.

183. Deyl $Z$, Macek $K$, Vancikova $O$, Adam M. The presence of $\gamma$-carboxyglutamic acid-containing protein in atheromatous aortae. Bioch Bioph Acta 1979;581:307-15.

184. Levy RJ, Gundberg $\mathrm{C}$, Scheinman R. The identification of the vitamin K-dependent bone protein osteocalcin as one of the $\gamma$-carboxyglutamic acid containing proteins present in calcified atherosclerotic plaque and mineralized heart valves. Atherosclerosis 1983:46:49-56.

185. Keeley FW, Sitarz EE. Characterization of proteins from the calcified matrix of atherosclerotic human aorta. Atherosclerosis $1983 ; 46: 29-40$.

186. Levy RJ. Howard SL, Oshry LJ. Carboxyglutamic acid (Gla) containing proteins of human calcified atherosclerotic plaque solubilized by EDTA. Atherosclerosis 1986;59:155-60.

187. Severson AR, Ingram RT, Schwartz RS. Fitzatrick LA. Immunohistochemical staining of porcine vascular smooth muscle cells grown in vitro for bone sialoprotein, osteocalcin, osteopontin, osteonectin and procollagen type 1. Anatomical Record Suppl 1993:1:103.

188. Shamahan CM, Cary NRB, Metcalfe JC. Weissberg PL. High expression of genes for calcification-regulating proteins in human atherosclerotic plaques. J Clin Invest 1994;93:2393-2402.

189. Loeser R, Carlson CS. Tulli H, Jerome WG, Miller L, Wallin R. Articular-cartilage matrix ycarboxyglutamic acid-containing protein. Characterization and immunolocalization. Biochem $J$ $1992: 282:-6$

190. Wan Hatrlem. LJM, Soute BAM, Hemker HC, Vermeer C. Characterization of Gla-containing proteins trom calcified human atherosclerotic plaques. In: Suttie JW, editor. Current Advances in Vitamin K Research. New York: Elsevier North Holland, 1988:287-92. 




\section{SERUM OSTEOCALCIN AS A MARKER FOR VITAMIN K'STATUS IN PREGNANT WOMEN AND THEIR NEWBORN BABIES}

Kon-Siong G. Jie', Karly Hamulyák², Birgit L.M.G. Gijsbers', Frans J.M.E. Roumen $^{3}$, and Cees Vermeer ${ }^{1}$

" Department of Biochemistry and Cardiovascular Research Institute (CARIM). University of Limburg, Maastricht

2 Department of Haenarology, University Hospital, Maasiricht

3 Department of Obstetrics, St. Elisabeth Clinic, Heerlen, The Netherlands

\section{SUMMARY}

Osteocalcin (bone Gla-protein) is a vitamin K-dependent protein synthesized by osteoblasts. Its hydroxyapatite binding capacity $(\mathrm{HBC})$ is generally used to estimate the Gla-content of circulating osteocalcin. Here we have used the HBC of serum osteocalcin as a marker for the vitamin $\mathrm{K}$ status in pregnant women and their offspring. For all cases investigated the HBC values in the cord samples were substantially lower than in the corresponding maternal ones. Babies from mothers who had been treated with vitamin $\mathrm{K}$ during the last 6 weeks prior to delivery, had significantly higher $\mathrm{HBC}$ values than those from a placebo group. The results presented in this paper are indicative for a generally occurring vitamin $\mathrm{K}$ deficiency in newborns. At delivery the HBC in untreated women was low as well. In both the placebo- and the vitamin K-group a good correlation was found between the $\mathrm{HBC}$ values in paired samples from mother and child. Whether the maternall $\mathrm{HBC}$ value may be used as a prenatal marker for estimating the fetal vitamin $\mathrm{K}$ status remains to be seen.

Published in: Thrombosis and Haemostasis 1992;68:388-91. 


\section{INTRODUCTION}

Vitamin $K$ is required for the synthesis of $\gamma$-carboxyglutamate (Gla) residues in a wide variety of proteins." Gla-containing proteins are found in blood plasma (e.g. some blood coagulation factors) as well as in bone tissue (osteocalcin and matrix Gla-protein). During periods of suboptimal vitamin $\mathrm{K}$ status the various Gla-proteins enter the bloodstream in an undercarboxylated form, which means that the number of Gla residues per molecule is below normal, and may even become zero. ${ }^{2}$ In this paper we will refer to the term vitamin $K$ deficiency in those cases in which at least one of the Gla-containing proteins is undercarboxylated due to an inadequate vitamin $\mathrm{K}$ status. ${ }^{3}$ It is well known that newborns may readily develop a bleeding tendency related to vitamin $\mathrm{K}$ deficiency. Risk factors are: maternal drug ingestion, ${ }^{4.5}$ low dietary intake of vitamin $\mathrm{K}$ (generally related to breast-feeding), ${ }^{6.7}$ as well as fat malabsorption. ${ }^{8}$ Sometimes, however, vitamin $\mathrm{K}$ deficiency is also seen unexpectedly, in previously healthy newborns. ${ }^{\text {A }}$ suboptimal vitamin $K$ status is associated with the so called hemorraghic disease of the newborn (HDN), a phenomenon with a low incidence ( 1 per 4000 babies), but with a high morbidity and mortality. ${ }^{10}$ To prevent HDN, the prophylactic administration of vitamin $\mathrm{K}$ to all newborns is propagated in most Western countries and Japan.

Without doubt the circulating levels of vitamin $\mathrm{K}$ in newborns are low," but evidence that plasma and tissue concentrations of vitamin $\mathrm{K}$ are correlated is conflicting. ${ }^{12.13}$ Moreover, the minimal dose of vitamin $\mathbb{K}$ required for full carboxylation of all Gla-proteins is also unknown. With the help of various blood coagulation tests it has been shown that in the newborn the level of the vitamin $\mathrm{K}$-dependent coagulation factors is low $(40-60 \%$ of the adult values), but data from experimental animals strongly suggest that this can be explained by a low level of transcription of mRNA. ${ }^{44.15}$ More solid evidence for vitamin $\mathrm{K}$ deficiency would have been supplied by the identification of non or partly carboxylated Gla-proteins, and until now almost all efforts have been focused on the detection of descarboxy-prothrombin..$^{16,17}$

It may be questionable whether coagulation factors are the best choice to establish a subject's vitamin $\mathrm{K}$ status: the liver is capable of extracting vitamin $\mathrm{K}$ preferentially and efficiently from the blood stream, ${ }^{12}$ so that given a marginal vitamin $K$ status the extrahepatic tissues will be the first ones to experience vitamin $\mathrm{K}$ deficiency. During recent years we have therefore successfully used the bone Gla-protein osteocalcin as a marker for vitamin $\mathrm{K}$ status. ${ }^{18}$ By measuring the immunoreactive osteocalcin (iroc) before and after adsorption to hydroxyapatite, its hydroxyapatite binding capacity (HBC) may be calculated, and this is 
generally regarded as a measure for the protein's Gla-content." In the study presented in this paper we have used the HBC of iroc in cord serum to assess the vitamin $\mathrm{K}$ status of newborns; in addition we have measured the effect on this marker of vitamin $\mathrm{K}$ administration to the mothers during the last six weeks of pregnancy.

\section{MATERIALS AND METHODS}

\section{Study design}

At the 34th week of their pregnancy healthy women were asked to participate in our study. To detect a difference in HBC of $15 \%$, it was calculated that at least 17 participants would be required per group (estimated SD: 12\%, two-tailed p value $<0.05$ with a power of $90 \% .{ }^{20}$ All women had passed an uneventful course of pregnancy and used no drugs known to interfere with haemostasis or vitamin $\mathrm{K}$ status. The participants were randomly assigned to receive an oral dose of either vitamin $K_{1}$ (Konakion $^{\mathbb{1}}, 1 \mathrm{mg} /$ day) or a placebo until delivery. Only women with a treatment period of at least 4 weeks were included in the study. With regard to their mean age and clinical characteristics there were no significant differences between both groups. Konakion was obtained in drop bottles (10 $\mathrm{mg} / \mathrm{ml}$ ) from Hoffmann-La Roche (Basle, Switzerland). At inclusion in the protocol venous blood samples were drawn from the mothers, at delivery samples were taken both from the mothers and from the umbilical vein, immediately after clamping of the cords. The study protocol was approved by the Medical Ethical Committee of the University Hospital, and a written informed consent was obtained from each participant. In all cases the course of the pregnancy remained uneventful, and the babies were born at term by normal vaginal delivery with Apgar scores $>8$ at $1 \mathrm{~min}$. According to this protocol 24 women and their babies could be evaluated in the vitamin K-treated group, and 20 in the placebo group.

\section{Blood handling}

Blood was taken by venipuncture and used for the preparation of citrated plasma and serum. Plasma was prepared by collecting the blood in $10 \%(\mathrm{v} / \mathrm{v})$ of $0.1 \mathrm{M}$ trisodium citrate, followed by centrifugation for $15 \mathrm{~min}$ at $2000 \mathrm{x} \mathrm{g}$. Serum was prepared by incubating the blood in plastic tubes at room temperature for $2 \mathrm{~h}$, and centrifugation for $15 \mathrm{~min}$ at $2000 \mathrm{x}$ g. All samples were immediately subdivided into $0.5 \mathrm{ml}$ aliquots and frozen at $-80^{\circ} \mathrm{C}$ until further use. 


\section{Coagulation assays}

Prothrombin concentrations were assessed with a one-stage assay, and the sum of prothrombin + descarboxy-prothrombin with a two-stage assay after activation with Echis carinatus venom. ${ }^{21}$ If only prothrombin is present in the sample, the ratio between these two tests should be around 1 (normal range: 0.9-1.1), if the ratio is $<0.9$ this is generally regarded as a strong indication for the occurrence of descarboxy-prothrombin; with this method the detection limit for descarboxyprothrombin is about $5 \mu \mathrm{g} / \mathrm{ml} .^{22}$

\section{Osteocalcin}

Serum irOC concentrations were assessed with the radioimmunoassay kit from Incstar (Stillwater, MN, 111), and the HBC was determined after adsorption of 0.5 $\mathrm{ml}$ of serum with $50 \mathrm{mg}$ of hydroxyapatite (BDH, Poole, UK). The HBC of serum osteocalcin is expressed as the percentage bound after adsorption to hydroxyapatite (normal adult range: $70-80 \%$ ). 18

\section{Vitamin $K_{P}$}

Serum vitamin $\mathrm{K}_{1}$-levels were determined by high performance liquid chromatography, followed by electrochemical detection as described by Hart et al ${ }^{2,3}$

\section{Statistical analysis}

Changes within and between treatment groups were analyzed with the two-sided paired and unpaired Student's t-test, respectively. Linear regression analysis was performed to investigate the relationship between two variables. Analyses were performed using the software package SPSS/PC+ version 3.1 (SPSS Inc., Chicago, III). All data presented are expressed as the means \pm S.E.

\section{RESULTS}

\section{Maternal samples}

Pregnant women entered our study six weeks before the estimated day of delivery, and were randomized into two groups: one receiving vitamin $K_{1}$ and the other a placebo. In the maternal plasma samples the one- and two-stage prothrombin concentrations were within the normal range in both study groups, and descarboxy-prothrombin could neither be detected at the start of the study nor at delivery (data not shown). In the sera the following parameters were tested: irOC, the $\mathrm{HBC}$ of serum iroc, and the vitamin $\mathrm{K}_{1}$-concentration. At the start of the experiment there was no statistical difference between these markers in both 
Table 1: Effect of witamin $K$ treatment in pregmant wonen and their bobiss

\begin{tabular}{|c|c|c|c|}
\hline Sannple origin & $\begin{array}{l}\mathrm{irOC} \\
(\mathrm{ng} / \mathrm{ml})\end{array}$ & $\begin{array}{l}\text { HBC } \\
\text { (\% adsorbed) }\end{array}$ & $\begin{array}{l}\text { witurin } K \\
\text { (pgrml) }\end{array}$ \\
\hline $\begin{array}{l}\text { a. Normal adult range } \\
\text { maternal starting valu }\end{array}$ & $2-7$ & $70-80$ & $100-1000$ \\
\hline b. Vitamin $\mathrm{K}$ group & $2.33 \pm 0.31$ & $73.1 \pm 1.7$ & n.d. \\
\hline $\begin{array}{l}\text { c. Placebo group } \\
\text { difference b/c }\end{array}$ & $\begin{array}{l}1.87 \pm 0.17 \\
\text { N.S. }\end{array}$ & $\begin{array}{l}70.5 \pm 3.7 \\
\text { N.S. }\end{array}$ & n.d. \\
\hline \multicolumn{4}{|c|}{ matermal values at delivery } \\
\hline d. Vitamin K group & $2.38 \pm 0.26$ & $76.6 \pm 1.9$ & $2512 \pm 758$ \\
\hline e. Placebo group & $2.04 \pm 0.25$ & $65.5 \pm 3.7$ & $328 \pm \| 11$ \\
\hline $\begin{array}{l}\text { difference d/e } \\
\text { in cord serum }\end{array}$ & \multicolumn{3}{|c|}{ in cord serum } \\
\hline f. Vitamin $K$ group & $6.31 \pm 0.49$ & $53.2 \pm 2.2$ & $43.2 \pm 2.2$ \\
\hline g. Placebo group & $6.61 \pm 0.57$ & $35.6 \pm 2.7$ & $<20$ \\
\hline difference $\mathrm{f} / \mathrm{g}$ & N.S. & $p<0.0001$ & $p<0.0 \mathbb{1}$ \\
\hline
\end{tabular}

The normal adult ranges for the various markers are from refs. 8, 9, 17, 22 and 23 . N.S. stands for not significant, n.d. for nor determined. Further details are given in the text.

groups (Table 1, lines b and c). At delivery the mean HBC value in the vitamin $\mathrm{K}$ group was significantly higher $(\mathrm{p}<0.02$ ) than the placebo group (Table 1. lines $d$ and $e$ ). In the latter group 11 out of 20 samples were bellow the normal adult range. As was to be expected, the circulating vitamin $\mathbb{K}$ levels in the vitamin $\mathrm{K}$-treated group were high and reached about two- to three-fold times the upper normal adult level. In the placebo group the circulating vitamin $K_{4}$-levels were low but within the normal adult range for all participants.

\section{Cord samples}

As in the maternal plasma samples, no descarboxy-prothrombin could be detected in the cord plasmas with the classical coagulation tests (data not shown). In cord serum (Table 1, lines $f$ and $g$ ) the iroc levels were higher than those of the mothers, which is consistent with the high osteoblast activity in the rapidly growing fetal bones. No correlation was found between the irOC levels in maternal 


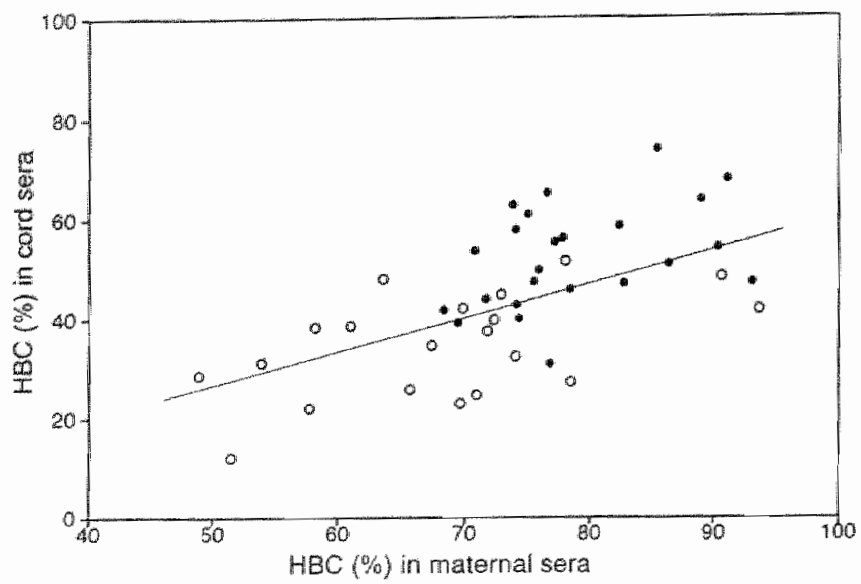

Figure 1. Correlation berween the HBC values in mohers and their newborn babies. The data presented are from the witamin $K$-rreated ( ) and from the placebo fol group. The straight line was fined with a computer progran equipped for linear regression calculations, with $r=+0.59$ and $p<0.0003$.

and cord blood samples, which is in accordance with earlier reported data. ${ }^{24}$ In all cord serum samples the HBC values were lower than in the maternal ones, with extremely low values for the cord sera from the placebo group. Significantly higher HBC values $(\mathrm{p}<0.0001)$ were found in the cord samples from the vitamin K-treated group, but in only one of the 24 cases did it reach the normal aduit range. In the placebo- as well as the vitamin $\mathrm{K}$-treated group the $\mathrm{HBC}$ of the newborns appeared to be significantly correlated with the maternal values (Figure $1, r=0.59, \mathrm{p}<0.0003$ ). In all cord samples from the placebo group the vitamin $\mathrm{K}$ concentrations remained below the detection limit $(20 \mathrm{pg} / \mathrm{ml})$, whereas in the vitamin $K_{1}$ group they were not more than about $40 \mathrm{pg} / \mathrm{ml}$ (see Table 1, last column). The latter value is well below the normal range, and over 60 fold lower than the corresponding maternal values. 


\section{DISCUSSION}

Whether a general vitamin K-deficiency is common in all healthy newborn babies is a matter of debate. By definition, a marker for vitamin $\mathrm{K}$-deficiency would be the occurrence of undercarboxylated vitamin K-dependent proteins. Additional confirmation that the defect is not due to an impaired carboxylation enzyme system, should then be obtained by correction of the amount of undercarboxylated proteins after vitamin $\mathrm{K}$-administration. Using the classical coagulation tests we have not been able to detect descarboxy-prothrombin in either maternal or cord plasma samples. This is consistent with the results of other studies in which incompletely carboxylated prothrombin has only rarely been found and if so, usually in trace amounts. ${ }^{25}$ With more sensitive tests others have demonstrated the presence of minute amounts of descarboxy-prothrombin in $21-89 \%$ of the newborns investigated, ${ }^{16.17}$ but these low levels may probably be regarded as physiological rather than as pathological. This view is supported further by the observation that trace amounts of descarboxy-prothrombin could also be detected in most healthy adult plasma samples. ${ }^{26}$

Here we report that in a group of 20 untreated newborns the HBC values were extremely low in all cases, reaching values comparable with those generally found in patients on oral anticoagulant therapy. ${ }^{27}$ In 11 of the 20 corresponding maternal samples we found $\mathrm{HBC}$ values below the normal adult range, suggesting that at least some of these women were subclinically vitamin $K$ deficient. This is consistent with the observation of Blanchard et al.,17 who found descarboxyprothrombin in $71 \%$ of the mothers at delivery. In a second group $(\mathrm{n}=24)$ the mothers were treated daily with $1 \mathrm{mg}$ of vitamin $\mathrm{K}$ during the last 6 weeks of pregnancy. With this treatment the $\mathrm{HBC}$ in cord serum increased significantly, but in only one out of the 24 cases did it reach the normal adult range. Several mechanisms may underlie the poor response of fetal osteocalcin to maternal vitamin $\mathrm{K}$-ingestion: a) the fetal vitamin $\mathrm{K}$ status is sufficient, but its carboxylase system is still immature and unable to maintain the production of fully carboxylated osteocalcin; b) the dosage of vitamin $\mathrm{K}_{1}$ which was applied in this study is too low to ensure full carboxylation of irOC of the babies in utero; $c$ ) even after six weeks of maternal vitamin $\mathrm{K}_{1}$-intake the placental transport of the vitamin is insufficient to ensure full carboxylation of the extrahepatic Gla-proteins. The frequently postulated increased requirements for vitamin $\mathrm{K}$ during fetal and neonatal development (e.g. because of the osteoblast activity) may contribute to the latter possibility.

We have tried to discriminate between these possibilities by the direct analysis of the vitamin $K_{1}$-concentration in the maternal sera and in the corresponding 
cord samples. In the placebo-treated group the vitamin $\mathrm{K}_{4}$-levels were undetectable. Even in the $K_{1}$-treated group the vitamin concentration in cord serum was extremely low (i.e. 2.5-fold below the lower normal adult level and 60 -fold below the corresponding maternal values), despite the high vitamin $K_{1}$ levels in the maternal sera. This demonstrates once more the substantial placental barrier for vitamin $\mathrm{K}$, which was also reported by other authors, ${ }^{28.29}$ and suggests that the low HBC values found in newborns most probably result from their suboptimal vitamin $\mathrm{K}$-status. The very low $\mathrm{HBC}$ values found in all cord sera of the placebo group indicate that the occurrence of substantial amounts of descarboxy-osteocalcin is common in newborns. Because at best trace amounts of descarboxy-prothrombin are detectable in only a fraction of all cord plasmas, ${ }^{16,17}$ we conclude that descarboxy-osteocalcin is a more sensitive marker for vitamin $\mathrm{K}$ deficiency of the newborn than is descarboxy-prothrombin.

The significant correlation between the HBC of the mothers and their babies in the vitamin $K_{1}$ - as well as the placebo-group (Figure 1) indicates that in general the vitamin $\mathrm{K}$-status of the babies improved with a better vitamin $\mathrm{K}$-status of the mothers, and that their osteoblastic vitamin $\mathbb{K}$-dependent carboxylase system had sufficiently developed to react appropriately. At this time we have no reason to suppose that a different situation would exist in the liver. Therefore the coupling between the maternal and neonatal HBC values may open up the possibility to use the maternal $\mathrm{HBC}$ during the last weeks of pregnancy as a marker for the vitamin K-status of the fetus. This may be of particular importance for pregnant women known to be at risk for developing vitamin K-deficiency, such as those using anticonvulsant and tuberculostatic drugs or certain an tibiotics. ${ }^{4,30,31}$ Vitamin $\mathrm{K}$-administration to these women is not uncommon, but the doses required to prevent perinatal haemorrhages are unknown. By using the maternal $\mathrm{HBC}$ as a marker, the dose/effect relation of vitamin K-administration could be measured, so that the maternal HBC could be maintained in the normal adult range. In this way, as suggested by the data in this paper, the fetal vitamin $\mathrm{K}$-status will be improved. Further research will have to demonstrate whether this is accompanied by a decrease in the risk for HDN.

\section{ACKNOWLEDGMENTS}

The authors wish to thank drs. M.J. Shearer (Department of Haematology, Guy"s Hospital, London) and H.H.W. Thijssen (Department of Pharmacology, University of Limburg, Maastricht) for their help in determining serum vitamin $\mathbf{K}_{1}$ levels. 


\section{REFERENCES}

1. Vermeer C. Gammacarboxygluamate-containing proteins and the vitamin K-dependen carboxy lase. Biochem J 1990;266:625-6.

2. Friedman PA. Vitamin K-dependent proteins. N Engl J Med $1984 ; 310: 1458-60$.

3. Vermeer $\mathrm{C}$, Hamulyak $\mathrm{K}$. Pathophysiology of vitamin $\mathrm{K}$-deficiency and aral anticoagulants. Thromb Haemostas 1991:66:153-9.

4. Bleyer WA. Skinner AL. Fatal neonatal haemorrhage after maternal anticonvulsant therapy. JAMA $1976 ; 235: 626-7$.

5. Stevenson RE, Burton M, Fenlanto GJ. Hazards of oral anticaagulants during pregnancy. JAMA $1980 ; 243: 1549-51$

6. O'Connor ME, Livingstone DS, Hannah J, Wilkins D. Vitamin $\mathrm{K}$ deficiency and breast-feeding. Am I Dis Child 1983;137:601-2.

7. Haroon $Y$, Shearer MJ, Rahim S, Gunn WC, McEnery G, Barkhan P. The content of phylloquinone (vitamin $K_{1}$ ) in human milk, cow"s milk and infant formula foods determined by high-performance liquid chromatography. I Nutr 1982;112:1105-17.

8. Nagao T, Nakayama $K$. Vitamin $K$ deficiency in Japan. Pediatrics 1984:74:315-6.

9. von Kries R, Shearer MJ, Göbel U, Vitamin K in infancy, Eur J Pediatr 1988;147: 106-12.

10. Shearer MJ. Vitamin $K$ and vitamin K-dependent proteins. Brit J Haemallol 1990:75:156-62.

11. Shearer MJ, Rahim S, Barkhan $P$, Stimmler L. Plasma vitamin $K_{v}$ in mothers and their newborn babies. Lancet 1982;11:460-3.

12. Kindberg $C G$, Suntie JW. Effect of various intakes of phylloquinone on signs of vatamin $K$ deficjency and serum and liver phylloquinone concentrations in the rat. J Nutr 1989:119:175-80.

13. Usui $Y$, Tanimura $H$, Nishimura $N$, Kobayashi $\mathbb{N}$ Okanoue $T$, Ozawa K. Vitamin K concentrations in the plasma and liver of surgical patients. Am J Clin Nutr 1990;51:846 52.

14. Yao S-N, DeSilva AH, Kurachi S, Samuelson LC, Kurachi K. Characterization of a mouse factor IX CDNA and developmental regulation of the factor IX gene expression in liver. Thromb Hatmostas 1991:65:52-8.

15. Jamison CS. Degen SJF. Prenatal and postnatal expression of mRNA coding for rat prothrombin. Biochim Biophys Acta 1991:1088:208-16.

16. Motohara K. Endo F, Masuda 1. Effect of wiamin K administration on acarboxy prothrombin (PIVKA-LI) levels in newborns, Lancet 1985;11:242-4.

17. Blanchand RA. Furie BC, Bamen J, Peck C. Faye K, Jacobs M, Defurio L, Furie B. Vitamin K deficiency in newborns and their mothers. Thromb Haemostas 1985:54:1340.

18. Knapen MHJ. Hamulyák K, Vermeer $C$. The effect of vitamin $K$ supplementation on circulang osteocalcin (bone Gla-protein) and urinary calcium excretion. Am lm Med 1989:1 1.1:1001-5.

19. Price PA. Role of vitamin K-dependent proteins in bone metabolism. Armu Rev Nutr $1988 ; 8: 565-83$.

20. Levine MN, Hirsh J. Sample size in the planning and interpretation of clinical trials. Thromb Haemostas 1987;58:953-6.

21. Vermeer C. Soute BAM Hemker HC. A new method for the preparation of artificial factor II reagents from normal human and bovine plasma. Thromb Res 1977:10:495-507.

22. Suttie JW, Kindberg $C G$, Greger $J$ L. Bang NU. Effects of vitamin $K$ (phylloquinone) restriction in the human. In: Suttie IW, editor. Current advances in vitamin $K$ research. New York, Elsevier. $1988: 465-76$.

23. Hart JP. Shearer MJ. McCarthy PT. Enhanced sensitivity for the determination of endogenous phylloquinone (vitamin $\mathrm{K}_{\mathrm{f}}$ ) in plasma using high-performance liquid chromatography with dual electrode electro chemical detection. Analyst $1985 ; 110: 1181-4$. 
24. Cole DEC, Carpenter TO, Gundberg CM. Serum osteocalcin concentrations in children with metabolic bone discase. I Pediatr 1985;106:770-6.

25. Pietersma-de Bruyn ALJM. Vitamin $K$ in the newborn. Thesis, Leiden 1990.

26. Soulier JP, Gozin $D$. Lefrere JJ. A new method to assay desgammacarboxyprothrombin. Results obtained in 75 cases of hepatocellular carcinoma. Gastroenterology 1986;91:1258-62.

27. van Haarlem LJM, Knapen MHJ. Hamulyák $K$, Vermeer $C$. Circulating osteocalcin during oral an ticoagulant therapy. Thromb Haemostas 1988;60;79-82.

28. Hamulyák $K$, de Boer-wan den Berg MAG, Thijssen HHW, Hemker HC, Vermeer $C$. The placental transport of $\left[{ }^{3} \mathrm{H}\right]$ vitamin $\mathrm{K}_{\mathrm{f}}$ in rats. Brit $\mathrm{J}$ Haematol $1987 ; 65: 335 \mathrm{~m}$.

29. Mandelbrot L, Guillaumont $M$, Leclercq M, Lefrère JJ, Gozin D, Daffos F, Forestier F. Placental transfer of vitamin $K_{1}$ and its implications in fetal haemostasis. Thromb Haemostas 1988;60:39-43.

30. Deblay $\mathrm{MF}^{\mathrm{F}}$, Vert $\mathrm{P}$, Andre $\mathrm{M}$, Marchal F. Transplacental vitamin $K$ prevents haemorrhagic disease of infiant of epileptic mother. Lancet 1982;1:1247.

31. Lane PA. Hathaway WE. Vitamin K in infancy. J Pediatr 1985:3:351-9. 




\title{
CHAPTER
}

\section{EFFECTS OF VITAMIN K AND ORAL ANTICOAGULANTS ON URINARY CALCIUM EXCRETION}

\author{
Kon-Siong G. Jie,' Birgit L.M.G. Gijsbers,' Marjo H.J. Knapen,' Karly \\ Hamulyák ${ }^{2}$, Herman $\mathbb{L}$. Frank ${ }^{3}$ and Cees Vermeer.! \\ 1 Deparment of Biochemistry, Cardiovascular Research Institute (CARIM), Universiry of Limburg. \\ Maastricht \\ 2 Department of Haematology, University Hospital Maastricht \\ 3 Department of Cardiology, University Hospital Masstricht, The Nether ands.
}

\section{SUMMARY}

In a subgroup of postmenopausal women vitamin $K$ induced a decrease of the urinary calcium loss. This effect was significant $(\mathrm{p}<0.0001)$ in the so-called fast losers of calcium (calcium/creatinine ratio $>0.5$ ). To find out whether vitamin $\mathrm{K}$ antagonists would have an opposite effect, a study was started among 141 persons on long-term oral anticoagulant therapy. In this population the number of fast losers was recorded, and compared to that in a group of age- and sexmatched non-treated controls. Notably in young men the fraction of fast losers was significantly higher in the anticoagulant-treated group than in the control group ( 25 vs $0 \%, \mathrm{p}<0.02$ ). Differences between treated and non-treated groups may also be found in other markers for calcium and bone metabolism, notably in serum osteocalcin concentration and in urinary hydroxyproline excretion. The conclusion of our study is that oral anticoagulant treatment must be regarded as a potential risk factor for a high loss of urinary calcium.

Published in: Britisch Journal of Haematology 1993;83:100-4. 


\section{INTRODUCTION}

It is well known that vitamin $\mathrm{K}$ functions as a cofactor in the posttranslational conversion of glutamate residues into gamma-carboxyglutamate or Gla. ${ }^{1,2,3}$ The only known function of these Gla-residues is that they form $\mathrm{Ca}^{2+}$-binding groups in the proteins to which they belong. Hence all Gla-containing proteins are $\mathrm{Ca}^{2+-}$ binding ones. Well known examples of Gla-proteins are those involved in blood coagulation. ${ }^{4}$ The most abundant Gla-protein in man, however, is the bone protein osteocalcin. ${ }^{5.6}$ Other Gla-proteins occurring in mineralized tissues are matrix Gla-protein, ${ }^{7}$ plaque Gla-protein ${ }^{8}$ and proteins found in renal stones ${ }^{9}$ and in ectopic calcifications of the skin. ${ }^{10}$ Although the precise function of these mineral-bound Gla-proteins is not clear at this time, it has frequently been suggested, that they may play a role in calcium metabolism.

Recently, we have stuclied a group of postmenopausal women who were recruited from the religious inhabitants of the convents near Maastricht. It was found that the Gla-content of their circulating immunoreactive osteocalcin was much lower than that in premenopausal subjects. "Upon vitamin $\mathrm{K}$ administration the osteocalcin Gla-content in the premenopausal women remained unaltered, but in the postmenopausal ones a clear and significant increase was observed. In parallel, it was found that vitamin $\mathrm{K}$ induced a substantial decrease of urinary calcium excretion, notably in those women who may be characterized as fast losers of calcium.

Obviously the inhabitants of a convent may not be representative of the population in general. Moreover the number of participants was too low to accurately define the groups of responders and non-responders to vitamin $\mathrm{K}$ treatment. Therefore we have started a number of trials among randomly selected civilians. The results of these investigations are presented in this paper and demonstrate that both vitamin $\mathrm{K}$ as well as vitamin $\mathrm{K}$ antagonists may affect the urinary calcium excretion.

\section{MATERIALS AND METHODS}

\section{Chemicals and drugs}

Vitamin $K_{1}$ (Konakion ${ }^{\oplus}$ ) was obtained in drop-bottles $(10 \mathrm{mg} / \mathrm{ml}$ ) from Hoffmann-La Roche (Basle, Switzerland). Patients were anticoagulated with acenocoumarol (Sintrom ${ }^{\text {}}$ ) from Ciba-Geigy (Basle, Switzerland). All chemicals used for laboratory techniques were of analytical grade or better. 


\section{Laboratory techniques}

Urinary calcium levels were established with an atomic absorption spectrophotometer (Perkin-Elmer, Norwalk, Conn.); creatinine and serum alkaline phosphatase were assayed with commercial kits from Hoffmann-La Roche using a Cobas centrifugal analyzer. Hydroxyproline (OHPro) concentrations were assessed with the Hypronosticon kit (Organon, Oss, The Netherlands). All concentrations were calculated in millimolar values. The urinary calcium and OHPro values are expressed as the calcium/creatinine ratio $(\mathrm{Ca} / \mathrm{creat})$ and the OHPro/creatinine ratio (OHPro/creat) throughout this paper. Immunoreactive serum osteocalcin concentrations (irOC) were assessed by radioimmunoassay (Incstar, Stillwater, Minn, IIl) and the hydroxyapatite binding capacity (HBC) of serum osteocalcin was measured as described earlier. "The intra- and inter-assay variations in the osteocalcin measurements were less than $10 \%$ and $5 \%$ respectivelly.

\section{Patients}

Oral anticoagulant-treated patients were selected from the thrombosis services in Heerlen and Maastricht after obtaining a written informed consent. Subjects were included when they had been on long-term ( $>12$ months) and stable oral anticoagulant treatment, with INR values within the desired range during more than $75 \%$ of the treatment period. Exclusion criteria were: recent bone fractures or bone pathology, hepatic or renal dysfunction, and the use of drugs known to affect the calcium and/or bone metabolism.

\section{Other participants}

Apparently healthy subjects were selected during the same period from the inhabitants of Maastricht by means of a call in the local newspaper. The same exclusion criteria as mentioned above were used for these participants.

\section{Urine collection and blood sampling}

To exclude dietary influences, urine was collected during the last $2 \mathrm{~h}$ of an overnight $\left(16 \mathrm{~h}\right.$ ) fasting period. ${ }^{12}$ The urine was brought to $\mathrm{pH} 1$ by adding a small amount of $6 \mathrm{~N} \mathrm{HCl}$, and frozen immediately until use. After the sample collection had been completed, all samples were tested in a serial way within one week. Fasting blood samples were obtained between 8.00 and $10.00 \mathrm{~h}$ in the morning. 


\section{Situdy design}

In the first trial the effect of vitamin $K$ on urinary calcium excretion was investigated in 125 postmenopausal women who were randomly assigned to oral treatment with either vitamin $\mathrm{K}(1 \mathrm{mg} / \mathrm{day}, \mathrm{n}=85)$ or placebo $(\mathrm{n}=40)$ for 1 month. In a second study, 143 subjects on long-term and stable oral anticoagulant treatment were compared with an age- and sex-matched control group. The participants selected for this trial were subdivided into four groups, each containing 25-57 patients. The age of the participants was either between 25 and 45 years or between 60 and 80 , and in both categories men and women were studied separately. In all participants the following markers for calcium metabolism were measured: serum irOC, $\mathrm{HBC}$ and alkaline phosphatase, and the urinary $\mathrm{Ca} / \mathrm{creat}$ and OHPro/creat ratios. All protocols were approved by the local ethics committee.

\section{Statistical analysis}

The software package SPSS/PC ${ }^{+}$version 3.1. (SPSS Inc., Chicago, III) was used for the statistical analysis and the 0.05 level of significance was chosen. Differences in proportions of subgroups were analyzed using the chi-square test. The continuity correction according to Yates was applied when appropriate. ${ }^{13}$ The data of the vitamin K treatment were analyzed by the two-sided paired Student"s $t$-test. Highly skewed data were analyzed with the Main-Whitney $U$ test and all data are expressed as the mean $\pm \mathrm{SE}$.

\section{RESULTS}

Effect of vitamin $K$ on urinary calcium excretion, definition of subgroups In an earlier study among a selected group of women we found a significant effect of vitamin $\mathrm{K}$ on urinary calcium excretion. "To test the universality of this observation, and to define more precisely the subgroup(s) in which the effect of vitamin $\mathrm{K}$ is to be expected, healthy postmenopausal women were randomly assigned to either vitamin $\mathrm{K}$ or placebo treatment for one month. In the vitamin K-lreated group as well as the placebo-treated one, the mean urinary Ca/creat ratio were similar, with starting values of $0.35( \pm 0.04)$ and $0.35( \pm 0.04)$, respectively. Also, the mean values within the groups had remained unchanged after one month of treatment with either vitamin $\mathrm{K}$ or placebo: $0.33( \pm 0.03)$ and 0.34 ( \pm 0.04 ), respectively. Inspection of the data revealed, however, that some subgroups of individuals responded with a clear decrease in their urinary calcium excretion. According to their initial $\mathrm{Ca} / \mathrm{creat}$ ratio, participants were therefore 


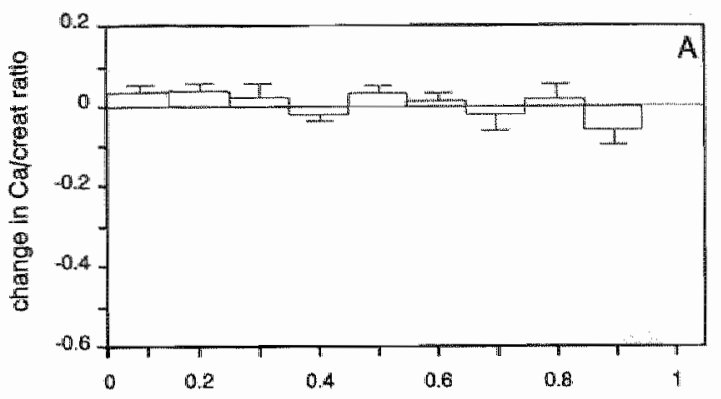

Figure 1. Whamin K-imaldat chamges in the wrinary calchm excretion. Participants were rreated for one monm with einher placebo $(A)$ or whom $K$ (B). The obsenved charge in the urinary calciand creathone natio is plotied agamst the ingthat values.

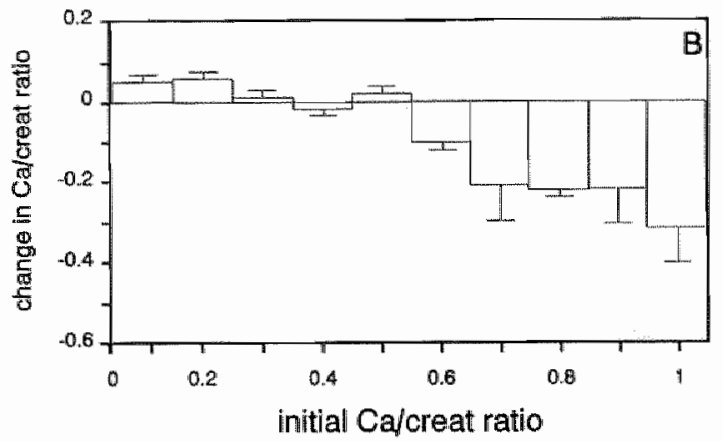

divided into subgroups the values of which increased with intervals of 0.1 . The data for the vitamin $\mathrm{K}$ - treated group (Figure $1 \mathrm{~B}$ ) show that a significant decrease in the urinary calcium excretion is only found in groups with a mean starting $\mathrm{Ca} / \mathrm{creat}$ ratio higher than 0.5 (mean decrease: -0.20 ; paired $t$-test: $\mathrm{p}<0.000 \mathrm{I}$ ). A similar effect was absent in the placebo group (Figure 1A). Participants with a very low initial $\mathrm{Ca} / \mathrm{creat}$ ratio (the intervals $0-0.1$ and $0.1-0.2$ ), on the other hand, showed a slight but significant vitamin $\mathbb{K}$-induced increase of their urinary calcium loss (mean increase: +0.06 ; paired $t$-test: $\mathrm{p}<0.0001$ ). No significant effect was found on the mean calcium loss in participants with a $\mathrm{Ca} /$ creat ratio in the 3 intervals between 0.2 and 0.5 . On the basis of these results the participants could thus be classified into three groups: positive responders, non-respon ders, and negative responders to vitamin $\mathrm{K}$ treatment, and it is at least striking that the limits found for these three categories almost precisely coincide with those generally used to define slow, normal and fast losers of urinary calcium. ${ }^{12}$ In the rest of this paper we will use a $\mathrm{Ca} / \mathrm{creat}$ ratio of 0.5 as the lower limit for fast losers of urinary callcium. 


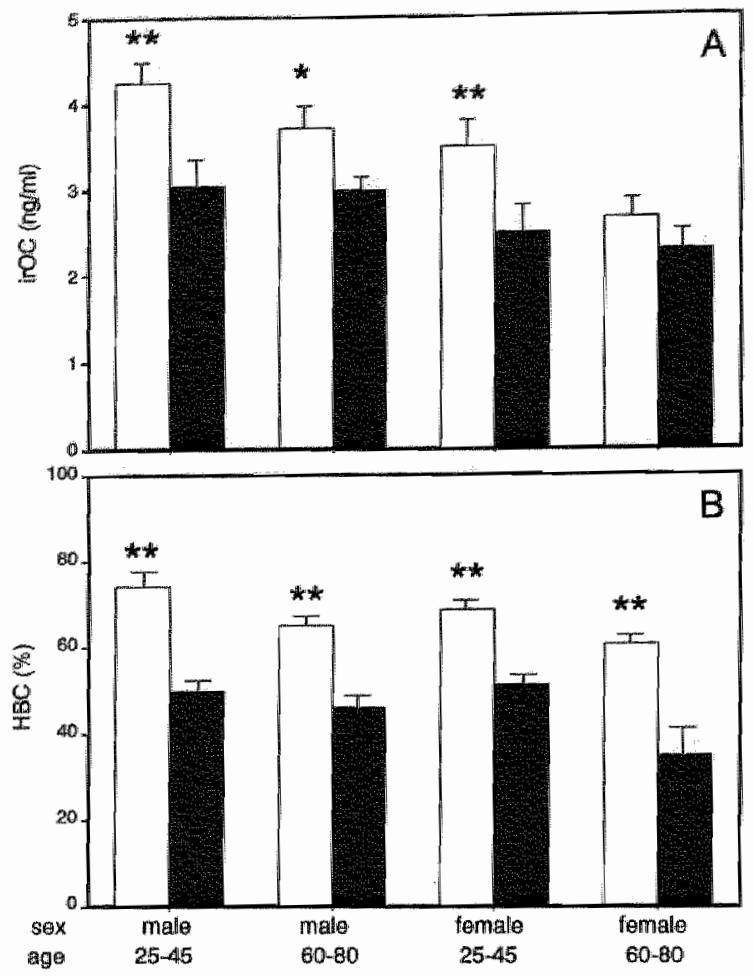

Figure 2. Effect of aral anncoagutants on serwan osteocalcin (irOC). Details of the experimental set-up are given in the Materials and Methods section. The closed bars represent the subjects on long-rerm, stable anticoagulant therapy, the open bars are the controls. All data are expressed as the mean I SE. Al: serum concentrations of immunoreactive osteocalcin (iroc). B: Mydroxyapatite binding capacity (HBC) of the irOC. *: $p<0.03$; * $p<0.02$.

\section{Effect of coumarin derivatives on markers for calcium metabolism}

The observed vitamin $\mathrm{K}$-induced changes in calcium metabolism justify the question of whether vitamin $\mathrm{K}$ antagonists (i.e. coumarin derivatives used for oral anticoagulant therapy), may have an opposite effect. This was investigated in a cohort study in which subjects on long-term and stable oral anticoagulant treatment were compared with an age- and sex-matched control group. In all patient groups the circulating irOC was significantly lower than in the corresponding controls, with a notable exception of the postmenopausal women in whom the serum irOC was low both in treated and untreated subjects (Figure $2 \mathrm{~A}$ ). In all anticoagulant-treated groups the $\mathrm{HBC}$ of the circulating osteocalcin was significantly lower than in the controls (Figure 2B). In Figure 3 we have plotted the percentage of fast losers in the various groups. It turned out that in all anticoagulated groups except that of the elderly women, the fraction of fast losers was higher than in the respective control groups. In the control groups of the young and elderly men we even observed no fast losers at all. The elevated number of fast losers reached the level of statistical significance only in the group of the young men (chi-square test: $p<0.02$ ). No significant differences were found 


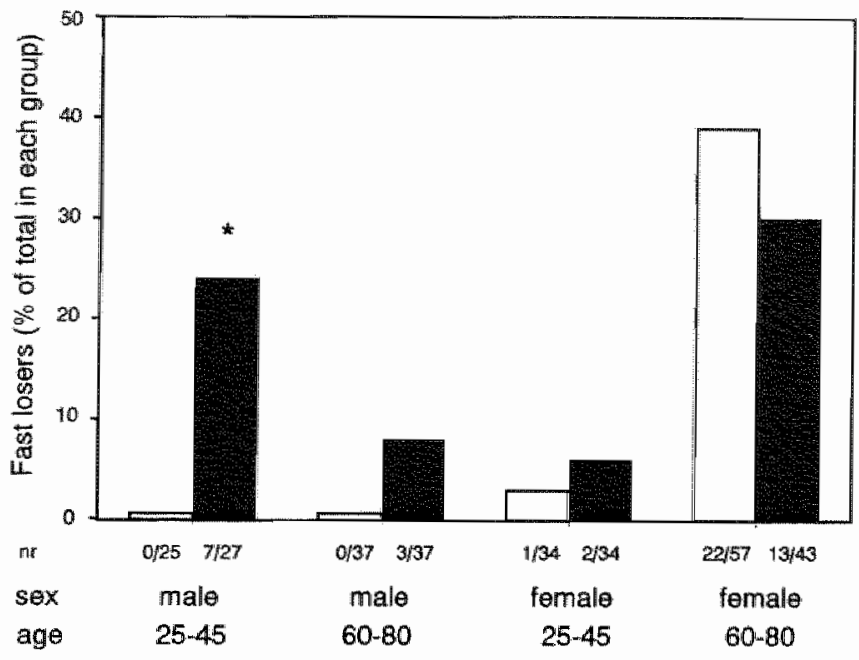

Figne 3. Effect of ont anricogulanrs on whangy calcum ercretion. The namber (nr) of fast losers in each group is ex pressed as a percentage of the rotal number of participants in that group. Differences between the anticongulated (closed bars) and control (open barsl groups were computed with the chi-square test. * $p<0.02$

between the mean serum alkaline phosphatase in the patient and the corresponding control groups (data not shown). On the other hand, a good correlation was observed between the urinary hy droxyproline and calcium excretion in the group of anticoagulated young men $(\mathrm{r}=0.52, \mathrm{p}<0.004$, see Figure 4$)$, as well as in both groups of postmenopausal women $(r=0.31, p<0.0005$ for both groups).

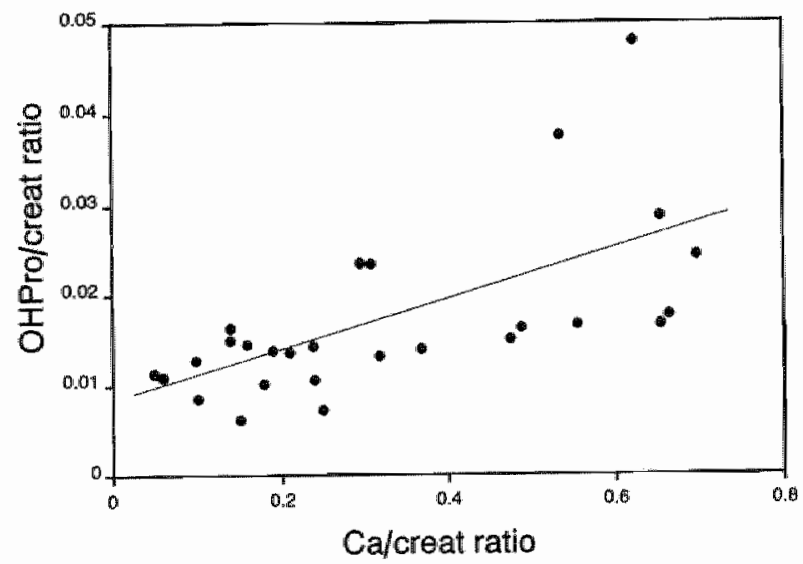

Figure 4. Correkation be tween the wrinary oHpro and calcium excretion in anticoagu. lated young men. The straight line was fitred with a computer progran equipped for linear regression calculations. Boih varia. bles were related according to the equation $y=0.009+0.022 x$. with $r=0.52$ and $p$ $<0,004$. 


\section{DISCUSSION}

The first link between vitamin $\mathrm{K}$-status and bone metabolism was made by Pettifor \& Benson in 1975, ${ }^{14}$ who found that oral anticoagulants, administered during the first trimester of pregnancy, induced severe bone malformations in 30 $\%$ of the fetuses. The discovery of the vitamin $\mathrm{K}$-dependent proteins osteocalcin (or bone Gla-protein) and matrix Gla-protein in bone tissue ${ }^{5.6 .7}$ further contributed to speculations about a putative role of vitamin $\mathrm{K}$-dependent proteins in the regulation of calcium phosphate deposition in bone tissue. Although both clinical and experimental data suggest a specific role for Gla-proteins in the mineralization of rapidly growing bone tissue, the precise function of each of these proteins remained unclear until now. On several occasions it has been proposed that, besides their effect on developing bone tissue, the bone Gla-proteins may be important for the maintenance of adult bone as well, but experiments with rats on long-term oral anticoagulant treatment did not prove this hypothesis satisfactorily. ${ }^{15}$ Moreover it remains questionable whether the results obtained with experimental animals may be extrapolated to man.

In a previous paper" we have demonstrated that vitamin $\mathrm{K}$ administration to post menopausal women may reduce the urinary calcium excretion, notably among the fast losers of calcium. Here we describe a second trial, in which we have substantially increased the number of participants, so that we could define more accurately the $\mathrm{Ca} / \mathrm{creat}$ ratio above which an effect of vitamin $\mathrm{K}$ could be seen. It turned out that a vitamin $\mathrm{K}$-induced decrease of urinary calcium excretion was statistically significant in all groups characterized by a Ca/creat ratio $>0.5$. We have used this figure, therefore, as the lower limit for subjects to be identified as 'fast losers' in our study among anticoagulated patients.

It is well known that coumarin derivatives antagonize the effect of vitamin $\mathrm{K}$ on proteins involved in blood coagulation. If these drugs would also counteract vitamin $\mathrm{K}$ action in processes related to calcium metabolism, one might expect them to induce an increase of the urinary calcium excretion in fast losers, or to increase the fraction of fast losers among anticoagulated subjects. A complicating factor in this kind of investigation is the difficulty to find sufficient numbers of participants shortly prior to their starting oral anticoagulant therapy, who can be checked in a longitudinal study before and during the first year of treatment. We have therefore chosen for a cross-sectional study, enabling us the statistical analysis of patients on stable, long-term anticoagulant therapy. Postmenopausal women were selected for the study described in the first part of this paper, because the fraction of fast losers of urinary calcium is known to be high in this group. ${ }^{12}$ 
Preliminary data from our laboratory indicate that the effect may not be restric ted to postmenopausal women, however, but may be found in other fast losers as well (M.H.J. Knapen, unpublished results). In our study among anticoagulated patients we have therefore recorded the numbers of fast losers in four groups differing with respect to age and sex. The data thus obtained were compared to those from age- and sex-matched control groups. An elevated number of fast losers was found in both groups of anticoagulated men as well as in anticoagulated premenopausal women, only in young men the difference with the control group was statistically significant, however. These data indicate that coumarin derivatives may induce a disturbance of the calcium meta bolism, manifesting itself in an elevated number of fast losers of urinary calcium.

No significant effects of vitamin $\mathrm{K}$ antagonists were found in the group at risk for developing osteoporosis: the postmenopausal women. It is well known that at the onset of the menopause, factors like the change of the hormonal status may induce substantial alterations in the calcium and bone metabolism; apparently these factors outweigh the effect of coumarin derivatives. Moreover, the large number of fast losers in the post menopausal control group may obscure relativeIy small anticoagulant-induced effects like those found in men and younger women. Of special interest is the group of young men which showed a significant increase in the number of fast losers. As was the case in both groups of postmenopausal women, a good correlation between the fasting urinary calcium and OHPro excretion $(\mathrm{r}=0.52, \mathrm{p}<0.004)$ was also found among the an ticoagulated young men, indicating that a high urinary calcium excretion was accompanied with a high bone resorption (Figure 4). A long-term increased bone resorption may eventually lead to a decrease of the bone mass, a well known risk factor for de veloping osteoporosis. ${ }^{2}$ Additional indications for a possible hamful effect of oral anticoagulants on bone tissue are provided by two recent studies which both found a decreased bone mineral content in patients on long-term anticoagulant therapy. ${ }^{16,17}$

As yet nothing can be said about the mechanism which underlies a putative regulation of urinary calcium excretion by vitamin $\mathrm{K}$. The data on osteocalcin show that, like vitamin $\mathrm{K}$, also coumarin derivatives can reach the osteoblasts in bone tissue. Their effect may well be explained by an intracellular accumulation of osteocalcin precursors, although a direct inhibition of the osteoblast activity by vitamin $\mathrm{K}$ antagonists cannot be excluded at this time. An altered osteoblast activity could affect the balance between bone formation and resorption leading to an increased calcium loss from bone tissue. It can not be excluded that other (still unknown) vitamin $\mathrm{K}$ dependent proteins found in bone tissue (e.g. MGP), could also be involved in this process. Because vitamin $\mathrm{K}$-dependent carboxylase has 
also been found in renal tubule cells ${ }^{18}$ and membrane-bound Gla-containing proteins have been identified in the renal cortex, ${ }^{19}$ it is also possible that the changes in urinary calcium excretion described in this paper are the result of alterations in renal rather than in bone Gla-proteins. The data presented in this paper justify the start of more elaborate, longitudinal trials in which the urinary calcium excretion and various markers for bone metabolism are measured in humans before and during the first year of treatment with either vitamin $K$ or vitamin $\mathrm{K}$ antagonists.

\section{ACKNOWLEDGMENT}

This research was supported by grant 89.003 from the Dutch Thrombosis Foundation and by grant 28-1150 from the Prevention Fund. The authors wish to thank the management and personnel of the Thrombosis Services of the University Hospital Maastricht and of the De Wever Hospital in Heerlen for their kind collaboration and Dr. C. Degenaar (Department of Clinical Chemistry, University Hospital Maastricht) for performing the calcium and hydroxyproline determinations.

\section{REFERENCES}

1. Olson RE. The function and metabolism of vitamin K. Ann Rev Nutr 1984:4:281-337.

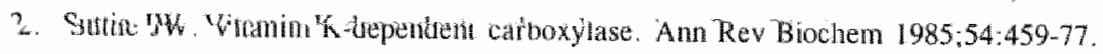

3. Vurmeer $\mathrm{C}, \gamma$-Carboxyglutamate-contaning proteins and the vitanin $\mathrm{K}$-dependent carboxylase Biochem I 1990;266:625-36.

4. Furie B. Furie BC. The molecular basis of blood coagulation. Cell 1988:53:505-18.

5. Proe PA. Otsuka AS, Poser JW, Kristaponis I, Raman N. Characterization of a $\gamma$ carboxyglutam mic acid-contaning protein from bone. Proc Natl Acad Sci USA 1976; 73:1447-51.

6. Hauschka PV. Reid ML. Vitamin $K$ dependence of a calcium-binding protein containing gamma carboxyglutamic acid in chicken bone. J Biol Chem 1978;253:9063-8.

7. Price PA. Urist MR, Otawara $Y$. Matrix Gla protein, a new $\gamma$-carboxyglutamic acid-contaning protein which is associated with the organic marix of bone. Biochem Biophys Res Comm $1983: 117: 765-71$.

8. Gijsbers BMLG. van Hatllem LJM, Soute BAM, Ebberink RHM, vermeer C. Characterization of at Gila-containing protein from calcified luman atherosclerotic plaques. Arteriosclerosis $1990: 10: 991-5$

9. Lian JB. Prien EL Jr, Glimcher MJ, Gallop PM. The presence of protein-bound $\gamma$-carboxyglutamic acid in calcimi-containing renal calculi. J Clin Invest 1977;59:115:-7.

10. Lian JB, Skinner M, Glimcher MJ. Gallop P. The presence of $\gamma$-carboxyglutanic acid in proteins associated witl ectopic calcification. Biochem Bioph Res Comm 1976;73:349-55. 
11. Knapen MHJ, Hamulyak K. Vermeer C. The effect of vitamin $K$ supplementation on circulating osteocalcin (bone Glauprotein) and wrinary calcium excretion. Ann Int Med 1989; 111: 1001-5.

12. Nordin BEC. Diagnostic procedures in disonders of calcium metabolism. Clin Endocrin $1978: 8.55-67$

13. Colton T. Statistics in medicine. Little Brown and Company. Boston 1974

14. Pettifor JM, Benson R. Congenital malformations associated with the administration of oral anticoagulants during pregnancy. I Pediatr 1975:86:459-62.

15. Price PA. Role of vitamin K-dependent proteins in bone metabolism. Am Rev Nutr 1988,8:565. 83.

16. Fiore $\mathrm{CE}$, Tamburino $\mathrm{C}$. Foti $\mathrm{R}$, Grimaldi $\mathrm{D}$. Reduced bone mineral content in patients laking an oral anticoagulant. South Med J 1990:83:538-42.

17. Resch H, Pietschmamn P. Krexner E. Willwonseder R. Decreased peripheral bone mineral content in patients under anticoagulant therapy with phenprocoumon. Eur Heart $\mathbb{1} 1991: 12: 439-41$.

18. Friedman PA, Mitch WE. Silva P. Localization of renal vitamin K-dependent gammaglutanyl carboxyllase to tubule cells. J Biol Chem 1982:257:11037-40.

19. Hauschka PV, Friedman PA, Traverso MP, Gallop PM. Vitamin K-dependent gamma-carboxyglutamatic acid formation by kidney microsomes in witro. Biochem Biophys Res Commun $1976 ; 71: 1207-13$. 



\title{
VITAMIN K-INDUCED CHANGES IN MARKERS FOR OSTEOBLAST ACTIVITY AND URINARY CALCIUM LOSS
}

\author{
Marjo H.J. Knapen', Kon-Siong G. Jie', Karly Hamulyák², and Cees Vermeer ${ }^{1}$ \\ 1 Department of Biochemistry and Cardiovascular Research Institute (CARIM). University of \\ Limburg, The Netherlands \\ 2. Department of Haematology. University Hospital Maastrich
}

\section{SUMMARY}

The objective of this study was to identify subjects in whom vitamin $\mathrm{K}$ has an effect on markers for calcium and bone metabolism, and to detect hitherto unnoticed correlations between vitamin K-induced changes in these markers. Participants in our studies were apparently healthy women, in whom we measured: serum immunoreactive osteocalcin (irOC) before and after adsorption to hydroxyapatite; total serum alkaline phosphatase (T-AP) and bone-specific alkaline phosphatase (B-AP); and fasting urinary calcium and creatinine. We describe a trial among 145 women who were treated with vitamin $\mathrm{K}(1 \mathrm{mg} /$ day) for 2 weeks, and a prospective placebocontrolled trial among two groups each of 70 postmenopausal women with a treatment period of 3 months. It turned out that in elderly women vitamin $\mathrm{K}$ induced increased levels of serum irOC with a high affinity for hydroxyapatite (irOC $\mathrm{C}_{\mathrm{benal}}$ ), whereas that with low affinity (irOC $\mathrm{Crice}_{\text {) }}$ ) remained unaffected. In placebo-treated women the ratio irOC free $/ \mathrm{irOC}_{\text {bernial }}$ shifted from 0.38 to 0.65 around the fiftielh year of age. This shift was not found in vitamin $\mathrm{K}$-treated women. After three months of treatment the vitamin $\mathrm{K}$-induced changes in irOC $\mathrm{C}_{\text {bout }}$ were correlated with changes in $\mathrm{B}-\mathrm{AP}$, whereas irOC $\mathrm{C}_{\text {rec }}$ was correlated to urinary calcium excretion. In fast losers of urinary calcium vitamin $\mathrm{K}$ induced a $30 \%$ decrease of caicium excretion. The hypothesis is put forward that irOC $\mathrm{C}_{\mathrm{ban} w \mathrm{w}}$ may be a marker for bone formation, that serum $i \mathrm{rOC}_{\text {free }}$ may be a marker for bone resorption, whereas the serum irOC $_{\text {ire }} / \mathrm{irOC}_{\text {bound }}$ ratio may become a marker for skeletal remodeling. It is concluded that vitamin $K$ administration may help to reduce urinary calcium loss in postmenopausal women, notably in the fast losers of calcium. The ratio irOC $_{\text {irve }} / \mathrm{irOC}_{\mathrm{bouna}}$ provides more information than total irOC and may become a practical marker for bone metabolism. 


\section{INTRODUCTION}

Vitamin $K$ functions as the coenzyme for $\gamma$-glutamylcarboxylase, a microsomal enzyme mediating the posttranslational carboxylation of protein-bound glutamate into $\gamma$-carboxyglutamate (Gla) residues. ${ }^{1.2,3}$ Gla-containing proteins are found in body fluids (plasma, urine), ${ }^{4,5}$ and in calcified tissues (bone, hardened atherosclerotic plaques); ${ }^{6,7.8}$ well-known examples are the vitamin K-dependent blood coagulation factors and the bone Gla-proteins osteocalcin (OC) and matrix Gla-protein (MGP). In all these proteins the only known function of Gla is the binding of calcium ions. Blood coagulation is the only process in which the role of Gla-proteins has been well established, and in which their function has been described to a molecular level. Accumulating evidence indicates, however, that calcium metabolism is a second physiological process in which Gla-proteins are involved. ${ }^{7}$

In a previous paper we have reported that in a selected group of women (nuns between 55 and 75 years of age) the hydroxyapatite binding capacity of the circulating immunoreactive osteocalcin (irOC) was abnormally low compared to premenopausal women. ${ }^{10}$ Explanations for this phenomenon are that either the Gla-content of the irOC is suboptimal or that the immunoreactive material contains a partly degradled form of $\mathrm{OC}$, from which the Gla-residues have been split off. Administration of vitamin $\mathrm{K}$ ( $1 \mathrm{mg}$ daily for 14 days) resulted in an increase of both the concentration and the hydroxyapatite binding capacity of circulating irOC. In parallel the treatment induced a significant decrease of the fasting urinary calcium excretion, notably in the fast losers of calcium (calcium/creatinine ratio $>0.5$ ). To test the universality of these findings we have extended our studies to a group of civilian. women. In a first trial we investigated the occurrence and age-dependency of the vitamin K-induced effects on serum irOC. Second, a longer study in a selected age group was undertaken to assess the duration of the vitamin $\mathrm{K}$-induced effects. To obtain more insight in the value of serum irOC as a marker for bone metabolism, the irOC fractions with high affinity for hydroxyapatite $\left(\mathrm{irOC}_{\text {bound }}\right.$ ) and that with low affinity (irOC $\mathrm{frev}_{\text {) }}$ ) were quantified separately in all cases.

\section{MATERIALS AND METHODS}

\section{Subjects}

Apparently healthy, physically active women were recruited via a local newspaper call. All had normal serum calcium levels, as well as normal liver and renal functions. Exclusion criteria were malnutrition, a history of recent fractures or metabolic bone disease, and medication known to affect calcium and bone metabolism or vitamin $\mathrm{K}$ status. Solubilized vitamin $\mathrm{K}_{1}\left(\mathrm{Konakion}^{\left({ }^{(}\right)}\right.$) was obtained from HoffmannLa Roche (Basle, Switzerland) and distributed among the participants in drop-bottles 
containing $20 \mathrm{mg} / \mathrm{mL}$, the placebo was constituted of the same solvent as the vitamin $\mathrm{K}$ preparation. One drop of the vitamin ( $\mathrm{mg}$ ) or placebo was taken orally by mixing it with tap water immediately before drinking it. The study was approved by the local ethics committee, and informed consent was obtained from all subjects, according to the institutional guidelines.

\section{Tests}

Fasting blood samples were collected by venipuncture between 8 and 10 AM. The samples were left at room temperature for 2 hours and after a short centrifugation step serum was immediately frozen at $-80^{\circ} \mathrm{C}$ until use. Serum irOC concentrations were assessed by radioimmunoassay (Incstar, Stillwater, MI) before (total irOC) and after $\left(\mathrm{rOC} \mathrm{C}_{\text {tree }}\right.$ ) extraction with $100 \mathrm{mg} / \mathrm{mL}$ hydroxyapatite, 10 and $1 \mathrm{irC}_{\text {bound }}$ was calculated from the difference between these two figures. "The inter- and intra-assay coefficients of variation of serum total irOC were 10 and $5 \%$, respectively. Analysis of total alkaline phosphatase activity (T-AP) was performed in a Cobas centrifugal analyzer (Roche) with a commercial kit (Roche). The inter-and intra-assay variation coefficients were 2 and $1.5 \%$, respectively. Bone specific alkaline phosphatase activity (B-AP) was measured according to Behr and Barnert," with inter and intra-assay variation coefficients of 7 and $5 \%$.

To exclude dietary influences, urine was collected during the last 2 h of a 16 h lasting period, as recommended by Nordin." ${ }^{2}$ The samples were acidified ( $\mathrm{pH} 1$ ) and stored at $-30^{\circ} \mathrm{C}$ until serial testing. Urinary calcium concentrations were determined with an atomic absorption spectrophotometer (Perkin Elmer, Norwalk, CN), and creatinine with a commercial kit (Roche). The urinary calcium excretion is expressed throughout this paper as the molar ratio between calcium and creatinine in the fasting urine samples. Fast losers of urinary calcium are defined as those with a calcium/creatinine ratio $>0.5$, nomal losers as those with a ratio between 0.15 and 0.5

\section{Data analysis}

For both trials reported, statistical analysis was performed with the software package SPSS/PC + version 3.1 (SPSS Inc, Chicago, III). Changes berween groups and within one group (second trial) were detected with the two-sided unpaired and paired Student's $t$-test, respectively; differences were considered to be significant if $p<$ 0.05 . Relations between wariables were tested by least-square linear regression. All data are expressed as the mean $\pm \mathrm{SE}$. Only those subjects who completed the protocol without omissions were included in the analysis of correlation between the different parameters tested. 


\section{RESULTS}

Effects of witamin $K$ on circulating osteocalcin: relation with age

In a first study among 145 women between 20 and 85 years of age we have measured whether the vitamin $\mathrm{K}$-induced effects on serum irOC are related to age. Participants were assembled in age groups differing from each other by five years. Each group consisted of at least 10 women. Blood was taken before and after a two week period during which the participants received vitamin $\mathrm{K}(1 \mathrm{mg} / \mathrm{day})$.

Before vitamin $\mathrm{K}$ treatment the mean level of total iroC in this group was 3.47 ( \pm 0.10$) \mathrm{ng} / \mathrm{mL}$, but as can be seen in Figure $1 \mathrm{~A}$, this marker varied in the different age groups. In the age groups between 20 and 50 there was a gradual increase of serum irOC with age. The increase seemed to accelerate around the 50th year of life, but irOC levels sharply dropped after the age of 60 . Treatment of the participants with vitamin $\mathrm{K}$ for two weeks resulted in an increase of the circulating total irOC levels in all groups, but this increase was only statistically significant for those older than 45 .

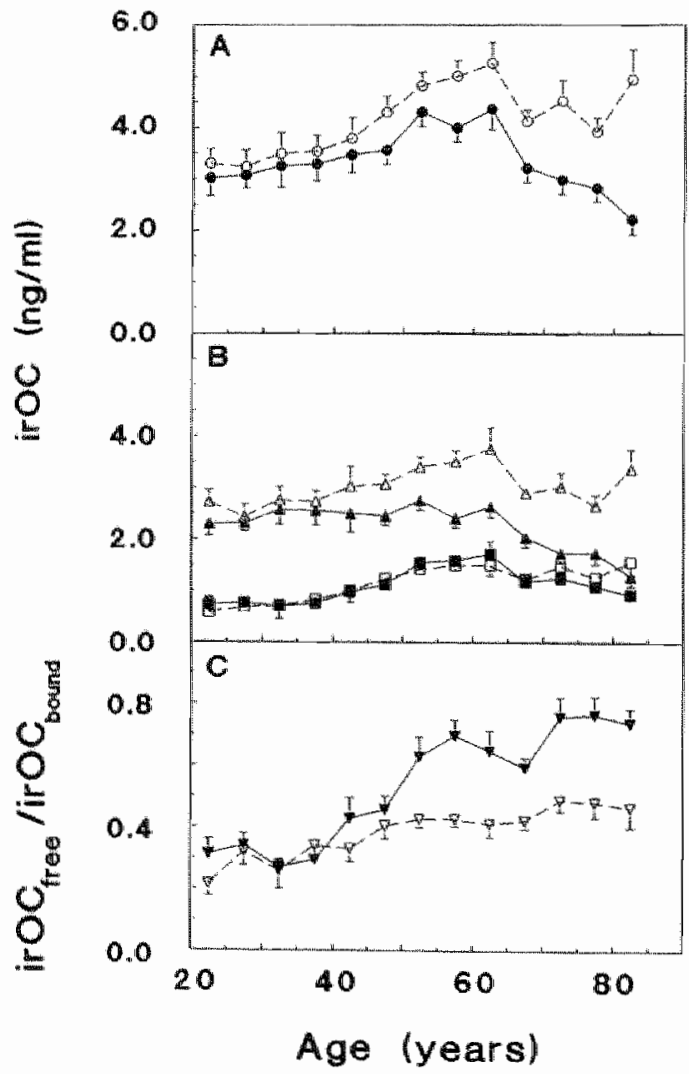

Figure 1. Age-dependent chan ges in serum asteocalcin. Par. thipants were divided into 13 age groups, each consisting of at least 10 women. $(A)$ totat irOC and (B) irochree (squares) and irocbound (rriangles) were meastured before fclosed symbols) and after (open symbols) 2 weeks of vitamin $\mathbb{K}$ adminismration. The ratio between irocfreeplirocbound is given in C. All resulss are expressed as the neans for each age group \pm $S E$. The effect of wiamin $K$ on roral serm irOC (A) and on irocbound (B) was sigmificam $(P<0.05)$ in all groups older than 45 years, that on irocfreelirocbound (C) was significant in all groups older than 50 years. 
Table 1: Osieocalcin markers before and after vitamin $K$ treatmen in women younger than 50 years $(n=67)$ and older than 50 years $(n=78)$

\begin{tabular}{|c|c|c|c|c|c|c|}
\hline Marker & Age group & $\begin{array}{l}\text { Before treat - } \\
\text { ment }\end{array}$ & $\mathbb{P}_{\text {agd }}$ & $P_{\text {ureat }}$ & After treament & $P_{x y c}$ \\
\hline \multirow[t]{2}{*}{$\mathrm{irOC}_{\text {toust }}$} & $<50$ & $3.18 \pm 0.15$ & $<0.05$ & $<0.005$ & $3.87 \pm 0.21$ & $<0.005$ \\
\hline & $>50$ & $3.62 \pm 0.13$ & & $<0.005$ & $4.63 \pm 0.13$ & \\
\hline \multirow[t]{2}{*}{$\mathrm{irOC}_{\text {iree }}$} & $<50$ & $0.89 \pm 0.07$ & $\begin{array}{l}<0.00 \\
5\end{array}$ & & $0.95 \pm 0.15$ & $<0.005$ \\
\hline & $>50$ & $1.37 \pm 0.05$ & & & $1.40 \pm 0.05$ & \\
\hline \multirow[t]{2}{*}{$i r O C_{\text {lownd }}$} & $<50$ & $2.30 \pm 0.10$ & & $<0.005$ & $2.92 \pm 0.09$ & \\
\hline & $>50$ & $2.25 \pm 0.09$ & & $<0.005$ & $3.23 \pm 0.09$ & \\
\hline \multirow[t]{2}{*}{ ir $\mathrm{OC}_{\text {freestrandal }}$} & $<50$ & $0.39 \pm 0.03$ & $\begin{array}{l}<0.00 \\
5\end{array}$ & & $0.33 \pm 0.03$ & $<0.005$ \\
\hline & $>50$ & $0.67 \pm 0.03$ & & $<0.005$ & $0.44=0.01$ & \\
\hline
\end{tabular}

All results are given as the means $\pm S . E . P_{a g e}$ stands for the significance of the difference of one marker between two age groups (2-sided unpaired Student"s it-test), $P_{\text {trea }}$ stands for the sigmificance of the dif-ference before and after vitannin $K$ treatment in one age group (2-sided paired Student's $i$-test).

Total irOC was subdivided into irOC $\mathrm{bounu}_{\text {and }}$ and $\mathrm{rOC}_{\text {tree }}$ (Figure 1B), which showed that the age-related increase of serum iroC was almost completely due to irOC $\mathrm{C}_{\text {free }}$, whereas the decrease after the age of 64 was caused by the substantial decrease of irOC $\mathrm{C}_{\text {bound }}$. Also, it appeared that the effect of vitamin $\mathbb{K}$ remained almost completely

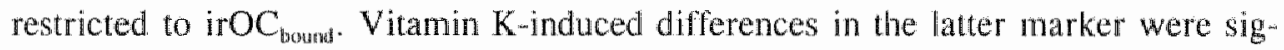
nificant in all groups of 45 years and older ( $p<0.01$ for all age groups). The mean effect of vitamin $K$ in the women older than 50 years was an increase of the irOC $_{\text {bounul }}$ from $2.25( \pm 0.08)$ to $3.23( \pm 0.09) \mathrm{ng} / \mathrm{ml}$. Further details are summarized in Table 1.

In Figure $1 \mathrm{C}$ we have plotted the ratio between irOC $\mathrm{C}_{\text {free }}$ and irOC $\mathrm{C}_{\text {boum }}$ as a function of age. Before treatment with vitamin $\mathrm{K}$ this ratio amounted to $0.39( \pm 0.03) \mathrm{in}$ women younger than 50 years, but it increased to $0.67( \pm 0.03)$ after the age of 50 . The difference between both age groups is significant at $\mathrm{p}<0.005$. After treatment of all women with vitamin $\mathrm{K}$ the $\mathrm{irOC}_{\mathrm{frec}} / \mathrm{irOC}_{\mathrm{bxw}}$ ratios of the younger women remained unchanged, but those of the elderly participants decreased to values which approached the premenopausal values.

To obtain more information about the nature of $\mathrm{irOC}_{\text {boun }}$ and irOC $_{\text {reec }}$ five serum samples from different subjects were dialyzed against buffered saline ( $\mathrm{pH}$ 7.4) for 1 


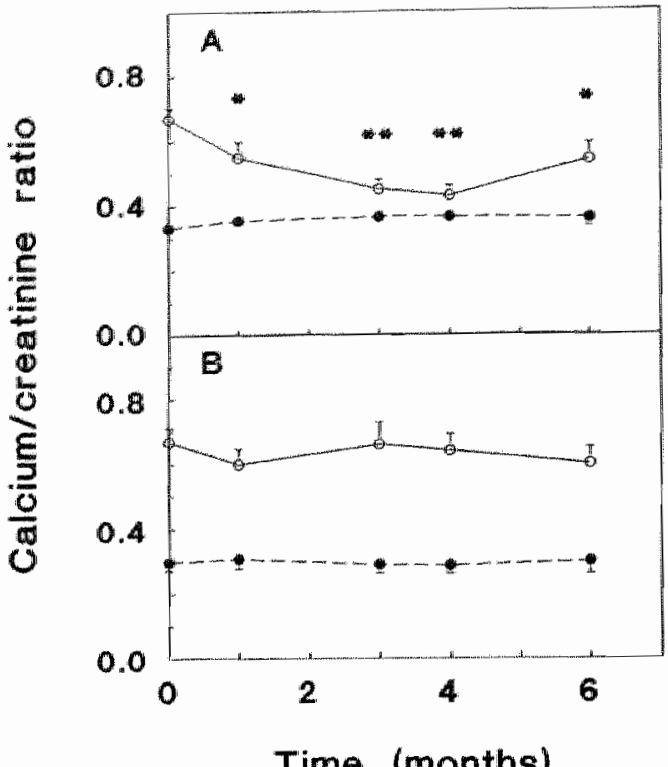

Figure 2. Prolonged ireatment of postmenopausal wamen 150 85 yr) with vitamin $K$. Fast (open symbols) and nomal (closed symbols) losers of urinary calcium were assembled and treated with elither vitamin $K$ (A) or placebo (B). : $P<$ 0.05 , * : $P<0.005$. All data are givers $\pm S E$.

Time (months)

h at $4{ }^{\circ} \mathrm{C}$. The molecular weight cutoff value of the dialysis membrane was $3.5 \mathrm{kDa}$, which was found to be sufficient for preventing the loss of intact osteocalcin. Identical samples were incubated in plastic tubes at $4{ }^{\circ} \mathrm{C}$ for the same period, and it was ascertained that both irOC $\mathrm{C}_{\text {bound }}$ and irOC $_{\text {free }}$ remained unchanged in these control samples. In the dialyzed samples at least $50 \%$ of the irOC $\mathrm{free}_{\text {fed }}$ had disappeared within

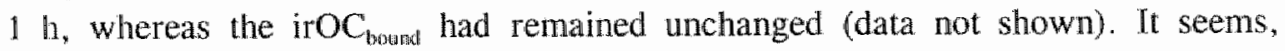
therefore, that in elderly women at least a major part of the circulating $\operatorname{irOC}_{\text {free }}$ has a reduced size.

Correlation between serum osteocalcin and other markers for bone metabolism From the first trial it became apparent that the largest effects of vitamin $\mathrm{K}$ administration were found in the age group older than 50 years. To further identify subjects with a high response to vitamin $\mathbb{K}$ treatment, and to be able to correlate both forms of serum osteocalcin with other markers for calcium and bone metabolism, a second trial was started for which 834 apparently healthy women between the age of 50 and 80 years were recruited. Based on the calcium/creatinine ratios in their fasting urine, 70 fas6t losers of urinary calcium, as well as an age-matched group of normal losers were selected. Both normal and fast losers were subdivided further into two similarly sized, age-matched groups: one received vitamin K-treatment $(1 \mathrm{mg} /$ day for three months) and the other received a placebo. Blood and urine were collected at the outset, and at 1, 3, 4, and 6 months after starting the treatment. From the 140 participants thus selected 111 attended all examinations and completed the protocol: 58 in the fast losers group (30 vitamin K-treated subjects and 28 placebo-treated 


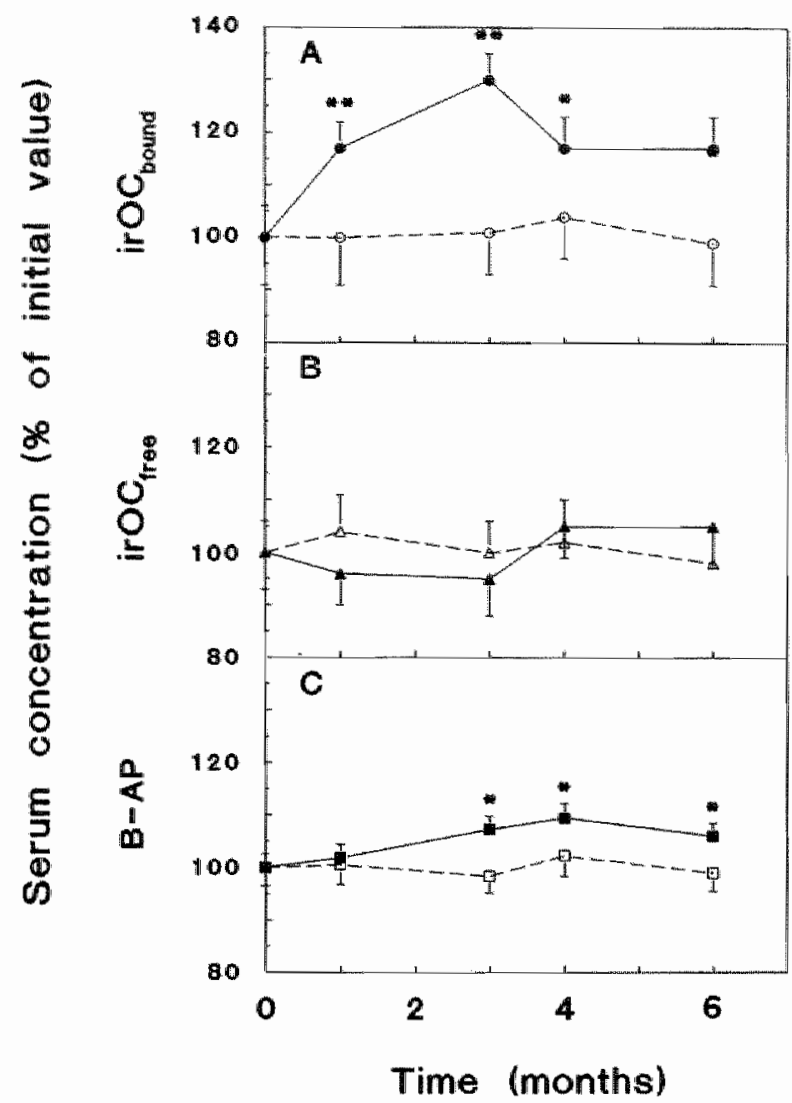

Aigure 3. Viromin Kunduced eftects on warious serum markers for bone metabolism. Mankers tested were: irocbond (A), irocfree (B), and B.AP (C). Closed symbols: witamin $K$ treated groups; open symbols: placebo-sreated groups. All dau are expressed as a percentage of the starting walues \pm SE. Further details are as described ith the legend to Figure 2 .

Time (months)

ones), and 53 in the normal losers group ( 28 vitamin $\mathrm{K}$ - and 25 placebo-treated subjects).

After $\mathbb{1}$ month of treatment the mean urinary calcium loss in the vitamin $\mathrm{K}$ treated group of fast losers had decreased, whereas no effect was found in the normal losers group (Figure 2). Also, in both placebo-treated groups the urinary calcium loss remained constant during the trial. In the fast losers groups the difference between vitamin $K$ - and placebo-treated subjects was significant $(p<0.01)$ after 1 month, continued during the two subsequent months $(p<0.005$, mean decrease: 30 $\%)$, and gradually reversed after the treatment had stopped. In all groups the creatinine concentration in the samples had remained constant during the entire study period, and changes in the calcium/creatinine ratio were solely due to variations in the calcium excretion. These data demonstrate, therefore, that the effect of vitamin $K$ administration on urinary calcium loss is most prominently seen among the fast losers of urinary calcium. 
The effects of the treatment on serum irOC and bone-specific alkaline phosphatase (B-AP) are shown in Figure 3. Also, in this trial the serum iroC boantit significantly increased as a result of the vitamin $K$ treatment $(p<0.01$, Figure $3 A$ ).

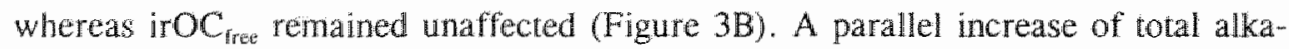
line phosphatase (data not shown) could be attributed completely to a rise of the BAP levels $(p<0.01$, Figure $3 C)$. These changes lasted for the entire treatment period, and gradually reversed after the treatment was stopped. After 3 months of treatment the vitamin $\mathrm{K}$-induced changes in rOC $_{\text {foxum }}$ and $\mathrm{B}-\mathrm{AP}$ were correlated, with $r$ and $p$ values of 0.541 and 0.002 , respectively.

Subsequently we have tested whether serum irOC might be correlated in some way to urinary calcium loss. For these calculations the pre-treatment data of both the vitamin $\mathrm{K}$ and the placebo group were combined, and it turned out that the urinary calcium/creatinine ratio was positively correlated with irOC $\mathrm{C}_{\text {free }}(\mathrm{r}=0.410, \mathrm{p}=$

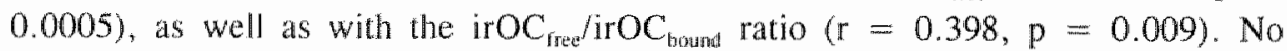
correlation was found between urinary calcium loss and either irOC $\mathrm{C}_{\text {bound }}$ or B-AP. After vitamin $\mathrm{K}$ treatment both the $\mathrm{irOC}_{\text {free }} / \mathrm{irOC}_{\text {bound }}$ as well as the calcium/creatinine ratio had shifted to lower values, and no correlation with calcium excretion was found at that time. On the basis of these data it is to be expected that iroc $\mathrm{C}_{\mathrm{free}}$ in a population of fast losers of urinary calcium is higher than in a comparable group of nomal losers. We have tested this assumption by comparing the data from all participants before the start of the second trial, and we found irOC $C_{\text {iree }}$ levels of $1.30 \pm$ 0.07 and $1.78 \pm 0.10 \mathrm{ng} / \mathrm{ml}$ for the normal and the fast losers group, respectively. This difference was significant at $\mathrm{p}<0.05$.

\section{DISCUSSION}

In the literature there is no consensus about the relation between serum iroC and age. Whereas some authors report a continuous rise in irOC in women older than $40,{ }^{13.14}$ others claimed this marker to be constant ${ }^{15}$ or to decrease at increasing age." In this paper we demonstrate that in adult women the serum level of total serum irOC gradually increases until the age of about 55 years, but it sharply decreases in the age groups older than 60 . Further analysis showed that the curve for total irOC was composed of two apparently independent variables: irOC $\mathrm{C}_{\text {free }}$ and irOC $_{\text {kxum }}$. Whereas irOC $\mathrm{C}_{\text {fres }}$ exhibited an age-dependent increase which was most prominent between 50 and 60 , the irOC $C_{\text {bound }}$ remained nearly constant until the age group 60-65, and then sharply decreased at later ages. The ratio $\mathrm{irOC}_{\text {free }} / \mathrm{irOC}_{\text {bound }}$ remained low until the age of 45 , but nearly doubled immediately afterwards. (Figure IC). Vitamin $\mathrm{K}$ administration only affected the serum levels of irOC $\mathrm{C}_{\text {bound }}$. The rate at which this effect took place (within 14 days), and the fact that the vitamin $\mathrm{K}$ induced changes of $\mathrm{irOC}_{\text {brumbl }}$ were strongly correlated to changes in the serum B-AP 
suggest that the circulating irOC $C_{\text {beurd }}$ originates from de novo synthesis by the osteoblasts. This has been proposed earlier for total serum irOC. ${ }^{17}$ Moreover, the effect of vitamin $\mathrm{K}$ on B-AP suggests a direct effect of this vitamin on osteoblast activity. Similar effects of vitamin $\mathrm{K}$ have recently been reported for osteoblastic cells in vitro, which also responded to the vitamin with an increase of alkaline phosphatase production. ${ }^{18}$ The physiological importance of these observations is unclear at this time.

It was striking that iroC $\mathrm{C}_{\text {fre }}$ was insensitive for vitamin $\mathrm{K}$. This poses serious questions to the earlier supposition that irOC $\mathrm{C}_{\text {free }}$ is a partly or non-carboxylated form of osteocalcin. ${ }^{10.19}$ An alternative explanation might be that irOC free has lost its Gladomain after limited proteolysis, either in serum or in bone. Preliminary experiments indicating a reduced mass for irOC $_{\text {free }}$ support the latter hypothesis. Moreover, the relative insensitivity of irOC $\mathrm{C}_{\text {ire }}$ for vitamin $\mathrm{K}$ suggests that it does not originate from de novo synthesis, but from an allready existing pool. It seems probable, therefore, that at least part of the circulating irOC $\mathrm{C}_{\text {free }}$ is set free from bone tissue during osteoclastic resorption. This hypothesis implies that the proteolytic fragments are still detectable by radioimmunoassay, and the extent to which these fragments are recognized may be the major difference between the various commercial kits. More details about the nature and origin of both forms of osteocalcin may be obtained after twosite immunoassays based on well-defined monoclonal antibodies have become available.

It is well known that around the onset of the menopause the urinary calcium excretion and the loss of bone mass may increase considerably. ${ }^{20}$ It has been observed that around menopause irOC $\mathrm{C}_{\text {iree }} / \mathrm{irOC}_{\text {beund }}$ ratio increases, and that there is a correlation between irOC $\mathrm{Crre}_{\text {fen }}$ and urinary calcium loss; both suggest that irOC $\mathrm{C}_{\text {tree }}$ is somehow related to bone degradation. Here we want to put forward the hypothesis that rather than total irOC, the serum concentration of irOC $\mathrm{C}_{\text {beund }}$ is a marker for osteoblast activity, whereas serum irOC $\mathrm{C}_{\text {free }}$ levels reflect osteoclast activity. If so, the ratio between irOC $\mathrm{Cree}_{\text {fre }} / \mathrm{irOC}_{\text {brumd }}$ forms a marker for the metabolic state of bone, and it may become an important diagnostic tool to identify subjects at risk for developing osteoporosis. Although in most women older than 50 years this ratio reacted strongly on vitamin $\mathrm{K}$ administration, only in fast losers of calcium did the vitamin have a significant effect on urinary calcium loss. This demonstrates that vitamin $\mathrm{K}$ status is not directly correlated with calcium excretion, but that low nutritional intake or poor intestinal absorption of vitamin $\mathbb{K}$ may be risk factors for increased urinary calcium loss,

As can be seen in Figures 2 and 3, the effect of vitamin $\mathrm{K}$ on irOC $\mathrm{C}_{\text {bound }}$, B-AP, and calcium/creatinine ratio was maximal after 3 months of treatment. It is also clear that for all three markers the effect was still detectable 3 months after the treatment had been stopped. Because the plasma half-life time of pharmacological doses of vitamin $\mathrm{K}$ is about 2 hours, we assume that at least part of the vitamin administered 
in our experiments had been stored in phospholipid membranes or adipose tissue and set free therefrom during the first few month following the treatment period.

Whether an insufficient vitamin $K$ status may lead to an accelerated loss of bone mass cannot be concluded from our data. The first indications in favor of this sug gestion may be found in the recent observation of Akiba et al., who showed that loss of bone mass could be retarded in haemodialysis patients with a low-turnover bone disease by vitamin $K$ administration, ${ }^{21}$ and by papers from two independent groups, showing that patients exposed to long-term treatment with vitamin $K$ antagonists have a significanily Jower bone mass than age- and sex-matched controls. ${ }^{22.23}$ As yet there are no indications for a regulation by Gla-proteins of intestinal calcium absorption or glomerular filtration. A prospective vitamin $\mathrm{K}$ intervention study including yearly bone mass determinations (DEXA-scan) is in progress in our laboratory.

\section{ACKNOWLEDGMENT}

The authors wish to thank Mrs. B.L.M.G. Gijsbers for her technical assistance. This study was supported by grants 28-1150 and 28-2140 from the Dutch Prevention Fund.

\section{REFERENCES}

1. Vermeer $C$. Gammacarboxyglutamate-containing proteins and the vitamin $K$-dependent carboxylase. Biochem J 1990:266:625-6.

2. Sutric JW. Vitamin K-dlependen carboxylase. Annu Rev Biochem 1985:54:459-77.

3. Otson RE. The function and metabolism of vitamin K. Annu Rev Nutr 1984:4:281-337

4. Furte B, Furie BC. The molecular basis of blood coagulation. Cell 1988;53:505-18.

5. Nakagawa Y. Abram V, Kézdy Fl, Kaiser ET, Coe FL. Purification and characterization of the principal inhibitor of calcium oxalate monohydrate crystal growth in human urine. $J$ Biol Chem $1983 ; 258: 12594-600$.

6. Price PA. Role of vitamin K-dependent proteins in bone metabolism. Annu Rew Nutr 1988;8: $565-83$

7. Hauschka PV. Lian JB, Cole DEC, Gundberg CM. Osreocalcin and matrix Gla protein: vitamin $\mathrm{K}$ dependent proteins in bone. Phys Rev 1989;69;990-1047.

8. Gijsbers BLMG, van Haarlem LJM, Sorte BAM, Ebberink RHM, Vermeer C. Characterization of Gla-containing protein from calcified human atherosclerotic plaques. Arteriosclerosis $1990 ; 10: 991-5$.

9. Vermeer $C$, Hamulyák $\mathbb{K}$. Pathophysiology of vitamin $\mathrm{K}$ deficiency and oral anticoagulants. Thromb Haemostas 1991:66:153-9.

10. Knapen MHJ. Mamulyák K, Vermeer $\mathrm{C}$. The effect of vitamin $\mathrm{K}$ supplementation on circulating osteacalcin (bone Gla-protein) and urinary calcium excretion. Ann Int Med 1989;111:1001-5.

11. Behr W. Barnert J. Quantification of bone alkaline phosphatase in serum by precipitation with wheat-germ lectin: a simplified method and its clinical plausibility. Clin Chem 1986:32:1960-6. 
12. Nordin BEC. Diagnostic procedures in disorders of calcium metabolism. Clin Endoct 1978:8:55 67.

13. Delmas PD. Stenner P. Heinz W. Wahner K, Mann KG. Increase in semum bone ganma-carboxyglutamic acid protein with aging in women. Implications for the mechanism of age-related bone loss. II Clin Invest $1983 ; 71: 1316 \% 21$.

14. Epstein S, Poser JW, McClintock R, Johnston CC. Bryce $G$. Hui S. Differences in serum bone gla protein with age and sex. Lancet 1984,1:307-10.

15. Catherwood BD, Marcus $\mathrm{R}$, Madvig P, Cheung AK. Determinants of bone gamma-carboxyglutamic acid-containing protein in plasma of healthy aging subjects. Bone 1985:6:9-13.

16. Ismail F, Epstein S, Pacifici R, Droke D, Thomas SB, Avioli LV. Serum bonte Gla protein (BGP) and other markers of bone mineral metabolism in posmenopausal osteoporosis. Calcif Tissue Int $1986: 39: 230-3$.

17. Price PA, Williamson MK, Lothringer JW. Origin of the vitamin K-dependent bone protein found in plasma and its clearance by kidney and bone. J Biol Chem 1981;256:12760-6.

18. Akedo $Y$, Hosoi $T$, Inoue $S$, Ikegani A, Mizuno $Y$, Kanneki M, Nakamura T, Ouchi $Y$, Orimo $H$. Vitamin $K_{2}$ modulates proliferation and function of osteoblastic cells in viro. Biochem Biophys Res Commun 1992;187:814-20.

19. Plantalech $L$. Guillaumont $M$, Vergnaud $P$, Leclercq $M$, Delmas $P D$. Impaiment of gamma carboxylation of circulating osteocalcin (bone Gla protein) in elderly women. I Bone Miner Res $1991 ; 6: 1211-6$.

20. Nordin BEC, Heaney RP. Calcium supplementation of the diet: justified by present evidence. Brit Med I 1990;300:1056-60.

21. Akiba T, Kurihara $S$, Tachibana $K$, Kuwahara M, Sakamoto $H$, Yoneshima H, Marumo F. Vitamin $K(\mathrm{~K})$ increased bone mass $(\mathrm{BM})$ in hemodialysis patients (Pts) with low-lurnover bone disease (LTOBD). I Am Soc Nephrol 1991:2:608

22. Fiore CE, Tamburino $C$, Foti $R$, Grimaldi D. Reduced bone mineral content in patients taking oral anticoagulant. South Med J 1990;83:538-42.

23. Resch $H$, Pieischmann $P$, Krexner $E$, Willwonseder R. Decreased peripheral bone mineral content in patients under anticoagulant therapy with phenprocoumon. Eur Heart J 1991:12:439-41. 


\section{EFFICIENCY OF PHYLLOQUINONE (VITAMIN $K_{1}$ ) ABSORPTION FROM SPINACH IN HUMAN VOLUNTEERS}

Kon-Siong G. Jie, Birgit L.M.G. Gijsbers, and Cees Vermeer

Department of Biochemistry and Cardiovascular Research Institute Maastricht (CARIM), University of Limburg, Maastricht. The Netherlands

\section{SUMMARY}

The human vitamin $\mathbb{K}$ requirement is not precisely known, the minimal requirement is, however, often assumed to be between 0.5 and $1 \mu \mathrm{g}$ per $\mathrm{kg}$ body weight. In this paper we have addressed the question of the extent the which intestinal absorption of vitamin $\mathrm{K}_{1}$ (phylloquinone) is influenced by the form in which the vitamer is consumed. The experimental group was formed by five healthy volunteers who received the phylloquinone after an overnight fast. On the first day of three successive weeks the participants consumed $1 \mathrm{mg}$ of phylloquinone, either in the form of a pharmaceutical preparation (Konakion"), in the form of spinach + butter, or as spinach without additives. It turned out that circulating phylloquinone levels after consuming spinach with and without butter were substantially lower ( 7.5 and 24.3 fold, respectively) than those after taking the pharmaceutical concentrate. Moreover the intestinal absorption of phylloquinone from the vegetables was 1.5 times slower than from Konakion". It is concluded that the absorption of membrane-bound vitamin $\mathrm{K}$ is extremely poor and may depend on food additives, notably fat. The bioavailability of nutritional vitamin $\mathrm{K}$ is much lower than what is generally assumed, and depends on the form in which the vitamin is ingested. These new insights may lead to a revision of the recommended daily intake for vitamin $K$. 


\section{INTRODUCTION}

Vitamin $\mathrm{K}$ is a group name for a number of closely related compounds which may serve as a cofactor for the mammalian microsomal enzyme $\gamma$-glutamylcarboxylase. This enzyme catalyses the posttranslational conversion of glutamate into $\gamma$-carboxyglutamate (Gla) residues at well-defined sites in a limited number of proteins, ", If not specified further the term 'vitamin $\mathrm{K}$ ' will be used for all compounds possessing cofactor activity for $\gamma$-glutamylcarboxylase. Gla-containing proteins have a regulatory function in blood coagulation, ${ }^{3}$ bone metabolism, ${ }_{3}^{4}$ and possibly also in cell growth. ${ }^{5}$ Potential sources of vitamin $\mathrm{K}$ are nutrition $^{6,7.8}$ and the intestinal flora, ${ }^{9}$ but accumulating data suggests that the bioavailability of menaquinones produced in the colon is very poor. ${ }^{10,11,12} \mathrm{It}$ seems that it is only after oral ingestion, that the various forms of vitamin $K$ are absorbed, notably in the small intestine.

The main dietary sources of vitamin $K$ are green vegetables (which exclusively contain phylloquinone) and dairy produce, in which a mixture of phylloquinone and menaquinones is found..$^{6.7 .8 .13}$ In this respect it is important to notice that a) green leafy vegetables contain about 100 times more vitamin $\mathrm{K}$ than does cow's milk, ${ }^{6}$ and b) that in green plants vitamin $K$ is tightly bound to the thylakoid membranes of the chloroplasts, ${ }^{14}$ whereas in dairy produce it is dissolved in the fat fraction. In the case of a normal bile function it may be assumed that the intestinal absorption of vitamin $\mathrm{K}$ from dairy produce is nearly complete. The extent to which phylloquinone is extracted and absorbed from green vegetables is, however, less clear. In this paper we describe the development, in human volunteers, of a standard protocol for measuring the intestinal absorption of vitamin $\mathrm{K}$ from cooked spinach, and investigate how the simultaneous consumption of fat affects this process.

\section{MATERIALS AND METHODS}

\section{Experimental design}

The three different vitamin $K$ regimens described below were given on the first day of three successive weeks. Five healthy volunteers ( 3 men and 2 women, 2545 years old) entered the experiments after an overnight fast. All five volunteers included in our experiment were subjected to the same nutritional regimen starting on the same day. In each case an oral dose of $1 \mathrm{mg}$ of phylloquinone was laken at $8 \mathrm{a} . \mathrm{m}$., either in the form of a detergent-solubilized pharmaceutical concentrate (Konakion", week 1 ), from $227 \mathrm{~g}$ of spinach $+25 \mathrm{~g}$ of butter (week 
2), or from $227 \mathrm{~g}$ of spinach without further additives (week 3 ). At noon of the experimental day one meal was allowed, which was low in both fat and vitamin $\mathrm{K}$ (toast, marmalade, peeled bananas and apples, orange juice and water). Food restriction was continued until $10 \mathrm{~h}$ after vitamin $\mathrm{K}$ ingestion. Blood $(10 \mathrm{ml})$ was taken by venipuncture to prepare serum every hour during the first 10 hours of the experimental day, and the next morning $(t=24 \mathrm{~h})$. The serum samples were subdivided into $1 \mathrm{ml}$ aliquots and kept frozen and protected from light until serial vitamin $\mathrm{K}$ determination. The protocol of this study was approved by the Medical Ethics Committee of the University Hospital / Faculty of Medicine, University of Limburg, Maastricht.

\section{Materials}

Detergent-solubilized phylloquinone (Konakion") was from Hoffmann-La Roche (Basle, Switzerland), spinach was purchased as a commercially prepared, deepfrozen product. Menaquinone-6 (MK-6) was a kind gift from Roche. Silica Seppack cartridges were purchased from Millipore (Milford, MA). All solvents and chemicals were of the highest purity commercially available.

\section{Vitamin $K$ analysis}

Serum vitamin $\mathrm{K}$ was determined as reported by, ${ }^{15}$ with fluorometric detection after electrochemical reduction as proposed by Thijssen et $a l^{16}$ In short, after adding an internal standard (MK-6, $1 \mathrm{ng}$ per $\mathrm{ml}$ of serum), sera were extracted twice with hexane, and the pooled hexane phases were evaporized, dissolved in a small volume of hexane, and fractionated on a sillica sep-pack column. The fraction containing vitamin $\mathrm{K}$ was than purified further on a semi-preparative silica straight phase column (Phase Separations, Deeside, U.K.) by high performance liquid chromatography (HPLC). Quantitative analysis of vitamin $\mathrm{K}$ was performed by isocratic chromatography on an Econosphere $C_{1:}$ reversed phase column (Alltech, Deerfield, IL) in a mixture of $88.5 \%(\mathrm{v} / \mathrm{v})$ methanol, $10 \%(\mathrm{v} / \mathrm{v})$ isopropanol, $1.5 \%(\mathrm{v} / \mathrm{v})$ water and $0.045 \%(\mathrm{v} / \mathrm{v})$ tetramethylammonium octahydrotriborate. The effluent of the column was reduced with a model 5010 analytical cell (Environmental Sciences Associates, Bedford, MA), and analyzed with a Jasco 821-FP spectrofluorometric detector (Separations Analytical Instruments, Hendrik Ido Ambacht, The Netherlands). For the extraction of vitamin $\mathrm{K}$ from spinach, $10 \mathrm{~g}$ of cooked vegetables (wet weight) were mixed with $1 \mathrm{ml}$ of acetone and ground with $0.5 \mathrm{~g}$ of sand. Subsequently $100 \mathrm{ml}$ of acetone was mixed with the homogenate and shaken for $30 \mathrm{~min}$. After the addition of $100 \mathrm{ml}$ of water, the solution was extracted three fold with $100 \mathrm{ml}$ of hexane; the pooled hexane fractions were evaporated and dissolved in $1 \mathrm{ml}$ of hexane. Quantitative analysis 
of phylloquinone in food extracts was performed by HPLC with postcolumn reduction and fluorescence detection, according to the same procedure as described for serum. All measurements were made in duplicate, and mean values are used throughout this paper.

\section{RESULTS}

Before starting the experiment, the various sources of vitamin $K$ were checked for their phylloquinone content. The deep-frozen spinach used in the study was found to contain $4.41 \mu \mathrm{g}$ of phylloquinone per gram (wet weight), so that 227 grams of spinach are equivalent to $1 \mathrm{mg}$ of phylloquinone. Butter contained $60 \mathrm{ng}$ of phylloquinone per gram; hence the contribution of phylloquinone in the $25 \mathrm{~g}$ of butter (week 2) to serum vitamin $\mathrm{K}$ levels will be regarded as negligible. Finally also the phylloquinone content of Konakion was checked, and found to be $20.0 \mathrm{mg} / \mathrm{ml}$.

Vitamin $\mathrm{K}$ was administered to the participants as a single oral dose, and in all cases circulating phylloquinone levels had returned to their starting levels after $24 \mathrm{~h}$. Nevertheless a wash-out period of 6 days was scheduled between the three

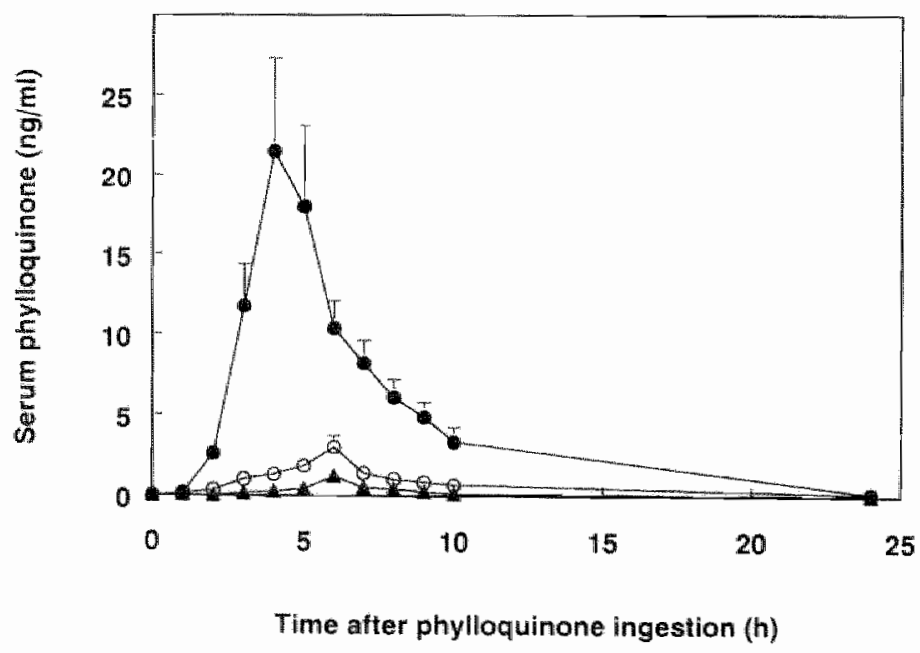

Figure 1. Intestinal absorption of vitawin $K$ from differem sources. One mg of phylloquinone was given as a single, oral dose to five fasting volunteers. Sources of phylloquinone were either Konakion (-), spinach + butter $(0)$ or spinach without additives (4). The data at each time point are given as the neans of the five individual values \pm SE. Further derails are given is the text. 
Table 1:

Effect of wamin $K$ from different sources on serwm phyloqumone lewe

\begin{tabular}{lcccccc}
\hline Subject & \multicolumn{2}{l}{ Konakion } & \multicolumn{2}{c}{ Spinach + butier } & \multicolumn{2}{c}{ Spinach - buttar } \\
& AUC & AUC & $(\%)$ & AUC & $(\%)$ \\
\hline A & 139.7 & 100 & 18.3 & 13.1 & 2.6 & 1.9 \\
B & 97.0 & 100 & 11.9 & 12.3 & 4.4 & 4.6 \\
C & 90.4 & 100 & 7.9 & 8.8 & 3.1 & 3.4 \\
D & 54.8 & 100 & 11.5 & 21.0 & 6.0 & 10.9 \\
E & 52.5 & 100 & 8.2 & 15.6 & 1.9 & 3.7 \\
& & & & & & \\
Mean & 86.9 & 100 & 11.6 & 13.3 & 3.6 & 1.4 \\
\hline
\end{tabular}

The letters $A$ through $\mathbb{E}$ represent the five participants in the sudy. AUC stands for the area under each individual absorption curve, the AUC values for both spinach regimens are expressed as a percentage of the corresponding Konakion experiment.

experimental days. During each of the experimental days one meal (noon) with low fat and vitamin $\mathrm{K}$ content was allowed. It is assumed that vitamin $\mathbb{K}$ absorption was not influenced by this meal. For each participant the serum phylloquinone concentration was established with 1 h intervals, and the mean values ( $\pm \mathrm{SE})$ are given in Figure 1. It is striking that very similar curves were obtained for all subjects: peak values were at $4 \mathrm{~h}$ (Konakion) and $6 \mathrm{~h}$ (spinach) after vitamin $\mathrm{K}$ ingestion, with only some interindividual variations in the peak heights. The absorption of phylloquinone from vegetables was slower than that from Konakion ${ }^{\circledR}$ by a factor 1.5. Butter had only an effect on the peak height, not on the time at which the maximal serum concentration was reached.

The total amounts of phylloquinone absorbed were calculated for each participant from the Area Under Curve (AUC) between 0 and 10 h after the start of the vitamin $\mathbb{K}$ ingestion, and the data obtained for spinach (both in the presence and absence of butter) were expressed as a percentage of the data for Konakion*. As can be seen in table I, the mean absorption of phylloquinone from spinach alone is $4 \%$ from that of Konakion, whereas the effect of simultaneous consumption of butter improves this figure with no more than a factor 3 . At $24 \mathrm{~h}$ after vitamin $\mathrm{K}$ ingestion the serum phylloquinone levels had decreased to the starting levels, irrespective of the peak height the day before. This shows that nutritional effects 
are nihilated after an overnight fast, which is consistent with the short half-life time of vitamin $K$ in the circulation $(2 \mathrm{~h})$.

\section{DISCUSSION}

From the data presented in this paper it is clear that phylloquinone is readily absorbed from Konakion, with a peak time of $4 \mathrm{~h}$. This is in accordance with previous observations of Shearer, who found a peak time between 2 and $4 \mathrm{~h} .^{17}$ The later peak time for phylloquinone from spinach indicates that its absorption from plant cells is a more time-consuming process, which may be infuenced by digestive factors, such as the rate at which phylloquinone is extracted from the cellular membranes. The concomitant intake of fat may increase the phylloquinone peak height, but obviously does not influence the rate of absorption. The effect of fat is probably due to its stimulation of bile secretion, which is known to be important for the absorption of hydrophobic compounds. ${ }^{17}$

Our data also indicates that the mean intestinal absorption of dietary phylloquinone is only a small fraction of the total phylloquinone content which may be extracted from the food using organic solvents. As was reported earlier, the efficiency of intestinal absorption of phylloquinone from Konakion is about $80 \% .{ }^{17}$ Based on this figure it may be calculated from our data that less than $10 \%$ of phylloquinone present in green vegetables is absorbed in the digestive tract. Furthermore it should be taken into account that data from our lab and elsewhere indicate that the colonic absotption of menaquinones produced by the intestinal flora is extremely poor. ${ }^{10.13 .12}$ It may be concluded, therefore, that the relative effect of nutritional menaquinones is probably higher than generally assumed. More information about food contents and bioavailability of nutritional menaquinones is needed, however, to substantiate this conclusion. Our data demonstrate that the bioavailability of phylloquinone is substantially less than assumed up until now, and that the fat content of the meal is an important determinant for pliylloquinone absorption.

\section{REFERENCES}

1. Suthe JW. Vitamin K-dependent carboxylase. Ann Rev Biochem 1985;54:459-77.

2. Vermeer $\mathrm{C}$. $\gamma$-Caboxyglutamare-containing protems and the vitamin $\mathrm{K}$-dependent carboxylase. Biochem J 1990:266:625-36.

3. Furie B, Furie BC. Molecular and cellular biology of blood congulation. New Engl I Med $1992 ; 326: 800-6$. 
4. Hauschka PV. Lian JB. Cole DEC. Gundberg CM. Osteocalcin and Matrix Gla Protein: vitamin K-dependent proteins in bone. Phys Rev 1989:69:990-1047.

5. Manfioletti $G$, Brancolini $C$, Avanzi $G$, Schneider $C$. The protein encoded by at growilh arrestspecific gene (gas 6 ) is a member of the vitamin $K$-dependent proteins related to protem $S$, a negarive coregulator in the blood coagulation cascade. Moll Cell Biol 1993:13:4976-85.

6. Booth SL, Sadowski JA, Weihrauch JL, Ferland G. Vitamin $K_{1}$ (phylloquinone) content of foods: a provisional table. J Food Composition Analysis 1993;6:109-20.

7. Hirauchi K, Sakano T. Notsumoto S, Nagaoka T, Morimoto A. Fujimoto K. Matsuda S, Suzuki $Y$. Measurement of $\mathrm{K}$ vitamins in foods by high-performance liquid chromatography with fluorometric detection. Vitamins (Japan) 1989;63:147-51

8. Sakano T, Notsumoto S, Nagaoka T, Morimoto A. Fujimoto K. Matsuda S. Suzuki Y, Hirauchi $K$. Measurement of $\mathbb{K}$ vitamins in foods by high-performance liquid chromatography with fluorometric detection. Vitamins (Japan) 1989;62:393-8.

9. Conly $\mathbb{M}$, Stein $K$. The production of menaquinones (vitamin $K 2$ ) by intestinal bacteria and their role in maintaining coagulation homeostasis. Progr Food Nutr Science 1992;16:307-43.

10. Lipsky JJ. Antibiotic-associated hypoprothrombinamia. J Antimicr Chemother 1988:21:281-300.

11. Lipsky JI. Nutritjonal sources of vitamin K. Mayo Clin Proc 1994;69:462-466.

12. Groenen-van Dooren MCL, Soute BAM, Jie K-SG, Thijssen HHW, Vermeer C. The relative effects of phylloquinone and menaquinone on the blood coagulation factor symthesis in vitamine K-deficient rats. Biochem Pharmacol 1993;46:433-7.

13. Shearer MJ, von Kries R, Saupe J. Comparative aspects of human vitamm $\mathrm{K}$ unetabolism and nutriture. J Nutr Sci Vit 1992; S 13-3:413-6.

1.4. Lichtenthaler HK. The plant prenyllipids, including carotenoids, chlorophylls and prenylquinones. In: Moore T, editor. Plant Lipids. Boca Raton, USA: CRC Press Jnc, 1993:42 I-64.

15. Hart JP, Shearer MJ, Klenerman L. Catteral A, Reeve J, Sambrook PN, Dodds RA, Bitensky L. Chayen J. Electrochemical detection of depressed circulating levels of vitamin KI in osteoporosis. J Clin Endocrin Metab 1985;60:1268-9.

16. Thijssen HHW, Dritty-Reinders MJ. Vitamin K metabolism and vitannin $\mathrm{K} I$ status in human liver samples: a search for inter-individual differences in warfarin sensitivity. Brit I Hatem 1993;84:681-5.

17. Shearer MJ, McBurney A. Barkhan P. studies on the absorption and metabolism of phylloquinone (vitamin $K_{1}$ ) in mant. Vitamins and Hormones 1974:32:513-42. 



\title{
A POPULATION-BASED STUDY IN WOMEN WITH OR WITHOUT ATHEROSCLEROSIS:
}

\author{
6.1 VITAMIN K INTAKE AND OSTEOCALCIN LEVELS
}

6.2 VITAMIN K STATUS AND BONE MASS 



\title{
A POPULATION-BASED STUDY IN WOMEN WITH OR WITHOUT ATHEROSCLEROSIS: VITAMIN K INTAKE AND OSTEOCALCIN LEVELS
}

\author{
Kon-Siong G. Jie', Michiel L. Bots ${ }^{2}$, Cees Vermeer ${ }^{1}$, Jacqueline C.M. \\ Witteman ${ }^{2}$, Diederick E. Grobbee ${ }^{2}$ \\ Department of Biochemistry and Cardiovascular Research Institute Maastrich, University of \\ Limburg, Maastricht, The Netherlands \\ 2. Deparment of Epidemiology \& Biostatistics, and Cardiowascular Research Institute Rotterdam \\ (COEUR), Erasmus University Medical School, Rotterdam, The Netherlands
}

\section{SUMMARY}

Protein-bound $\gamma$-carboxyglutamate (Gla) has been demonstrated in calcified atherosclerotic plaques. Vitamin $\mathbb{K}$ is required for the formation of Gla-residues in proteins. As the biological activity of Gla-proteins appears to be strictly dependent on the presence of the Gla-residues, vitamin K status may be an important factor in the development and progression of atherosclerotic calcifications. We studied the association of vitamin $\mathrm{K}$ status as assessed by nutritional vitamin $\mathrm{K}$ intake and measurements of two circulating immunoreactive osteocalcin (irOC) fractions, with aortic atherosclerosis in a population-based study of 113 postmenopausal women. Women with calcified lesions $(n=34)$ had a $42.9 \mu \mathrm{g}$ lower mean age-adjusted dietary intake of vitamin $\mathrm{K} /$ day $[95 \% \mathrm{Cl}-6.6$ to 92.5$]$ than those without calcifications $(n=79)$. Atherosclerotic women had higher irOC levels with a low affinity for hydroxyapatite (irOC ${ }_{\text {free }}$ ): age-adjusted difference of $0.32 \mathrm{ng} / \mathrm{ml} 195 \% \mathrm{Cl} 0.03$ to $0.61 \mathrm{I}$. In addition, the high affinity irOC levels expressed as a percentage (hydroxyapatite binding capacity, HBC) were $5.12 \%$ (95\% Cl 1.32 to 8.921 ) lower in women witl calcifications. Our study indicates that women with aortic atherosclerosis have a reduced vitamin $\mathrm{K}$ status as reflected by a lower nutritional vitamin $\mathrm{K}$ intake, an increased irOC $_{\text {free }}$ level and a reduced HBC level. An impaired vitamin $\mathrm{K}$ status in subjects with atherosclerosis is compatible with the view that vitamin $\mathrm{K}$ or Gla-containing proteins are involved in the development of calcifications of the vessel wall. 


\section{INTRODUCTION}

Cardiovascular disease is caused by an interplay between thrombosis and advanced atherosclerotic vessel wall changes. ${ }^{1}$ The development of atherosclerotic lesions is a slow process in which gradual thickening of the vessel wall occurs, and localized atherosclerotic plaques may arise. ${ }^{2}$ Plaques may further develop into non-calcified and calcified lesions. Recently proteins containing the aminoacid $\gamma$-carboxyglutamate (Gla), such as osteocalcin and plaque Gla protein (PGP), have been demonstrated in calcified atherosclerotic plaques and in calcified aortic valves, ${ }^{3,4.5,6.7}$ whereas in normal arterial wall and in non-mineralized lesions Gla-proteins are found only at trace levels. ${ }^{8.9}$ The presence of Gla is strongly associated with the amount of calcium in these calcified lesions, suggesting an involvement of Gla-proteins in vascular $\mathrm{Ca}^{+4}$-deposition. ${ }^{4}$ Recent studies have indicated that both osteocalcin and matrix Gla protein (MGP) may play a role in the atherosclerotic calcification process. ${ }^{10,1}$ Vitamin $K$ is required for the carboxylation of certain protein bound glutamate residues into the strongly negatively charged aminoacid Gla. ${ }^{12.13 .14}$ As the biological activity of Gla-proteins appears to be strictly dependent on the presence of the Gla-residues, ${ }^{13.14}$ vitamin $\mathrm{K}$ status may be an important factor in the development and progression of atherosclerotic calcifications.

The assessment of vitamin $\mathrm{K}$ status has generally been based on coagulation tests. These tests, however, have a maximum sensitivity only during a severe deficiency state. ${ }^{14}$ Recently, we have shown that even in mild levels of vitamin $\mathrm{K}$ deficiency, the Gla-content of serum osteocalcin levels reflects the vitamin $\mathrm{K}$ status. ${ }^{15,16,17,18}$ Therefore, we regard the circulating osteocalcin Gla-content as the most sensitive marker available for measuring the current vitamin $\mathrm{K}$-status. Atherosclerosis is the result of long-lasting pathophysiological processes probably due to unfavorable conditions during many years. In the present study we have investigated whether a long term low vitamin $\mathrm{K}$ intake as estimated by a food frequency questionnaire is associated with aortic atherosclerosis. Subsequently the current vitamin $\mathrm{K}$ status as indicated by the serum osteocalcin Gla-content was related to the presence of atherosclerotic calcifications in a population-based study among postmenopausal women. 


\section{METHODS}

\section{Subjects}

In 1985,855 women, aged $55-75$, participated in a population-based study on determinants of osteoporosis and atherosclerosis. All subjects were examined radiographically for calcified deposits in the abdominal aorta. ${ }^{19}$ These calcified deposits have been shown to represent intimal atherosclerosis ${ }^{20.21}$ and have been associated with cardiovascular disease at several sites ${ }^{22.23}$ and with cardiovascular mortality. ${ }^{24,25}$ In 1990,300 of the 855 randomly selected women were invited to take part in our study, of whom $256(85.3 \%)$ consented to participate. Subjects using vitamin $\mathrm{K}$ antagonists were excluded. Advanced aortic calcifications were present in 34 subjects. Measurements of the vitamin $\mathrm{K}$ status were performed in this group as well as in 79 women randomly selected from the cohort of women without aortic calcifications.

\section{MEASUREMENTS}

\section{Abdominal aorta}

Atherosclerosis of the abdominal aorta was assessed using a lateral $\mathrm{X}$-ray of the lumbar spine (T12-S1), on which the presence of calcified deposits was determined. Calcifications were considered to be present when linear densities were clearly visible in an area parallel and anterior to the lumbar spine (L1-L4) ${ }^{19}$ All films were examined by two independent observers without knowledge of the risk factor status of the subjects. The severity of the atherosclerosis was graded according to the length of the involved area $(\leq 1 \mathrm{~cm}, 2-5 \mathrm{~cm}, 6-10 \mathrm{~cm},>10 \mathrm{~cm})$. The third and fourth classses were combined as advanced aortic atherosclerosis, whereas the first class was considered as no aortic atherosclerosis. ${ }^{21}$

\section{Dietary vitamin $K$ intake}

The daily vitamin $\mathrm{K}$ intake was determined using a food frequency questionnaire, with emphasis on food products with a high known vitamin $\mathrm{K}$ content such as vegetables, dairy products. The calculation of vitamin $\mathbb{K}$ content of various food items was based on data kindly provided by Dr. M.I. Shearer (Haemophilia Centre, St Thomas Hospital, London) corresponding to published values. ${ }^{26,27}$ The average vitamin $\mathbb{K}$ content of each food item was multiplied by the amount and frequency of the reported use of the food item. The data thus obtained were summarized and used as an estimate of the indiviclual daily vitamin $\mathrm{K}$ intake. 


\section{Anthropometric variables}

Height and weight were measured without shoes and with indoor clothing. Body mass index $\left(\mathrm{kg} / \mathrm{m}^{2}\right)$ was calculated. The circumference of the waist and hip were measured and the waist-to-hip ratio was calculated.

\section{Vitamin $K$ status}

Non-fasting blood samples were collected by venipuncture. For the preparation of serum, blood samples were left at room temperature for 1 hour, briefly centrifuged, and immediately frozen at $-80^{\circ} \mathrm{C}$. Serum immunoreactive osteocalcin (irOC) levels were measured by radioimmunoassay (Incstar, Stillwater, $\mathrm{MI}$ ) before (irOC ${ }_{\text {total }}$ ) and after (irOC $\mathrm{Cret}_{\text {fret }}$ ) extraction with $100 \mathrm{mg} / \mathrm{ml}$ hydroxyapatite. ${ }^{18}$ IrOC $_{\text {boumul }}$ was calculated from the difference between $\operatorname{irOC}_{\text {toral }}$ and irOC $\mathrm{C}_{\text {iree }}$. The hydroxyapatite binding capacity (HBC) was calculated as the percentage of irOC $\mathrm{Coum}_{\text {belative to the }}$ irOC $\mathrm{C}_{\text {toal }}$ level, based on the Gla-dependent affinity of osteocalcin for hydroxyapatite. ${ }^{18.28}$ By measuring irOC before and after extraction of serum with hydroxyapatite, two fractions of serum irOC (differing in Glacontent) may be distinguished: irOC with low (irOC $\mathrm{fret}_{\text {f }}$ ) or that with high (irOC $\mathrm{C}_{\text {hound }}$ ) affinity for hydroxyapatite. ${ }^{29}$ The inter- and intra-assay coefficients of variation of $\mathrm{irOC}_{\text {total }}$ were $10 \%$ and $5 \%$, respectively. In the present study irOC $_{\text {free }}$ and the HBC levels were used as overall estimates of the Gla-content of circulating irOC levels.

\section{Data analysis}

Mean levels of vitamin $\mathrm{K}$ intake and osteocalcin fractions were compared between subjects with and without atherosclerotic calcifications in the abdominal aorta using Student t-tests. Multiple linear regression was used for analysis of differences across groups adjusted for variables such as age and anthropometric variables. The differences are presented with a $95 \%$ confidence interval (CI). Analyses were performed using BMDP statistical package.

\section{RESULTS}

General characteristics of women with and without calcifications of the abdominal aorta are presented in Table 1.

\section{Vitamin $K$ intake}

The mean age-adjusted vitamin $\mathrm{K}$ intake was lower among subjects with atherosclerosis of the abdominal aorta than among those without atherosclerosis, with a 
Table 1: Gesteral characteristics of the sudy population

\begin{tabular}{|c|c|c|c|c|}
\hline & \multirow{2}{*}{$\begin{array}{l}\text { Total } \\
\text { population }\end{array}$} & \multicolumn{3}{|c|}{ Aortic Calcifications } \\
\hline & & Absent & Present & P-value \\
\hline Number & 113 & 79 & 34 & \\
\hline Age (years) & $66.6(4.6)$ & $66.1[0.46]$ & $67.8[1.0]$ & 0.07 \\
\hline Body mass index $(\mathrm{kg} / \mathrm{m} 2)$ & $26.1(3.1)$ & $26.5[0.34]$ & $25.4[0.55]$ & 0.07 \\
\hline Waist-to-hip ratio & $0.84(0.06)$ & $0.84[0.007]$ & $0.84[10.009 \rrbracket$ & 0.81 \\
\hline
\end{tabular}

P-value refers to differences between groups with and wihout aortic calcifications. Values are expressed as means with standard deviations in parenthesis, and standard arrors in brackets.

Table 2.

Indicators of vitamin $K$ in postmenopausal women with and withort abdominal calcificarions

\begin{tabular}{|c|c|c|c|c|}
\hline & \multicolumn{2}{|c|}{ Aortic calcifications } & \multirow[t]{2}{*}{ Mean difference } & \multirow[t]{2}{*}{ Age adj. difference } \\
\hline & Absent & Present & & \\
\hline Number & 79 & 34 & & \\
\hline Vit $\mathrm{K}$ infake $(\mu \mathrm{g} / \mathrm{d})$ & $243.6(15.32)$ & $189.9(15.1)$ & $-53.7[-103.6,-3.8]$ & $-42.9[-92.5,6.6]$ \\
\hline $\operatorname{irOCt}(\mathrm{ng} / \mathrm{ml})$ & $4.70(0.15)$ & $4.70(0.28)$ & $0.01[-0.56,0.57]$ & $0.19[0.34,0.73$ \\
\hline irOCfree $(\mathrm{ng} / \mathrm{ml})$ & $1.93(0.08)$ & $2.16(0.15)$ & $0.23[-0.07,0.53]$ & $0.32[0.03,0.61]$ \\
\hline irOCbound $(\mathrm{ng} / \mathrm{ml})$ & $2.77(0.09)$ & $2.55(0.17)$ & $-0.22[-0.57,0.12]$ & $-0.13[0.46,0.21]$ \\
\hline $\mathrm{HBC}(\%)$ & $59.4(0.98)$ & $54.6(1.77)$ & $4.79 \mid-8.49 \cdot-1.099$ & $-5.12|-8.92,-1.32|$ \\
\hline
\end{tabular}

Values: means (standard errors) or $195 \%$ Confidence [ntervals]. Abbreviations: iroC $=$ total immunoreactive osteocalcin; irOCfree $=$ osteocalcin free; irOCbound $=$ osteocalcin bound $\mathrm{HBC}=$ Hydroxyapatite Binding Capacity of osteocalcin

difference of $42.9 \mu \mathrm{g} /$ day $[95 \% \mathrm{Cr}-6.6,92.5]$ (Table 2). Adjustment for differences in age, body mass index and waist-to-hip-ratio did not substantially alter the findings. The vitamin $\mathrm{K}$ intake according to age and presence or absence of aortic calcifications is shown in Figure 1. Vitamin $\mathrm{K}$ intake decreased considerably with increasing age with an average of $7.32 \mathrm{ug} /$ day per year of day $195 \% \mathrm{Cl}$ $4.08,10.60]$. While it was higher in the relatively younger women without calcifi 


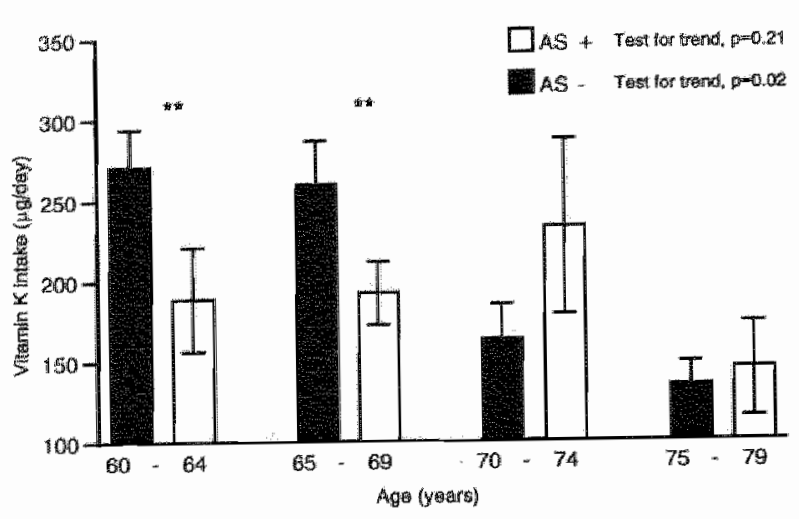

Figure 1. Mean witamin $K$ intake (SE) in postmenopausal women according to age and presence or absence of artic calcifications. AS = without aortic calcifications; $A S+=$ with aomic calcifications. Comparison betwen subjects with and without aortic atherosclerosis $(p<0.1)$.

cations, the decrease of vitamin $\mathrm{K}$ intake with age was present mainly in those without atherosclerotic calcifications of the abdominal aorta compared with subjects with aortic atherosclerosis: mean decrease of $10.08 \mathrm{ug} /$ day per year $[95 \%$ $\mathrm{Cl} 9.49,10.67]$ and mean decrease of 1.23 ug/day per year $[95 \% \mathrm{CI}$ $4.69,7,15$ ], respectively (Figure 1). In the atherosclerotic subjects the vitamin $\mathrm{K}$ intake was low in all groups; the relatively high value for the $70-74$ age-group was caused by one extreme outlyer. From Figure 1 it is clear that the difference in vitamin $\mathrm{K}$ intake between atherosclerotic and non-atherosclerotic subjects (as given in Table 1) are mainly due to the nutritional habits in the 60-69 age group. In this group the difference in vitamin $\mathrm{K}$ intake was $-75.4 \mu \mathrm{g} /$ day $195 \% \mathrm{Cl}$. $135.4,-15.5 \mathrm{~J}$, whereas in the $70-79$ age group the difference was not significant. After adjustment for age the difference was $-74.8[95 \% \mathrm{Cl}-135.1,-14.6]$.

\section{Serum osteocalcin fractions}

The mean age-adjusted irOC frec level among women with aortic atherosclerosis was higher than in those without aortic lesions with a difference of $0.32 \mathrm{ng} / \mathrm{ml}$ $195 \% \mathrm{Cl} 0.03,0.61]$ (Table 2). Women with aortic atherosclerosis had significantly lower mean age-adjusted HBC levels with a difference of $5.12 \%$ [95\% Cl $1.32,8.92]$. When differences in body mass index and waist-to-hip ratio were taken into account, the associations remained of similar direction, magnitude and significance. Both irOC fractions were significantly and negatively associated with age, body mass index and waist-to-hip ratio (data not shown). A weak non- 
significant association was found between dietary vitamin $\mathrm{K}$ intake and irOC $_{\text {fite }}$ level (beta-7.0, se 16.0)) and HBC level (beta 0.59, se 1.23).

\section{DISCUSSION}

The findings in the present study suggest that vitamin $\mathrm{K}$ status as measured by vitamin $\mathrm{K}$ intake, irOC $\mathrm{C}_{\text {rree }}$, and $\mathrm{HBC}$ levels is reduced in older women with aortic atherosclerosis.

Before these results can be accepted, some aspects of this study need to be discussed. Firstly, the validity of roentgenographic assessment of aortic calcification in the diagnosis of advanced atherosclerosis has been studied by comparison with assessments made on necropsy material, ${ }^{20}$ and the method was shown to be highly specific. In a recent comparison of radiographs and $\mathrm{CT}$ images of calcified aortas the calcifications were shown to be within the vascular wall of the aorta. ${ }^{21}$ Roentgenographically assessed aortic calcifications have been shown to be associated with cardiovascular risk factors ${ }^{19,30,31}$ and their presence has been found to be a predictor of coronary heart disease 22,32 and cardiovascular mortality. 22,24,25 Moreover, the presence of callcification in the abdominal aorta has been associated with atherosclerosis in other arterial vessels. ${ }^{33}$

Secondly, the extent to which the 5 year interval between the assessment of atheroscleroses of the abdominal aorta and the measurement of the vitamin $\mathrm{K}$ status may have affected our results should be addressed. Based on earlier findings it is not likely that the calcified atherosclerosis of the abdominal aorta present at baseline would regress over a five year period." However, some women initially without atherosclerosis of the abdominal aorta may have developed aortic atherosclerosis during these 5 years. Assuming that a true association exists between vitamin $\mathbb{K}$ status and aortic atherosclerosis, this misclassification of atherosclerotic status, if present, will have attenuated the observed association. Thus, the true association may actually be stronger than observed.

The vitamin $\mathrm{K}$ intake in the present study is in accordance with the limited data reported by others, in which vitamin $\mathrm{K}$ intake varies from 50 to $500 \mu \mathrm{g} / \mathrm{day}$ depending on the characteristics of the population studied. ${ }^{34.35 .36}$ Plasma viw tamin $\mathrm{K}$ levels have been shown to be strongly influenced by recent vilamin $\mathrm{K}$ intake. ${ }^{14.34}$ Our finding of a decrease in vitamin $K$ intake with age may suggest that a lower dietary vitamin $\mathrm{K}$ intake is one of the factors accounting for the observed lower plasma vitamin $\mathrm{K}$ levels in elderly. ${ }^{34}$ This is of particular interest because our findings indicate that women without aortic calcifications appear to initially have a higher vitamin $\mathrm{K}$ intake which gradually decreases and only after 
the age of 75 years reaches the lower vitamin $K$ intake level of women with aortic atherosclerosis. Since the differences were mainly found in the younger age-groups, it would by worthwhile to also investigate the nutritional vitamin $\mathrm{K}$ intake among atherosclerotic and non-atherosclerotic subjects aged 40-60 years.

For measuring vitamin $\mathrm{K}$ status at the time of the study we have not chosen circulating phylloquinone because vitamin $K$ status is determined not only by phylloquinone, but also by menaquinones, the detection of which still raises serious problems. The main reason, however, is that the relation between circulating vitamin $\mathrm{K}$ concentrations and tissue vitamin $\mathrm{K}$ status is only poorly understood. Results from several studies support the view that the Gla-content of extrahepatic proteins may be regarded as a sensitive indicator for the vitamin $\mathrm{K}$ status. $15,16.67,18,37,38$ Recently we have successfully used the HBC of osteocalcin for this purpose. The $\mathrm{HBC}$-values reported here are in line with previous findings, indicating that a poor vitamin $\mathrm{K}$ status is common among elderly women. ${ }^{1829}$ The lower HBC levels in the atherosclerotic women are consistent with their lower vitamin $K$ intake. Only a weak non-significant association was found between the dietary vitamin $\mathrm{K}$ intake and the HBC levels. This finding is consistent with the view that apart from vitamin $\mathrm{K}$ intake other factors such as the absorption or transport of vitamin $\mathrm{K}$ to the tissue, plasma triglyceride and lipoprotein content, may be important as determinants of vitamin $\mathrm{K}$ status. Hence substantial interindividual variations may exist in the efficiency of vitamin $K$

Osteocalcin is probably directly involved in the vascular mineralization process. ${ }^{3.4,7}$ Recently, it has been shown that osteocalcin is present in the atherosclerotic plaque, ${ }^{7}$ and that both osteocalcin and MGP can be produced locally in the atherosclerotic plaque and may directly be involved in calcification."11"I Osteocalcin may effectively inhibit the precipitation of calcium phosphate and hydroxyapatite crystal growth. ${ }^{39}$ The exact function of the various Gla proteins in the arherosclerotic plaque, however, remains to be elucidated. Higher levels of iroC $\mathrm{C}_{\text {pete }}$ in the atherosclerotic women than in women without aortic calcification may suggest elevated circulating levels of Gla deficient osteocalcin. ${ }^{18,28,29,38}$ Assuming that these Gla-deficient osteocalcin molecules are hampered in their function, i.e. the inhibition of calcium salt precipitation, the calcification process in the vessel wall may take place at an increased rate.

In conclusion, our study indicates that atherosclerotic women have an impaired vitamin $\mathrm{K}$ status as reflected by a lower nutrutional vitamin $\mathrm{K}$ intake, an increased $i r O C_{\text {free }}$ and a lower $\mathrm{HBC}$ level. An impaired vitamin $\mathrm{K}$ status in subjects with atherosclerosis is compatible with the view that vitamin $\mathrm{K}$ or Glacontaining proteins are involved in the development of calcifications of the vessel 
wall. Further studies are needed to clarify the exact mechanisms involved and their potential implications for prevention and intervention.

\section{ACKNOWLEDGMENT}

The authors gratefully acknowledge the contribution of Mrs H. den Breeijen and Mrs $\mathrm{H}$. de Bruin in the collection of the data.

\section{REFERENCES}

1. Meade TW. Thrombosis and cardiovascular disease. Ann Epidentol 1992,2:353-64.

2. Fuster $V$, Badimon L, Badimon JJ, et al. The porcine model for understanding of duonbogenesis and aherogenesis. Mayo Clim Proc 1991:66:818-31.

3. Gallop PM, Lian JB, Hauschka PV. Carboxylated calcium-binding proteins and vitamin $K$. $N$ Eng J Med 1980:302: 1460-66.

4. Levy RI, Zenker J, Lian JB. Vitamin K-dependent calcium-binding protedns in aortic walve calcifications. J Clin Invest 1980;65:563-6.

5. Levy RJ, Howard SL, Oshry L. Carboxyglutamic acid (Gla) containg protelus of human calcified atherosclerotic plaque solubilized by EDTA. Atherosclerosis $1986 ; 59: 155-60$.

6. Gijsbers BMLG, wan Hartem IJM, Soute BAM, Ebberink RHM, Verneen C. Chatacterization of a Gla-containing protein from calcified human atherosclerotic plaques. Arteriosclerosis $1990 ; 10: 991-5$

7. Levy RJ, Gundberg $C$, Scheinman $\mathbb{R}$. The identification of the vitamin $K$-dependent bone protein osteocalcin as one of the $\gamma$-carboxyglutamic acid contaning proteins present in calcified atheroselerotic phaque and mineralized theart valwes. Atherosclerosis 1983,46,49-56.

8. Lian JB. Skminer M, Glimecher MJ, Gallop PM. The presence of yocarboxyglutamie acid in the protens associated with ectopic calcification. Biochem Btophys Res Comm 1976:73:349-55.

9. Levy R. Lian JB. Gallop PM. A therocalcin a youboxyglutamic acid containg protein from adheroscherotic plaque. Biochem Biophys Res Comm 1979:91:41-9

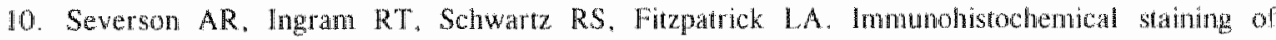
poreine vascular smooth muscle cells grown in vitro for bone sitoprotem, osteocalcin, osteopontin, osteonectin and procollagen type 1. Anatomical Record Suppl 1993:1:103.

11. Shanahan CM. Weissberg PL, Metcalfe IC. Isolation of gene natikers of differentiated and proliferating vascular smooth muscle cells. Circulation Research 1993;73:193-204.

12. Furie B, Furie BC Molecular basis of vitamin K-dependent $\gamma$-carboxylation. Blood $1990: 75: 1753-62$

13. Verneer C. y Carboxyglutamatecontaning proteins and the vitamin $\mathrm{k}$-dependent carboxylase Blochem J $1990,266: 625-36$.

14. Shearer MJ. Vilamin K metabolism and nutriture. Blood Reviews 1992:6:92 104.

15. Vermeer $\mathrm{C}$. Knapen MHJ, Jie K-SG. Grobbe DE. Physological mportance of extra-hepatic vitamin $\mathrm{K}$ dependent carboxylation reactions. Ann $\mathrm{NY}$ Acad Sci 1992;669:2 1-33.

16. Jie K-SG, Gijsers BLMG, Knapen MHJ, Hamuyák K. Frank HL, Verneer C. Effecks al

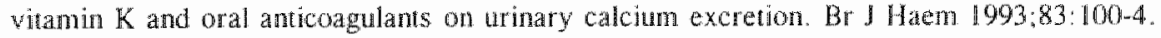


17. Jie K-SG, Hamulyâk K, Gijsbers BLMG, Roumen FJME, vermeer C. Serum osteocalcin as a marker for vitamin $K$-status in pregnant women and their mewborn baby's. Thromb Haemost $1992 ; 68: 388-91$.

18. Knapen MHJ. Hamulyk $K$. Vermetr $C$. The effect of vitamin $K$ supplementation on circulating osteocalcin (bone Gla-protein) and urinary calcium excretion. Ann Int Med 1989:111:100t-5.

19. Wilteman JCM, Grobbee DE, Vakenburg HA. Hemert AM van, Stijnen T, Hofman A. Cigaretle smoking and the development and progression of aortic atherosclerosis. A 9 -year population-based follow-up study in women. Circulation 1993,88:2156-62.

20. Hyman $\mathbb{B B}$, Epstein $\mathrm{FH}$. A study of the correlation between roentgenograplic and post-mortem calcification of the aorta. Am Hean J 1954;47:540-3.

21. Witteman JCM, Grobbee DE, Valkenburg HA, Hemert AM van, Sijnen T, Burger H, Hofman A. J-shaped relation beween change in diastolic blood pressure and progression of aoric atherosclerosis. Lancet 1994,343:504-07.

22. Witteman JCM, Kannel WB, Grobbee DE, et al. Aortic calcification plaques and cardiovascular dise ${ }^{2} s e$ (The Framingham Sudy). AM J Cardiol 1990,66:1060-4.

23. Sternby NH. Atherosclerosis in à defined population. An autopsy survey in Malmö. Sweden. Acta Pathol Microbiol Scand 1968;194(suppl):1-21.6.

24. Witteman JCM, KoK FJ, van Saase JLCM, Valkenburg HA. Aortic calcification as a predictor of cardiovascutar mortalicy. Lancet $1986 ; \mathrm{ii}: 1120-22$.

25. Eggen DA. Relationship of calcified lesions to clinically significant atherosclerotic lesions. Anm NY Acad Sci 1968:1419:752-67

26. Shearer MJ, Allan $V$, Haroon $Y$, Barkhan $P$. Nutritional aspects of vitanin $K$ in the human. In: Vitamin $K$ metabolism and vitamin $K$-dependent proteins. Surtie JW, editor. Baltimore: Univ. Park Press, 1980;317-27.

27. Booth SL, Sadowski JA. Weihrauch JL. Ferland G. Viramin $K_{1}$ (phylloquinone) content of foods: a provisional tabie. J Food Composition Analysis 1993;6:109-20.

28. Price PA, Williamson MK, Lothringer JW. Origin of the vitarmin K-dependent bone protein found in plasma and its clearance by kidney and bone. J Biol Chem $1981 ; 256: 12760-6$.

29. Knapen MHJ Jie K-SG. Hamulyák K, C.Vermeer. Vitamin $\mathrm{K}$ induced-changes in markers for osteoblast activity and urinary calcium loss. Calcif Tiss Int 1993:53:81-85.

30. Witreman ICM, Grobbee DE, KoK FJ, wan Saase JLCM, Valkenburg HA. Increased risk of atherosclerosis in women after the menopause. Br Med J 1989:298:642 4.

31. Niskanen LK, Suhonen M, Siitonen $O$, et al. Aortic and lower limb artery calcification in type 2 (non-insulin-dependent) diabetic patients and non-diabetic control subjects. Atheroselerosis $1990 ; 84: 61-71$.

32. Sitonen 0 . Uusitupa $M$, Pyorala $K$, et al. Aortic calcification and theur relationship to coronary heart disease and cardiowascular risk factors in patients with newly diagnosed non-insulin depend ent diaberes and in non-diabetic subjects. Cardiology 1987:74:335-9.

33. Bots ML. Wittenan JCM. Grobbee DE. Carotid intima-media thickness in elderly women with and without atherosclerosis of abdominal aorta. Aherosclerosis 1993;102:99-105.

34. Sadowski IA. Hood SI. Dallal GE, Garry PJ. Phylloquinone in plasma from elderly and young adults: factors influencing its concentration. Am J Clin Nutr 1989;50:100-8.

35. Olson JA. Recommended dietary intakes (RDI) of viramin $\mathrm{K}$ in humans. Am J Clin Nutr $1987 ; 45: 687-92$.

36. Suctie JW. Mummath-Schenkel LL, Shah DV, Lyle BJ, Greger JL. Vitamin K deficiency from dierary viamin $K$ restriction in humans. Am J Clin Nutr 1988:47:475 80.

37. Ferland $\mathrm{O}$. Sadowski IA. O'Brien ME. Dietary induced subclinical vitamin K deficiency in normal human subjects. J Clin Imest 1993;91:1761-68. 
38. Price PA. Vitamin $\mathrm{K}$ nutrition and postmenopausal osteoporosis [editorial]. I Clin Invest $1993 ; 91: 1269$.

39. van de Loo PGF, Soute BAM, van Harlem LJM, Vermeer C. The effect of Gla-contaning proteins on the precipitation of insoluble salts. Biochem Biophys Res Comm 1987:142:113-9. 



\section{A POPULATION-BASED STUDY IN WOMEN WITH AND WITHOUT ATHEROSCLEROSIS: VITAMIN K STATUS AND BONE MASS}

Kon-Siong G. Jie", Michiel L. Bots ${ }^{2}$, Cees Vermeer', Jacqueline C.M. Witteman², Diederick E. Grobbee ${ }^{2}$

- Department of Biochemistry and Cardiovascular Research Institute Maastuicht (CARIM), University of Limburg, Maastricht,

2 Deparment of Epidemiology \& Biostatistics, and Cardiovascular Research Institute Rotterdan (COEUR), Erasmus University Medical School, Roterdam, The Netherlands

\section{SUMMARY}

Gammacarboxyglutamate (Gla) is an uncommon amino acid formed by vitamin $\mathbb{K}$ action, giving vitamin K-dependent proteins calcium binding properties. Increasing evidence indicates that Gla-proteins are involved in the regulation of the calcification processes in both bone tissue and the atherosclerotic vessel wall. In a populationbased study we have previously shown that in a group of 113 postmenopausal women the presence of abdominal aortic calcifications is associated with a reduced vitamin $\mathrm{K}$ status. In this study we investigated whether this reduced vitamin $\mathrm{K}$ status was also associated with differences in bone mass or circulating callciotropic hormone levels. Women with atherosclerotic calcifications had an $8 \%$ lower bone mass (mean difference of $3.15 \mathrm{~mm}^{2}, 95 \% \mathrm{CI}: 0.18-6.72$ ). No differences between the two groups of women were observed for serum intact PTH (iPTH) and serum 25hydroxyvitamin $D$ levels. In the atherosclerotic women $(n=34)$ both markers for vitamin $\mathrm{K}$ status were associated with bone mass (irOC $\mathrm{C}_{\text {frex }}: r=-0.47, p=0.013$; $\mathrm{HBC}$ : $r=0.57, p=0.002$ ), whereas no such association was found in the non-atherosclerotic women $(\mathrm{n}=79)$. In addition iPTH levels were significantly associated with irOC $\mathrm{C}_{\text {fre }}$ $(r=0.30, p=0.002)$ and $\mathrm{HBC}(r=-0.27, p=0.005)$ in all the women tested. The atherosclerotic women in our study may be at higher risk for osteoporotic fractures

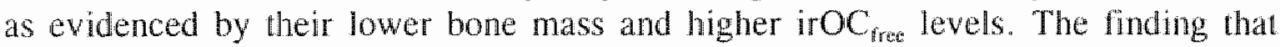
especially in atherosclerotic women vitamin $\mathrm{K}$ status is associated with bone mass, supports the view that vitamin $\mathrm{K}$ status affects the mineralization processes both in bone and in atherosclerotic plaques. 


\section{INTRODUCTION}

Osteoporosis and atherosclerosis are two major chronic causes of morbidity. Although they tend to be regarded as two independent, age-related processes, it is striking that in women the prevalence of both disorders increases dramatically after menopause.' Estrogen-deficiency or a derangement in Ca-metabolism have been proposed as candidates for common pathophysiological factors. ${ }^{2,3.4}$

Results from recent studies suggest that atherosclerotic calcification must be regarded as a highly regulated process similar to that occurring in bone tissue. ${ }^{5}$ It is of interest is that in both the calcification processes vitamin $\mathrm{K}$-dependent proteins are thought to be involved. ${ }^{6,789}$ Vitamin $\mathrm{K}$ dependent proteins have calcium-binding properties mediated by the posttranslationally acquired $\gamma$-carboxyglutamate (Gla) residues. ${ }^{10}$ A diminished availability of vitamin $\mathrm{K}$, e.g. due to a reduced nutritional intake or impaired intestinal absorption, may result in a decreased Gla-content of the various Gla-proteins. In the latter case Gla-proteins, such as osteocalcin will be functionally defective, resulting in a reduced affinity for the hydroxyapatite bone matrix. This can be measured in serum as the serum immunoreactive osteocalcin with a low affinity for hydroxyapatite (irOC $\mathrm{C}_{\text {free }}$ ). The high affinity osteocalcin (irOC $\mathrm{C}_{\text {bound }}$ ), expressed as a percentage of total serum osteocalcin, is called the hydroxyapatite binding capacity of osteocalcin (HBC) and is regarded as a measure for osteocalcin Gla-content and for vitamin $\mathrm{K}$ status. ${ }^{12}$

It has been suggested that even a mild vitamin K-deficiency may affect calcium homeostasis. In a number of trials, we have recently shown that markers of bone formation increase, while bone resorption markers decrease with the administration of pharmacological doses of vitamin $\mathrm{K}^{12.13 .14}$ These data are consistent with two Japanese studies, both of which demonstrated that vitamin $K$ supplementation may retard postmenopausal loss of bone mass. ${ }^{15.16}$ We have recently shown that in a group of postmenopausal women, the presence of atherosclerotic calcifications in the abdominal aorta, considered to be a strong predictor of cardiovascular heart disease and mortality, ${ }^{17,18,19}$ is associated with a marginal vitamin $\mathrm{K}$ status. ${ }^{20}$ In the present study we examined whether the reduced vitamin $\mathrm{K}$ status in the atherosclerotic women was associated with a reduced hone mass as well. 


\section{METHODS}

\section{Subjects}

Participants were selected from a population-based study on determinants of osteoporosis and atherosclerosis. ${ }^{21}$ Bone mass measurements as well as the extent of calcified deposits in the abdominal aorta were determined in 1985. In 1990,256 women consented to take part in a follow-up examination. ${ }^{20}$ In brief, aortic calcification (grade 3 or grade 4) was found to be present in 34 subjects. Seventy-nine women were randomly selected from the cohort without aortic calcification (grade 0). Subjects using vitamin $\mathrm{K}$ antagonists were excluded.

\section{Abdominal aorta}

Atherosclerosis of the abdominal aorta was assessed using a lateral X-ray of the lumbar spine (T12-S1), from which the presence of calcified deposits was determined. ${ }^{22}$ The severity of the atherosclerosis was graded from 0 (no calcifications) to 4 (aorta outlined with calcifications). ${ }^{20}$

\section{Bone mass}

Bone mass measurements was determined using Metacarpal Radiogrammetry. The outer diameter (D) and medullar diameter (d) were measured at the mid-shaft of the metacarpal bones, using a 7 times magnifying measurement loop with an accuracy of $0.01 \mathrm{~mm}$. Bone mass (metacarpal cortical area) was expressed as the mean value of $D^{2}-d^{2}\left(\mathrm{~mm}^{2}\right)$ of the metacarpal bones II, III, and IV of both hands. The mean intra-individual standard deviation of a duplicate measurement was 1.9 $\mathrm{mm}^{2}(4 \%)$.

\section{Anthropometric variables}

Height and weight were measured without shoes and with indoor clothing. The body mass index $\left(\mathrm{kg} / \mathrm{m}^{2}\right)(\mathrm{BMI})$ was calculated. The circumference of the waist and hip were measured and the waist-to-hip ratio (WH-ratio) was calculated.

\section{Vitamin $K$ status}

Immediately after preparation, the non-fasting serum and plasma samples were frozen at $-80^{\circ} \mathrm{C}$. Serum immunoreactive osteocalcin (irOC) levels were measured before (irOC $\mathrm{Cotal}_{\text {1 }}$ ) and after (irOC $\mathrm{rrex}_{\text {fre }}$ ) extraction with $100 \mathrm{mg} / \mathrm{ml}$ hydroxyapatite. ${ }^{12}$ IrOC $_{\text {pound }}$ was calculated from the difference between irOC $\mathrm{C}_{\text {tial }}$ and irOC $\mathrm{C}_{\text {free }}$. The Hydroxyapatite Binding Capacity ( $\mathrm{HBC}$ ) was calculated as the percentage of irOC $\mathrm{b}_{\text {bound }}$ relative to the total iroC level and used as an overall estimate of the Gla-content of circulating irOC levels. In young, healthy adults the $\mathrm{HBC}$ values 
range between 70 and $80 \%$, decreased values are found in subjects with a marginal vitamin $\mathrm{K}$-status. ${ }^{12.13}$ Inter-and intra-assay coefficients of variation of serum ${ }_{i r O C}$ were $10 \%$ and $5 \%$, respectively.

\section{Additional measurements}

Serum intact parathyroid hormone levels (iPTH) were measured with a direct immunoradiometric assay (IRMA) (N-tact ${ }^{\circledR}$ PTH SP) and serum 25-Hydroxyvitamin D (25OHD) levels were determined using a RIA (both obtained from Incstar, Stillwater, MI).

\section{Data analysis}

Multiple linear regression was used for analysis of differences across groups with and without atherosclerosis, adjusted for confounding variables such as age. The differences are presented with a $95 \%$ confidence interval $(95 \% \mathrm{CI})$. Analyses were performed using the BMDP statistical package. Results are presented as the mean values ( \pm standard deviation), unless indicated otherwise.

\section{RESULTS}

As reported previously, no major differences were noted between the women with or without atherosclerosis with respect to their age $(67.8$ (5.5) and 66.1 (4.1), respectively), BMI (25.4 (3.2) and $26.5(3.0) \mathrm{kg} / \mathrm{m}^{2}$, respectively) or WHratio $\left(0.84(0.05)\right.$ and $0.84(0.06)$, respectively).$^{20}$ The atherosclerotic women had higher total cholesterol levels $(7.56(1.05) \mathrm{mmol} / 1)$ compared to the non-atherosclerotic women $(6.85(1.00) \mathrm{mmol} / \mathrm{l}, \mathrm{p}<0.01)$, whereas no difference was noted in their HDL-cholesterol levels $(1.84(0.65)$ and $1.74(0.94) \mathrm{mmol} / \mathrm{l}$, respectively).

The bone mass of the atherosclerotic and non-atherosclerotic women was 41.6 and $45.1 \mathrm{~mm}^{2}$, respectively, constituting a mean difference of $3.44 \mathrm{~mm}^{2}$ $(95 \% \mathrm{Cl}:-6.72,-0.18)$ or $8 \%$ (Table). Adjustment for age slightly attenuated the difference to $-3.15 \mathrm{~mm}^{2}(95 \% \mathrm{Cl}:-6.47,0.17)$. In the atherosclerotic women bone mass was significantly associated with both irOC $\mathrm{C}_{\text {free }}(\mathrm{r}=-0.47, \mathrm{p}=0.013)$ and HBC levels $(r=0.57, p=0.002)$. No association was found in the women without atherosclerosis ( $\operatorname{irOC}_{\text {tree }}(r=0.12, p=0.33)$ or $\mathrm{HBC}(\mathrm{r}=-0.14, \mathrm{p}=0.28)$. Adjustment for age, BMI or cholesterol did not essentially alter these findings (data not shown).

No differences were observed in iPTH and 25OHD levels (table). 25OHD levels of $12 \mathrm{ng} / \mathrm{l}$ (considered as borderline value) and below were present in 44 
Table

Faraneters tested in postmenopasal women with and withou calcificanons of we abdominal aorka.

Aortic calcifications

Mean difference

Absent Present
Age adj difterence

\begin{tabular}{|c|c|c|c|c|c|c|}
\hline Number & 79 & 34 & & & & \\
\hline$\pi \mathrm{IOC}_{\text {ffec }}(\mathrm{ng} / \mathrm{ml})$ & $1.93(0.08)$ & $2.16(0.15)$ & 0.23 & {$[-0.07,0.53]$} & 0.32 & $\lceil 0.03,0.6\rceil$ \\
\hline $\mathrm{HBC}(\%)$ & $59.4(0.98)$ & $54.6(1.77)$ & -4.79 & {$[-8.49,-1.09]$} & -5.12 & $92,-1.32$ \\
\hline bone mass $\left(\mathrm{mm}^{2}\right)$ & $45.1(0.9)$ & $41.6(1.4)$ & -3.5 & {$[-6.7,-0.2]$} & -3.2 & {$[-6.5,0.2]$} \\
\hline $\mathrm{TH}(\mathrm{pg} / \mathrm{ml})$ & $41.6(1.8)$ & $43.7(2.8)$ & 2.1 & {$[-4.2,8.4]$} & 2.0 & {$[-4,4,8.5]$} \\
\hline $50 H D(\mathrm{ng} / \mathrm{ml})$ & $15.4(1.6)$ & $16.8(1.6)$ & 1.4 & {$[-3.1,5.8]$} & 1.8 & {$[-2.5,6.2]$} \\
\hline
\end{tabular}

Values: means (standard errors) or $[95 \%$ Confidence Intervals]. iroC $=$ serum immunoreactive osteocalcin; $\mathrm{HBC}=$ hydroxyapatite binding capacity; $\mathrm{iPTH}=$ intact serum PTH; 25OHD $=$ serum 25-Hydroxyvitamin D.

$\%$ of the women. ${ }^{23.24}$ In both groups, bone mass was positively associated with 25OHD levels (pooled data: $r=0.23, p=0.07$ ), but not with iPTH (pooled data: $r=0.10, p=0.36$ ). In the atherosclerotic women iPTH levels were negatively associated with HDL ( $r=-0.42, p=0.013)$. This association was most marked in those with 25OHD of $12 \mathrm{ng} / \mathrm{ml}$. or lower $(r=-0.73, \mathrm{p}=0.005)$ : a decrease of $0.1 \mathrm{mmol} / \mathrm{l} \mathrm{HDL}$ being associated with an increase in iPTH of $1.52 \mathrm{pg} / \mathrm{ml}$ (95\% CI: 0.68 to 2.36). iPTH levels were significantly associated with irOC free $_{\text {f }}$ (pooled data: $\mathrm{r}=0.30, \mathrm{p}=0.002$ ) and $\mathrm{HBC}$ (pooled data: $\mathbb{r}^{*}=-0.27, \mathrm{p}=0.005$ ) levels in both groups. The associations remained essentially unchanged after additional adjustments for possible confounders as age, BMI and serum cholesterol levels.

\section{DISCUSSION}

The results of our study indicate that in postmenopausal women the presence of atherosclerotic calcifications in the abdominal aorta is not only associated with a marginal vitamin $\mathrm{K}$-status, ${ }^{20}$ but also with a low bone mass. Atherosclerotic calcifications in the abdominal aorta have previously been shown to represent severe aortic atherosclerosis in comparisons with necropsy and CT findings. ${ }^{25.26}$ These calcifications have shown to be strong predictors of coronary 
heart disease ${ }^{27.28}$ and cardiovascular mortality. ${ }^{19.18 .27}$ Assessment of bone mass by radiogrammetry based on multiple measurements of six metacarpal bones, on the other hand, has been shown to be sufficiently precise for meaningful comparisons of bone density between individuals. ${ }^{21}$

A low bone mass is a well established and important risk factor for the development of osteoporotic fractures. ${ }^{29.30}$ Recent data strongly indicate that high irOC $_{\text {irec }}$ levels are associated with an increased risk for hip fractures ${ }^{31}$ and that in elderly women elevated $\mathrm{irOC}_{\mathrm{fie}}$ levels are associated with a low bone mass. ${ }^{32}$ The findings of our study that atheroselerotic women had a low bone mass and

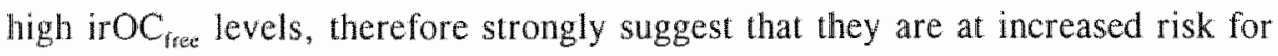
developing osteoporotic fractures.

Several studies have reported that both low bone mass and increased frequency of osteoporotic fractures are associated with atherosclerotic calcifications ${ }^{2,3,3,34,35,36}$ or cardiovascular deaths. ${ }^{4,37}$ Some have regarded the observed associations merely as being age related phenomena, ${ }^{34.35}$ wheras others have suggested a causal relationship. ${ }^{3.2 .33}$ High levels of iPTH or 25OHD have been proposed as causally related factors, however, this is not supported by our data. The 250HD and iPTH levels in our study are in accordance with other studies performed in The Netherlands. ${ }^{23,24}$ The relatively high iPTH levels in our study population are indicative of a secondary hyperparathyroidism commonly found in women of this age. ${ }^{24,38}$ The fact that $\mathrm{PTTH}$ is associated with irOC $\mathrm{C}_{\text {free }}$ levels, suggests that serum irOC $\mathrm{C}_{\text {tree }}$ may result from $\mathrm{PTH}$-mediated bone resorption. Although it is assumed that irOC free levels represent the undercarboxylated osteocalcin, there is some evidence that at least part of the circulating irOC $\mathrm{C}_{\text {free }}$ consists of osteocalcin degradation products, possibly originating from bone resorption. ${ }^{14.39}$ The strong association between PTH and HDL in the atherosclerotic women was unexpected. An explanation may be found in the observation that PTH is able to induce lipolysis, ${ }^{40}$ and that the increased free fatty acid release in serum leads to higher levels of (VLDL) triglyceride and subsequent lower HDL-cholesterol levels. ${ }^{41}$ This, however, requires further confirmation.

Evidence is accumulating indicating that vitamin $\mathrm{K}$ stimulates bone formation and inhibits bone resorption which ultimately may lead to a decrease in bone loss. ${ }^{2,13.14 .15 .16}$ The fact that only in the atherosclerotic women both markers for vitamin $\mathrm{K}$ status were strongly associated with bone mass suggests that additional (as yet unknown) factors may be of importance. It has been suggested for instance that abnormalities in lipoprotein metabolism may influence vitamin $\mathrm{K}$ transport to bone tissue. 
What may be the pathophysiological mechanism in which a reduced vitamin $\mathrm{K}$ status leads to a lower bone and an increased frequency of atherosclerotic calcifications? Recent evidence strongly supports the concept that the calcification associated with atherosclerosis must be regarded an active, highly organised process similar to that of osteogenesis..$^{542}$ Gla-proteins appear to be involved in both processes. ${ }^{6.89}$ The Gla-proteins MGP (matrix Gla-protein) and osteocalcin, are both involved in the bone mineralization process. Their exact function, however, is still unclear. It has been suggested that MGP may protect against excessive tissue calcification during early bone development. Recently, high levels of MGP mRNA and protein were demonstrated in macrophages and in vascular smooth muscle cells, present in human atherosclerotic plaques." This strongly suggests that MGP found in the plaques is not absorbed from the blood stream, but that it is produced locally at the site of these plaques. We speculate that the function of vascular MGP is similar to that in bone, i.e. that it acts as a mineralisation inhibitor. By analogy with the fetal warfarin syndrome, ${ }^{44}$ undercarboxylation of MGP would thus lead to an excessive minerallisation of the atherosclerotic vessel wall. Osteocalcin, on the other hand, is predominantly synthesized by the more differentiated osteoblast, relatively late in bone development, concomitant with or after the onset of mineralization..$^{45}$ Also its different molecular properties and tight association with the mineral matrix suggest a different function for osteocalcin, for instance in bone remodelling or in the accumulation of bone mass. ${ }^{46}$ In mature bone tissue, a suboptimal vitamin $\mathrm{K}$-status will therefore affect the osteocalcin-mediated remodelling process ultimately leading to a net loss of bone mass. ${ }^{12,13,14.15,16}$

In conclusion, we found that the presence of atherosclerotic calcifications in postmenopausal women is associated with an impaired vitamin $\mathrm{K}$-status as well as a low bone mass. These findings support the view that aortic calcification and bone loss may be two related processes, with vitamin $K$ deficiency as a common denominator. Further studies are needed to investigate the potential benefit of vitamin $\mathrm{K}$-supplementation.

\section{ACKNOWLEDGMENT}

The authors gratefully acknowledge the contribution of Mrs. H den Breeijen and Mrs $\mathrm{H}$. de Bruin in the collection of the data. 


\section{REFERENCES}

1. Stevengon JC. Osteoporosis and cardiovascular disease in women: converging path ? Lancet $1990 ; 336: 1121-2$.

2. Orimo H, Terashita K, Nakamura T, Ohshima J. Ca and atherosclerosis. J Nutr Sci Vitaminol 1985;31(Suppl): \$33-6.

3. Fujita $T$, Okamoto $Y$, Sakagami $Y$, Kjichiro 0 , Ohata $M$. Bone changes and aortic calcification in aging inhabiants of mountain versus seacoast communities in the Kii peninsula. I Am Soc Geriatric Soc 1984;32:124-8.

4. Browner WS, Seeley DG, Vogt TM, Cummings SR. Non-trauma mortality in elderly womer with low bone mineral density. Lancet 1991:338:355-8.

5. Demer LL, Watson KE, Bostroom $K$. Mechanism of calcification in atherosclerosis. Trends Cardiowase Med 1994;4:45-9.

6. Price PA, Otsuka AS, Poser JW, Kristaponis J, Raman N. Characterization of a $\gamma$-carboxyglutamic acid-containing protein from bone. Proc Natl Acad Sci USA 1976;73: 1447-51

7. Gallop PM, Lian JB. Hauschka PV. Carboxylated calcium-binding proteins and vitamin $\mathbb{K}$. N Eng I Med $1980 ; 302: 1460-66$.

8. Levy $\mathrm{RJ}$, Gundberg $\mathrm{C}$, Scheinnan $\mathrm{R}$. The identification of the vitarmin $\mathrm{K}$-dependent bone protein osteccalcin as one of the $\gamma$-carboxyglutamic acid containing proteins present in calcified atherosclerotic plaque and mineralized heart walves. Atherosclerosis 1983;46:49-56.

9. Shanahan CM, Cury NRB. Metcalfe JC. Weissberg PL. High expression of genes for calcification-regulating proteins in human atherosclerotic plaques. J Clin Invest 1994,93:2393 2402.

10. Vermeer $\mathrm{C}, \gamma$-Carboxyglutamate-containing proteins and the vitamin $\mathrm{K}$-dependent carboxylase. Biochem I 1990;266:625-36.

11. Price PA, Willamson MK, Lothringer JW. Origin of the vitamin K-dependent bone protein found in plasma and is clearance by kidney and bone. J Biol Chem 1981;256:12760-6.

12. Knapen MHI, Hamulyăk $\mathrm{K}$, Vermeer $\mathrm{C}$. The effect of vitamin $\mathrm{K}$ supplementation on circulating osteocalcin (bone Gla-protein) and urinary calcitum excretion. Ann Int Med 1989;111:10015 .

13. Jie K-SG, Gijbbers BLMG, Knapen MHJ, Hamulyák K, Frank HL. Vermeer C. Effects of vitamin K and oral anticoagulants on brinary calcium excretion. Brit J Haem 1993:83:100-4.

14. Kmapen MHJ, Jie K-SG, Hanulyák K. C.Vermeer. Vitamin K induced-changes in markers for osteoblast activicy and urinary calciun loss. Calcif Tiss Int 1993:53:81--5.

15. Akiba T, Kurihara $S$, Tachibana $K$, Kuwahara M, Sakamoto $H$, Yoneshima H, Marumo F. Vitamin $K(K)$ increased bone nass $(B M)$ in hemodialysis patients (Pts) with low turnover bone disease (L.TOBD). J Am Soc Nephrol 1991;2:608.

16. Orimo H. Shiraki M. Fujita T, Onomura T, Inoue T, Kushida K. Clinical evaluation of menaterenone in the treatment of involutional osteoporosis - a double-blind multicenter comparative study with l $\alpha$-hydroxy witamin $D_{3}$. I Bone Miner Res 1992; 7 Suppl 1.S122.

17. Witteman JCM, Grobbee DE, Kok FJ, van Saase JLCM, Valkenburg HA. Increased risk of atherosclerosis in women after the menopause. Br Med J 1989:298:642-4.

18. Wirteman ICM, Kok FJ, van Saase JLCM, Valkenburg HA. Aortic calcification as a predictor of cardiovascular mortily. Lancet 1986;ii:1120-22.

19. Eggen DA. Relationship of calcified lesions to clinically significant atherosclerotic lesions. Ann NY Acad Sci 1968 149:752-67.

20. Jie K-SG, Bots ML. Vermeer C, Witteman JCM, Grobbee DE. Vitamin $\mathrm{K}$ status and osteocalcin levels in women with and without atherosclerosis: a population-based study. In press: Atheroslerosis 1995. 
21. Hoes AW. Grobbee DE, Nalkenburg HA Lubsen I. Hofman A. Cardiovascular risk and atlcause mortality. A twelve-year follow-up study in The Netherlands. Eur J Epidemio! 1993:9:285-92.

22. Witteman JCM, Grobbee DE, Valkenburg HA, van Hemert AM. Stijnen T. Hofman A Cigarette smoking and the development and progression of aortic atherosclerosis. A 9-year population-based follow-up study in women. Circullation 1993;88:2156-62.

23. Löwik MRH, Schrijver J, Odink J, van den Berg H. Wedel M, Hermus RJJ. Nutrition and aging: nutritional status of "apparently healthy"elderly. I Am Coll Nutr 1990:9:18-27

24. Ooms ME. Osteoporosis in elderly women [thesis]. Amsterdam: Vrije Universiteit, 1994

25. Hyman JB, Epstein FH. A study of the correlation between roentgenographic and post-mortem

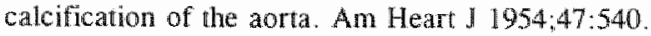

26. Witteman ICM, Grobbee DE. Valkenburg HA, van Hemert AM, Stijnen T, Burger H, Hofman $\mathrm{A}$. J-shaped relation between change in diastolic blood pressure and progression of aortic atherosclerosis. Lancet 1994;343:504-07.

27. Witteman JCM. Kannel WB. Grobbee DE, et al. Aortic calcification plaques and cardiowascular disease (The Framingham Study). Am J Cardiol 1990;66:1060-4.

28. Sitomen $\mathrm{O}$, Uusitupa M, Pyörälä K, at al. Aortic calcification and their relationship to coronary heart disease and cardiovascular risk factors in patients with newly diagnosed non-insulin dependent diabetes and in non-diabetic subjects. Cardiology 1987;74:335-9.

29. Johnston $\mathrm{CC}$, Longcope $\mathrm{C}$. Premenopausal bone loss, a risk factor for osteoporosis. N Eng J Med 1990;323:1271-2.

30. Wasnich R. Bone mass measurement: prediction of risk. Am J Med 1993;95 (Suppl 5A):6S$10 \mathrm{~S}$.

31. Szulc P, Chapuy MC, Meunier PJ, Delmas PD. Serum undercarboxylated osteocallcin is a marker of the risk of hip fracture in elderly women. I Clin Invest 1993;91:1769-74.

32. Sculz $\mathrm{P}$, Arlot $M$, Chapuy MC, Duboeuf F, Meunier P, Delmas P. SErum undercarboxylated osteocalcin correlates with hip bone mineral density in elderly women. IBone Miner Res 1994:9:1591-5.

33. Elkeles A. A comparative radiological srudy of calcified atheroma in males and females over 50 years of age. Lancet 1957; ii:714-5.

34. Anderson JB, Barnet: E. Nordin BEC. The relation between osteoporosis and aortic calcification. Brit J Radiol 1964:37:910-12.

35. Frye MA. Melton III LI, Bryan SC, Fitzpatrick LA, Walmer HW, Schwarz RS, Riggs BI. Osteoporosis and calcification of the aorta. Bone Miner 1992:19:185-94.

36. Ouchi $Y$, Akishita M, Souza de AC. Nakamura T, Orimo H. Age-related loss of boule mass and aortic/aordic valve calcification, reevaluation of recommended dietary allowance of calcium in elderly. Ann NY Acad Sci 1993;676:297-307.

37. Browner WS Pressman AR, Nevitt MC, Cauley JA, Cummings SR. Association between low bone density and stroke in elderly women. Stroke 1993:24:940-6.

38. Compsion IE, Silver AC. Croucher PI, Brown RC. Woodhead JS. Elevated serum inact parathyroid homone levels in elderly patients with hip fracture. Clin Endocrin 1989;31:667-72.

39. Minisola S. Camevale V. Pacíri MT. Romagnoli E. Scarmecchia L, Rosso R. Minisola $G$, Mazzuoli GF. Serum osteocalcin in metabolic diseases: what is its real significance ? Endow crin Inwest 1993; 16:277-9.

40. Sinha TK, Thajchayapong P, Qeener SF. Allen DO, Bell NH, On the lipolytic action of parathyroid hormone in man. Metabolism 1976;25:251-60.

41. Hypertriglyceridaemia and vascular risk. Report of a meeting of physicians and Scien tists. [clinical conference] Lancer 1993;342:781-87. 
42. Walson KE. Boströn K, Ravindranath $R$, Lam $T$, Norton $B$, Demer LJ. TGF- $\beta$. and 25hydroxycholesterol stimulate osteoblast-like vascular cells to calcify. I Clin Invest $1994 \cdot 93: 2106-13$

43. Otawara $Y$, Price PA. Developnental appearance of matrix Gla-protein during calcification in the rat. J Biol Chem 1986;261:10828-32.

44. Pettifor $\mathrm{M}$, Benson $\mathrm{X}$. Congenital nalformations associated with the administration of oral anncoagulants during pregnancy. I Pediatr 1975,86:459-62.

45. Price PA, Lothringer JW, Baukol SA, Reddi AH. Developmental appearance of the witamin $K$ dependent protein bone during calcification: analysis of mineralizing tissues in human, calf, and rat. J Biol Chem 1981,256:3781-4.

46. Vermeer $\mathrm{C}$, Jie $\mathrm{K}-\mathrm{SG}$, Knapen $M H J$, Role of vitamin $K$ in bone metabolism. Annu Rev Nutr 1995. Accepted for publication. 


THE ISOLATION OF $\gamma$-CARBOXYGLUTAMIC ACID (GLA) - CONTAINING PROTEINS

7.1 A SPECIFIC COLORIMETRIC STAINING METHOD

7.2 GLA PROTEINS IN ATHEROSCLEROTIC CALCIFICATIONS 



\section{A SPECIFIC COLORIMETRIC STAINING METHOD FOR $\gamma$-CARBOXYGLUTAMIC ACID-CONTAINING PROTEINS IN POLYACRYLAMIDE GELS}

Kon-Siong G. Jie, Birgit L.M.G. Gijsbers, Cees Vermeer

Department of Biochemistry and Cardiovascular Research Institute Maastricht, University of Limburg. The Netherlands.

\section{SUMMARY}

In this paper we describe a specific staining method for $\gamma$-carboxyglutamic acid (Gla)-containing proteins in polyacrylamide gels. The procedure is based on the colorimetric detection of Gla using 4-diazobenzenesulfonic acid and has the advantage of being simple and fast $(1 \mathrm{~h})$. The detection limit is 9.4 pmol for prothrombin and $150 \mathrm{pmol}$ for osteocalcin. It is demonstrated that Gla-proteins can be visualized independent of the presence of an excess of contaminating nonGla-proteins. The technique may be used for screening of large number of fractions during the purification of Gla-proteins from complex protein mixtures.

Published in: Analytical Biochemistry 1995;224:163-5. 


\section{INTRODUCTION}

Vitamin $\mathrm{K}$ is an essential cofactor in the formation of the unusual amino acid $\gamma$ carboxyglutamate (Gla). 'The vitamin K-dependent enzyme system ( $\gamma$-glutamyl carboxylase) has been identified in nearly all mammalian tissues and cell types. It is at least remarkable that at this time not more than 9 different Gla-proteins have been purified and characterized to a molecular level. Apparently only low amounts of Gla-proteins are produced in other tissues than liver and bone. Therefore, sufficiently sensitive techniques wil] have to be developed to allow for their detection. The discovery of Gla has been hampered for a long time by its decarboxylation under the acid conditions generally applied for protein hydrolyses and subsequent amino acid analysis. In 1977 it was described that this problem could be overcome simply by applying alkaline conditions for the hydrolysis of proteins. ${ }^{2}$ Since then several methods have been described varying from precolumn derivatization followed by HPLC detection to incorporation of ${ }^{3} \mathrm{H}$ into the $\gamma$ carbon of Gla. ${ }^{4.5}$ These methods, however, are all relatively time-consuming and only applicable to hydrolysates. In 1981 Pecci and Cavallini reported a colorimetric method based on the conversion of Gla to a proline derivative using acetaldehyde. "Colorimetric assays using 4-diazobenzenesulfonic acid (DBS) have been described for the detection of Gla in protein hydrolysates as well as in solutions and Western blots. ${ }^{78}$ We have adapted the latter method ${ }^{8}$ and have made it directly applicable for SDS-PAGE gels. Our procedure for the detection of Glaproteins is quick and simple and may be used, for example, for the rapid screening of large numbers of fractions during protein purification.

\section{MATERIALS AND METHODS}

\section{Materials}

4-Diazobenzenesulfonic acid was obtained from FLUKA. Trizma base, dithiothreitol (DTT) were both purchased from Sigma. Sodiumnitrite, EDTA, $\mathrm{NaOH}$, acetate buffer, and citrate were products from Merck. Electrophoresis reagents and protein molecular weight standards were from Bio-Rad.

Bovine prothrombin was a kind gift from Mrs. J. Govers (University of Limburg, Maastricht). Bovine osteocalcin was purified as previously described. ${ }^{9}$ The QAE-Sephadex extract of human calcified atherosclerotic plaques was prepared as described previously. A barium citrate extract was made from human plasma in order to concentrate the various Gla-proteins present." 


\section{Procedures}

Gel electrophoresis was performed under reducing conditions according io Laemmli, on $15 \%$ polyacrylamide gels in the Bio-Rad minigel system. ${ }^{12}$ Prom teins were blotted from the gels on PVDF membranes (Applied Biosystems) in a Bio-Rad Mini Trans-Blot Cell system.

DBS was washed by repeated suspension and centrifugation in ice-cold acetone until no major color change was observed in the supernatant. The DBS was dried and used for the DBS staining solution containing $8.5 \mathrm{mM} \mathrm{DBS}, 6.4$ $\mathrm{mM} \mathrm{NaNO}_{3}$ in $2 \mathrm{M}$ acetate buffer ( $\mathrm{pH} 4.6$ ) as described by Nishimoto. Immediately after gel electrophoresis the gels were washed three times for a period of 5 min in 50\% methanol, $10 \%$ acetic acid to fix the proteins and to remove SDS. The gels were then stained in approximately $50 \mathrm{ml}$ DBS staining solution under gentle agitation for $2 \mathrm{~h}$ at room temperature and in the dark. Subsequently, the staining solution was decanted and the gels were incubated in developing solution consisting of $24 \mathrm{ml} 12.5 \mathrm{M} \mathrm{NaOH}$ and $3.8 \mathrm{ml} 0.5 \mathrm{M}$ EDTA. After gentle shaking in the dark for at least $30 \mathrm{~min}$, the wet gels were ready to be photographed. Relatively weak red color staining, although readily visible in the gel, were rather faint after being photographed. For this reason black and white photographs were taken on a high-contrast film (Technical Pan obtained from Kodak). For the preservation the gels were dried on filter paper backing using a gel dryer, both obtained from Bio-Rad. It should be noted that a rapid crystallization of $\mathrm{NaOH}$ salts can be prevented by sealing the dried gel in plastic.

\section{RESULTS AND DISCUSSION}

\section{Establishment of optimal staining conditions}

Initially, the visibility of the specific red Gla staining was hampered by a yellowred background staining. Thorough washing of the DBS with cold acetone before use and washing of the gel prior to the DBS-staining procedure appeared to be an important step for reducing the background color of the gel. After the addition of the developing solution the gel tends to shrink, which slightly increases the color intensity. Long incubation periods ( $>2 \mathrm{~h}$ ) are not recommended as they lead to an expansion of the gel. For photographic recording we recommend photographing of the wet gel immediately after a developing period of $0.5-\mathbb{h}$. Thereafter, the gel can be dried on paper and preserved (in the dark) for at least 12 weeks, without notable loss of color.

The optimal conditions for the detection of Gla-proteins in polyacrylamide gels were assessed in a $(1: 1 \mathrm{w} / \mathrm{w})$ mixture of two purified Gla-proteins: 


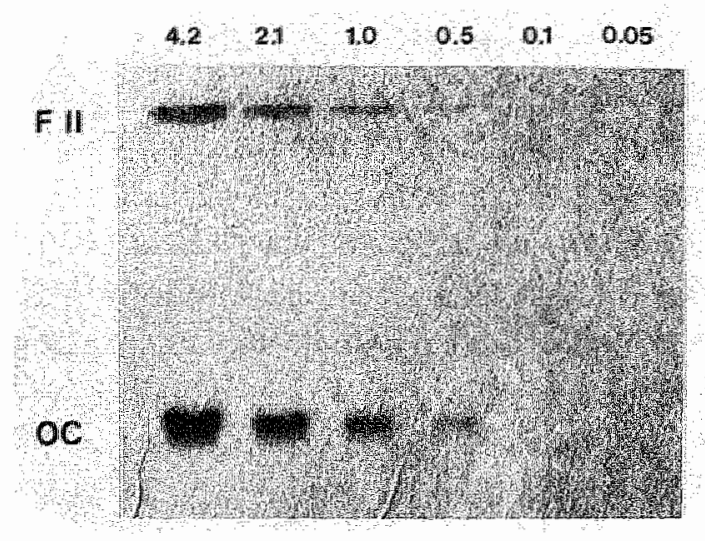

Figture 1. DBS staining of a (1.I w/w) mixture of purified prothrombin (FI) and osteocalcin $10 C$ in a $15 \%$ polyacrylamide gel. dried on paper. The numbers above each lane depict the amount ( $\mu$ g/lane) of each protein loaded on the gel.

prothrombin ( $\mathrm{M}_{\mathrm{r}} 72 \mathrm{kDa}, 10$ Gla resiclues) and osteocalcin ( $\mathrm{M}_{\mathrm{r}} 5.8 \mathrm{kDa}, 3 \mathrm{Gla}$ residues). Gla-proteins stain red, whereas proteins not containing Gla obtain a yellow color with the DBS-staining method. The detection limit of the yellowstained non Gla-proteins, as assessed with bovine serum albumin, is approximate-

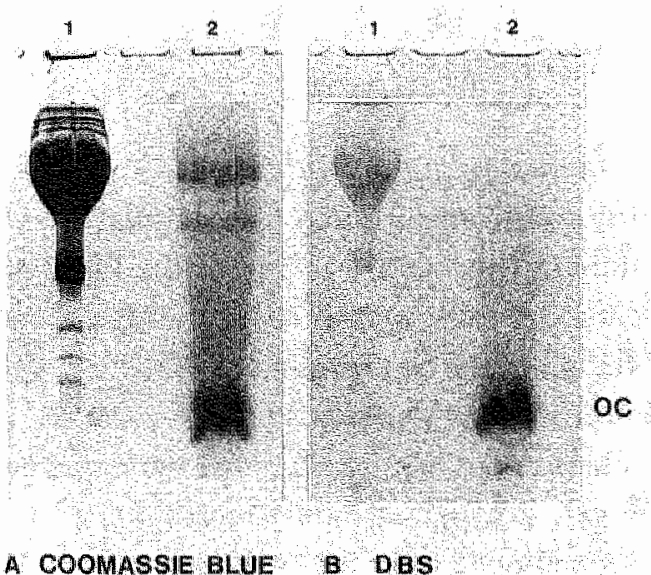

Fignere 2. Specificity of the DBS staining in two protein minures. A is a Coomassie bluestained gel. kawe 1: 1:10 diluted plasna: lane 2: QAE-Sephadex bone extract. B is stained according to the DBS-method: lane 1: 1:10 diluted plasma: lane 2: QAE Sephadex bone exiract; $O C=$ asteocalcin. 


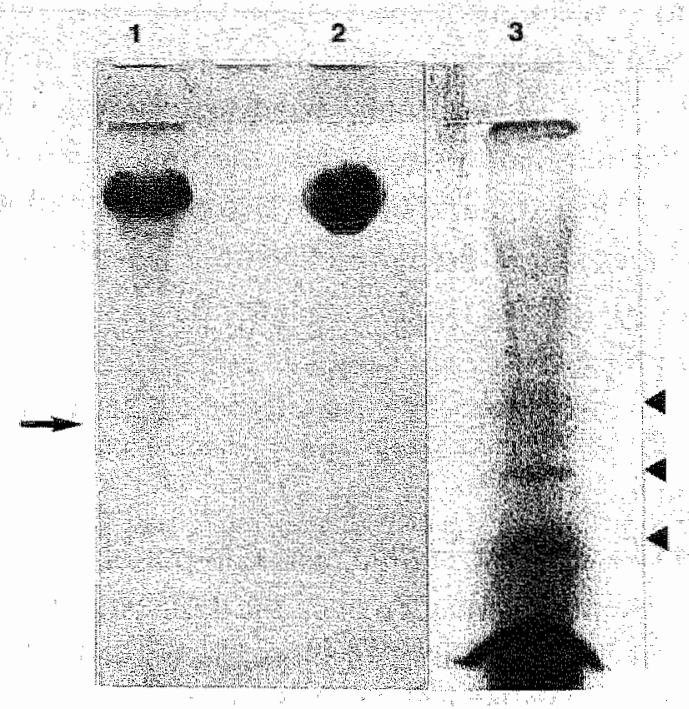

Figure 3. DBS staining of extracts from plasma and Jwman calcified atherascleroric piaques. Lane l: barim citrate plasma exract: lane 2: as in lane l. but umeduced get. $\rightarrow$ = low chain $F X$ : lane 3: QAE. Sephadex extract of hwman calcified atherosclerotic plaques. $=$ Gla-proteins of approxinately 10,18 , and 27 $k D a$.

ly $5 \mu \mathrm{g}$ (data not shown). A false-positive staining appearing as a diffuse area in the low molecular region was observed with $\beta$-mercaptoethanol but not with DTT $(10 \mathrm{mM})$ as a reductant. The detection limits of prothrombin and osteocalcin were $9.4 \mathrm{pmol}(0.68 \mu \mathrm{g})$ and $150 \mathrm{pmol}(0.87 \mu \mathrm{g})$, respectively (Figure 1$)$. This is comparable to the results reported for the Western blot procedure (osteocalcin: $1 \mu \mathrm{g}$ or $170 \mathrm{pmol}) .{ }^{8}$ The detection limits found for prothrombin and osteocalcin are not comparable, although the molar amount of Gla in prothrombin is 3.3 times higher than that in osteocalcin. This apparent discrepancy obtained with DBS staining has been reported earlier.

\section{Specificity of the DBS staining}

The specificity of the DBS staining is demonstrated best when applied to several complex protein samples. A QAE-Sephadex bovine bone exiract showed one Glacontaining (osteocalcin) protein after staining with DBS (Figure $2 \mathrm{~B}$, lane 2). Coomassie staining showed a major band at the same position, but several other non-Gla-containing protein bands to be present (Figure 2A, lane 2). DBS-staining of human plasma (1:10 diluted), on the other hand, did not show any Gla-containing protein bands to be present (Figure $2 \mathrm{~B}$, lane 1). In order to enrich the plasma sample in Gla-proteins, adsorption to barium citrate and subsequent elution was performed. A barium citrate extract of human plasma showed the existence of a prominent Gla-protein at approximately $72 \mathrm{kDa}$, whereas a faint red staining was observed at $25 \mathrm{kDa}$ (Figure 3 , lane 1). Additional analysis with 
specific antibodies showed a positive reaction of the $72 \mathrm{kDa}$-band with antiprothrombin and of both the $25-\mathrm{kDa}$ and $60-\mathrm{kDa}$ with antifactor $\mathrm{X}$ (data not shown). The fact that in a non-reducing gel the 25 - $\mathrm{kDa}$ protein band had migrated to 60 $\mathrm{kDa}$ (Figure 3, lane 2) was an indication that this band was the light chain of the blood coagulation factor X. Finally, DBS staining of a QAE-Sephadex extract of human calcified atherosclerotic plaques showed the presence of at least three Glaproteins of approximately 27,18 , and $10 \mathrm{kDa}$ (Figure 3 , lane 3 ).

\section{CONCLUSIONS}

In this paper we describe a method for specific staining of Gla-proteins in polyacrylamide gels. Our method has several advantages over the DBS staining procedure recently described for Western blots. First, in blots the optimal blotting time for each protein varies with the molecular weight of the protein, which may drastically influence the efficiency of the protein transfer, notably in complex mixtures. With our method there is no loss of (unknown amounts of) proteins, which makes the evaluation of heterogenous Gla-proteins of different molecular weights much easier. Second, in contrast to the blots, the gels can be preserved for at least 12 weeks without notable color loss by drying the gels on filter backing paper. The gel staining method is also much quicker ( 1 h staining instead of overnight). Finally, non Gla-proteins ( $>5 \mu \mathrm{g} / \mathrm{band}$ ) are also detected with our staining procedure, but in a different color.

With this technique we have shown the occurrence of several Gla-containing proteins in barium citrate enriched plasma, as well as in QAE-Sephadex extracts from bone and human calcified atherosclerotic plaques. The DBS-gel staining method appears to be a rapid and sensitive method for the assessment of Glaproteins in crude protein mixtures.

\section{REFERENCES}

1. Vermcer $\mathrm{C}$. $\gamma$-Caboxyglutanate-containing proteins and the witamin $\mathrm{K}$-dependent carboxylase. Biochem I 1990;266:625-6.

2. Hauschka PV. Quantative determination of $\gamma$-carboxyglutamic acid in prote ins Anal Biochem $1977 ; 80: 212-23$.

3. Kuwada M, Katayama K. An improved method for the determination of $\gamma$-Carboxyglutamic acid in proteins, bone, and urine. Anal Chem 1983;131:173-9

4. Hauschka PV. Specific tritum labeling of gamma-carboxyglutamic acid in proteins. Biochemistry 1979:18:4992-9. 
5. Nelsesmen GL. Methods in Enzymology. In: Wold F, Moldare K. editors. San Diego: Acadenic Press, $1984 ; 104: 503-7$.

6. Pecci L, Cavallini D. A colorimetric procedure for the dletermination of $\gamma$ carboxyglutamic acid. Anall Biochem 1981;118:70-5.

7. Danielson, ND, Wu, Y-P, Morgan, D.K. Colorimetric determination of $\gamma$-Carboxyglutamie acid in the presence of other amino acids. Anal Chem 1985;57:185\%8.

8. Nishimoto, SK A colorimetric assay specific for $\gamma$ (Carboxygluamic acid-containing proteins: its utility in protein purification procedures. Anal Chem 1990:186:273-9.

9. Vermeer C, Soute BAM, Hendriks H, de Boer - van den Berg MAG. Decarboxylated bone Giaprotein as a substrate for hepatic vitamin $\mathrm{K}$-dependent carboxylase.

10. Gijsbers BLMG, van Haanlem LJM, Soute BAM, Ebberink RHM, Vermeer C Characterization of a Gla-containing protein from calcified human atherosclerotic plaques. Arteriosclerosis $1990 ; 10: 991-5$.

11. Di Scipio RG, Hermodson MA, Yates SG, Davie EW. A comparison fo human prothrombin. factor IX (Christmas factor), factor X (Stuart factor), and protein S. Biochemistry 1977;16:698706.

12. Laemmli UK. Cleavage of structural proteins during the assembly of the head of bacteriophage T4. Nature 1970;227:680-5. 



\title{
GAMMA-CARBOXYGLUTAMIC ACID (GLA)-CONTAINING PROTEINS IN ATHEROSCLEROTIC CALCIFICATIONS OF THE HUMAN VESSEL WALL
}

\author{
Kon-Siong G. Jie, ${ }^{1}$ Birgit L.M.G. Gijsbers ${ }^{1}$ Monique M.C.L. Groenen - van \\ Dooren, ${ }^{1}$ Rob H.M. Ebberink, ${ }^{2}$ and Cees Vermeer ${ }^{1}$ \\ 1 Department of Biochemistry and Cardiowascular Research Institute Mastricht, University of \\ Limburg, Maastricht, The Netherlands \\ 2 Applied Biosystems, Perkin-Elmer Corporation, Gouda, the Netherlands
}

\section{SUMMARY}

Vitamin K-dependent or $\gamma$-carboxyglutamic acid (Gla) containing proteins are probably involved in the mineralization process in the atherosclerotic vessel wall. Although several new Gla-proteins have been identified in atherosclerotic calcifications, none of them have been purified to homogeneity. In this study we describe the presence of protein-bound Gla of approximately 10, 18 and $27 \mathrm{kDa}$ in the calcified atherosclerotic plaque. The isolation and characterization of these proteins is greatly hampered by considerable losses during each fractionation. An explanation may be found in the concomitant extraction of interfering components such as negatively charged proteoglycans. 


\section{INTRODUCTION}

The unusual calcium binding amino acid $\gamma$-carboxyglutamate (Gla) was initially shown to be present in blood coagulation factors. ' A few years later, it was revealed that Gla residues are not confined to proteins involved in blood coagulation but are also present in a number of proteins located in sites of physiological and pathological mineralizations including those found in bone tissue, calcium containing renal stones and skin exsudates, calcified heart valves, and the calcified atherosclerotic plaque. ${ }^{2,3,4,5}$

During the vitamin $\mathrm{K}$-dependent carboxylation reaction, certain protein-bound glutamate residues are converted into Gla. ${ }^{6}$ The Gla residues seem to be essential for the biological activity of Gla-proteins, and their presence substantially contribute to the calcium binding capacity of these proteins. The function of Gla-proteins associated with atherosclerotic calcifications is not precisely known. Interestingly, the bone Gla-proteins osteocalcin and MGP have both been identified in atherosclerotic calcifications. ${ }^{7,8.9}$ Since in bone tissue these proteins are thought to be involved in the regulation of the calcification process, it is tempting to assume a similar function in the atherosclerotic vessel wall. ${ }^{2.9}$ Recent studies indicate that also other (non-Gla containing) matrix proteins normally found in bone tissue, are actively involved in the plaque mineralization process..$^{9.10_{n} 1 \mathrm{f}}$

Gla-proteins reported to be present in atherosclerotic calcifications vary widely in their molecular range: $6-10,{ }^{7,8,12} 80 \mathrm{kDa}^{13}$ or $23 \mathrm{kDa} .^{14}$ Whereas some of these Gla-proteins were shown to be similar to osteocalcin, ${ }^{27,8}$ others apparently were an artifact of the isolation procedure (atherocalcin, $80 \mathrm{kDa}$ ). ${ }^{15}$ The three Gla-proteins found in bone tissue, osteocalcin, MGP and protein $\mathrm{S}^{16}$ are well characterized. The isolation of Gla-proteins found in the calcified plaque, on the other hand, has been hampered by poor reproducibility and very low yields of various fractionations. The study presented here was undertaken to improve the isolation and characterization of the Gla-proteins present in the EDTA-soluble fraction of the calcified plaque.

\section{METHODS}

\section{Materials}

Guanidine hydrochloride (guanidine $\mathrm{HCl}$ ), aprotinin, and human serum albumin (HSA), p-hydroxymercuribenzoic acid, phenylmethylsulfonyl fluoride (PMSF), 6-aminocaproic acid EDTA, Trizma base and Bis-Tris were obtained from Sigma (Saint Louis, MO). 6-Aminocaproic acid and PEG 20000 were purchased 
from Fluka Chemica (Buchs, Swizerland). QAE-sephadex, Mono Q HR 5/5 and Protein G Superose HR 10/2 columns were from Pharmacia (Uppsala, Sweden). Benzamidine hydrochloride was a product of Janssen Chumica (Beerse, Belgium) and urea was from Merck (Darmstadi). Spectrapor dialysis tubing (molecular weight cutoff, $3.5 \mathrm{kDa}$ ) was purchased from Spectrum Industries (Los Angeles, CA). 0-Phtaldehyde (OPA) was obtained from Pierce (Rockford, $\mathbb{1 1}$ ) and acetronitrile (HPLC grade) was from Rathburn (Walkerburn, Scotland). All chemicals used were of analytical grade. Purified human prothrombin was kindly provided by Mrs T. Janssen (University of Limburg, Maastricht), polyclonal antibodies against FX and FII purified by affinity chromatography were a gift from dr. T. Lindhout (University of Limburg, Maastricht).

\section{Exiraction of calcified plaques}

Human atherosclerotic aortas were obtained at autopsy and frozen within 12 h after death $\left(-80^{\circ} \mathrm{C}\right)$. None of the donors had been treated with oral anticoagulants. The investigation protocol had been approved by the University Hospital Ethics Committee. For a standard extraction procedure 60-120 storta's were used, which resulted in approximately $100 \mathrm{~g}$ calcified material. The procedure consisted of thawing of the aorta's, careful dissection of the calcifications from surrounding non-mineralized tissue, and pooling of all the calcified plaques. The plaques were extensively washed in buffer A $(0.02 \mathrm{M}$ Tris, $0.05 \mathrm{M} \mathrm{NaCl}$. $\mathrm{pH} 7.5)$, delipidated 3 times in acetone, chloroform/methanol $(2: 1, \mathrm{v} / \mathrm{v})^{17}$ and once in acetone (each washing step lasted $12 \mathrm{hrs}$ at room temperature), air-dried and subsequently milled to powder in liquid nitrogen using a Spex impact Mill. Proteins were extracted during 2-3 days at $4{ }^{\circ} \mathrm{C}$, by continuously stirring the powder in buffer $\mathrm{B}(1.0 \mathrm{M}$ EDTA, $0.2 \mathrm{M} \mathrm{KCl}, \mathrm{pH} 8.0)$ including protease inhibitors $(0.01 \mathrm{M}$ benzamidine $\mathrm{HCl}, 0.05 \mathrm{M}$ 6-aminocaproic acid, $10 \mathrm{KIU}$ aprotinin, $0.01 \mathrm{M}$ PMSF and $0.01 \mathrm{M} p$-hydroxymercuribenzoate). After centrifugation ( $1500 \mathrm{~g}, 30 \mathrm{~min}, 4^{\circ} \mathrm{C}$ ) of slurry, the non-solubilized material was subjected to at least two more extraction procedures. Pooled EDTA-extracts were diluted 20 fold in distilled water $\left(4^{\circ} \mathrm{C}\right.$ ) and absorbed batchwise to QAE-sephadex preswollen in buffer $\mathrm{A}(10 \mathrm{ml}$ of preswollen slurry per liter diluted extract). The absorbed proteins were eluted with $1.0 \mathrm{M} \mathrm{NaCl}$ in buffer $\mathrm{A}$, dialysed extensively in buffer $\mathrm{C}(0.02 \mathrm{M}$ Bis-Tris, $0.05 \mathrm{M} \mathrm{NaCl}, \mathrm{pH} \mathrm{7.0)}$, concentrated in $30 \% \mathrm{PEG}$, buffer $\mathrm{C}$ and dialysed again. Finally, protein concentration was determined according to Sedmak and Grossberg. ${ }^{18}$ The solution thus obtained will be referred to as the plaque extract. 


\section{Column chromatography}

Chromatography was performed using a Separations HPLC High Precision pump, Model 480 . The plaque extract was applied on a Mono-Q anion-exchange column, equilibrated with buffer $\mathbb{C}$, elution was performed with a linear gradient from 0.05 to $1.0 \mathrm{M} \mathrm{NaCl}$ in buffer C. Elution profile was monitored at $280 \mathrm{~nm}$ using a UV-detector (Separations, Model 759A absorbance detector).

\section{Gla-determination}

For the detection of Gla, samples were subjected to alkaline hydrolyses for $16 \mathrm{hrs}$ in $2.0 \mathrm{M} \mathrm{KOH}$, in vacuo in sealed glass tubes, at $110^{\circ} \mathrm{C}$. The method used is based on a precolumn derivatization with OPA and subsequent HPLC separation (Separations, High Precision Pump Model 300) using a Nucleosil 5B column (Gimex, Netherlands) at $47^{\circ} \mathrm{C}$ as described by Kuwada and Katayama. ${ }^{19}$ The identity of Gla was determined by comparing the elution time with that of purified Gla and the disappearance of the Gla-peak after acid hydrolyses. For the determination of the Gla-concentration, a reference curve of known amounts of purified Gla was used. The purification procedure of Gla-proteins was monitored by assessing the Gla/Glu ratio of the hydrolysed sample: samples enriched in Glaproteins demonstrated an increase in the Gla/Glu ratio. Immunoreactive osteocalcin levels were determined with the radioimmunoassay (RIA) kit from INCSTAR (Stillwater, MI).

\section{Digestive enzymes}

Trypsin (EC 3.4.21.4), chymotrypsin (EC 3.4.21.1), neuraminidase type III (EC 3.2.1.18) and alkaline phosphatase from bovine intestinal mucosa (EC 3.1.3.1.) were from Sigma (Saint Louis, MO). Chondroitinase ABC protease free (EC 4.2.2.4) and hyaluronidase type $V$ (EC 3.2.1.35) were purchased from Boehringer Mannheim.

Trypsin digestion was performed in $0.05 \mathrm{M}$ Tris buffer, pH 8.5 at 1:1000 $(\mathrm{w} / \mathrm{w}), 1: 100(\mathrm{w} / \mathrm{w}), 1: 20(\mathrm{w} / \mathrm{w})$ for varying time intervals up to $4 \mathrm{hrs}$, at $37^{\circ} \mathrm{C}$. Chymotrypsin digestion was performed in $0.05 \mathrm{M}$ Tris, pH 8.0 at $1: 1000(\mathrm{w} / \mathrm{w})$, 1:100 (w/w) or $1: 20(\mathrm{w} / \mathrm{w})$ at $37{ }^{\circ} \mathrm{C}$ for up to 4 hrs. For both enzymes the effect of an incubation period of $24 \mathrm{hrs}$ at $37{ }^{\circ} \mathrm{C}$ was also evaluated. Hyaluronidase digestions were performed $(100 \mathrm{U} / \mathrm{mg})$ under several conditions: in buffers of $0.05 \mathrm{M}$ sodium acetate $\mathrm{pH} 5$, and $0.05 \mathrm{M}$ sodium phosphate $\mathrm{pH} 6,7$ or 8 for $1 \mathrm{~h}$ at $37^{\circ} \mathrm{C}$ in the presence of a protease inhibitor $(0.01 \mathrm{M} \mathrm{6-aminocaproic} \mathrm{acid)}$ and/or $0.1 \%$ SDS. All other enzymatic digestions were used according to the manufacturer"s description. 


\section{Antibodies}

Polyclonal antibodies were raised in rabbits by emulsifying the protein in Freund's complete adjuvant (Difco Laboratories, Detroit, USA) and immunizing the animals with several intradermal and one intraperitoneal injection. Booster injections in Freund's incomplete adjuvant were given at 3 week intervals. $\operatorname{IgG}$ was purified from immunized sera by protein $\mathrm{G}$ affinity chromatography.

\section{Gel electrophoresis}

Gel electrophoresis was performed according to Laemmli ${ }^{20}$ or Shägger ${ }^{21}$ using the Bio-Rad Mini Gel System. Slab gels were either $15 \%$ or $10 \%$ and stained with Coomassie Brilliant Blue (CBB), Silver Stain Plus, DBS (4-diazobenzenesulfonic acid) or Stains All (all from Bio-Rad). A specific colorimetric (DBS) staining for Gla-proteins in polyacrylamide gels was performed as described previously. ${ }^{22}$ The Stains All staining was performed according to Campbell et $a l^{23}$ with the following modification: immediately after electrophoresis the gel was fixed in fixing solution $(50 \%(\mathrm{v} / \mathrm{v})$ methanol, $10 \%(\mathrm{v} / \mathrm{v})$ acetic acid) over night at room temperature, followed by extensive washing in freshly made fixing solution. This staining procedure has been optimized for the blue-staining of $\mathrm{Ca}^{2+}$-binding proteins, while other proteins stain red. For the staining of glycoproteins the Periodic acid-silver staining according to Dubray was used. ${ }^{24}$ Electroblotting was performed on PVDF membrane (Problott ${ }^{\mathrm{TM}}$, Applied Biosystems) in a Bio-Rad mini transblot cell system. Electroblotted (glyco)proteins were stained with the 'DIG Glycan/protein double labeling' kit (Boehringer Mannheim). Preparative gel electrophoresis was performed with the Prep Cell, Model 491 obtained from Bio-Rad (Richmond, CA). A $10 \%$ resolving gel (0.375 $\mathrm{M}$ Tris, pH 8.8) was casted using a $37 \mathrm{~mm}$ ID column and led to polymerize overnight. The $4 \%$ separating gel consisted of $0.125 \mathrm{M}$ Tris, $\mathrm{pH} 6.8$, the elution buffer consisted of $0.02 \mathrm{M} \mathrm{NH}_{4} \mathrm{HCO}_{3}, \mathrm{pH} 7.5$.

\section{Protein sequencing}

Samples were electrophorised in a $15 \%$ SDS-polyacrylamide gel, using PDA (Bio-Rad) instead of bisacrylamide. The proteins were electrophoretically transferred on a PVDF membrane in $90 \mathrm{~min}, 150 \mathrm{~mA}$. The transfer buffer consisted of $0.01 \mathrm{M}$ CAPS (Aldrich, Milwaukee) at $\mathrm{pH} 9-11,10 \%$ methanol. Blotted proteins were sequenced using an Applied Biosystems Protein Sequencer, Model $473 \mathrm{~A}$. 


\section{RESULTS}

\section{Optimalisation extraction procedure}

The extraction procedure was performed according to Gijsbers et al. ${ }^{14}$ with the following modifications: the calcified plaques were delipidated once in aceton, three times in choloroform/methanol $(2: 1 \mathrm{v} / \mathrm{v})$ and finally once more in aceton. With this procedure the lipids on the surface of the plaques were removed. The addition of 4-6 M Guanidine- $\mathrm{HCl}$ or $6 \mathrm{M}$ Urea to the extraction-buffer did not lead to an increased yield or purification of Gla-proteins i.e. an increase in the absolute amount of Gla or Gla/Glu ratio present in (fractions of) the plaque extract and was therefore omitted. Also delipidation of the plaques with freon did not have a favourable effect. The grinding procedure of the plaques with a Spex impact Mill, generally lead to a $5-7 \%$ loss of plaque material. The protein yield of the plaque extract was $0.30 \mathrm{mg} \pm 0.10$ (SD) protein/g plaque, with a mean concentration of $1.57 \pm 0.22 \mathrm{nmol} \mathrm{Gla} / \mu \mathrm{g}$ protein or $0.48 \pm 0.02 \mu \mathrm{mol} \mathrm{Gla} / \mathrm{g}$ plaque. The Gla/Glu ratio varied from 0.05-0.07 (Figure 1).

\section{Column chromatography}

When the plaque extract was applied to a Mono-Q anion-exchange column, no significant separation in distinct protein peaks was observed (Figure 2). About $80 \%$ of all protein-bound Gla was equally distributed in the two main peaks. In addition, substantial losses of Gla (up to $60 \%$ !) were noticed after chromatography, without an increase in Gla/Glu ratio in any of the eluted fractions. In order to improve the purification procedure a wide variety of columns were evaluated: ion-exchange (Mono-S), size exclusion chromatography (Superose-12, TSK (SW 2000/3000), Superdex 75), hydroxyapatite, hydrophobic interaction (Protein C4) and reversed phase columns. All of them essentially had the same result, with a chromatogram more or less similar to Figure 1. Several other techniques also

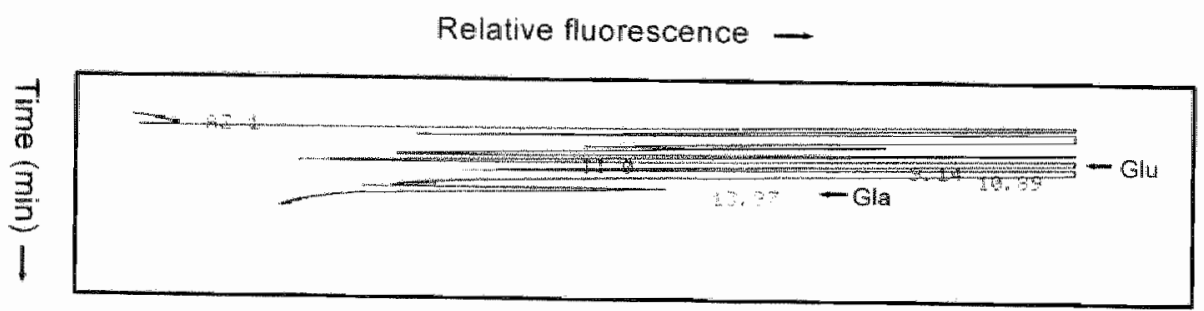

Figure 1. Alypical chromatogram of the Gla-analysis of the plaque erract. Gla elutes at 13.97 min and Gha at 9.14 min. The Gla/Glu ratio of this sample was 0.06 . 


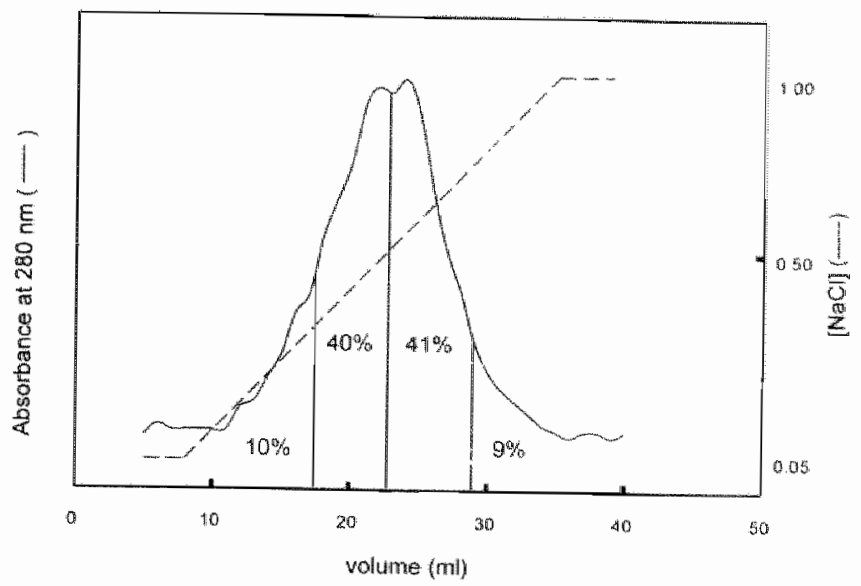

Figure 2. Mono-Q amion exchange chromatography of the plaque extract. Samples were eluted with a linear gradient from 0.05 to $1.0 \mathrm{M} \mathrm{NaCl}$ in buffer $\mathrm{C}$. The percentages in the figure denote the disinbution of Gla present in various fractions, indicating that Gla was mainly present in the two major peaks.

failed to improve the purification of Gla-proteins: the addition of chaotropic agents such as 4-6 M Guanidine HCL or $6 \mathrm{M}$ Urea to buffer $\mathrm{A}$ and protein samples; variations in $\mathrm{pH}$ of the mobile phase; using a gradient of $0-1.0 \mathrm{M}$ $\mathrm{CaCl}_{2}$ as eluent; or variation in the slope of the gradient, using continous and discontinous gradients.

\section{SDS-polyacrylamide gel electrophoresis}

When analyzing the plaque extract on SDS-polyacrylamide gel, a prominent smear was visible in the whole lane of the plaque extract after Coomassie Brillian Blue (CBB) (Figure 3A) or silver staining. In addition, a lew discrete protein bands were visible: the most prominent one of $67 \mathrm{kDa}$ and a weaker staining was observed at approximately $27 \mathrm{kDa}$ (Figure 3A). Electrophoresis in a native or non-reducing gel did not alter the findings of both staining methods, neither did analysis in the presence of $4-6 \mathrm{M}$ Urea (data not shown). The DBS-staining method $^{22}$ revealed the presence of three Gla-proteins of approximately 10,18 and $27 \mathrm{kDa}$ (Figure 3C).

The extraction procedure applied is expected to extract negatively charged $\mathrm{Ca}^{2+}$-binding proteins. We therefore used the cationic carbocyanine dye "Stains All", which stains strong $\mathrm{Ca}^{2+}$-binding proteins, sialic acid-rich proteins and heavily phosphorylated proteins in blue, whereas other proteins are stained in red. ${ }^{23}$ A red protein band was visible at $67 \mathrm{kDa}$ (not apparent on black and white 


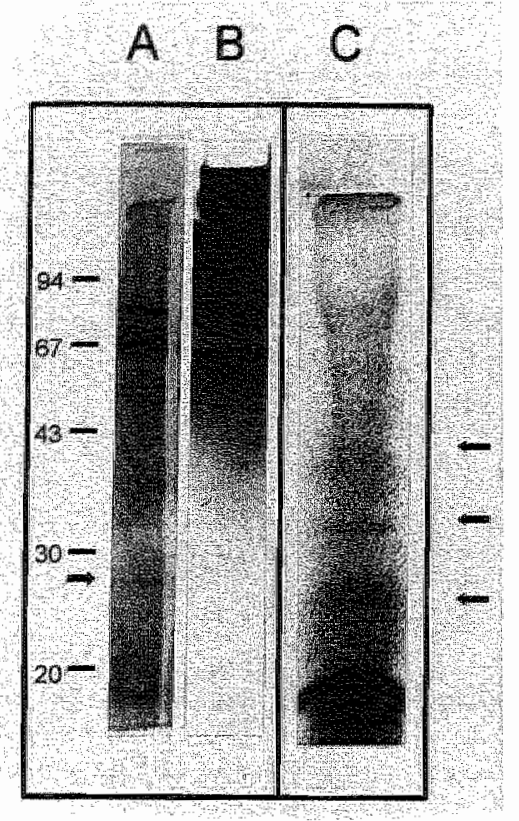

Figure 3. SDS-polyacrylamide get electrophoresis of the plaque exiract. A: Coomassie Brilluan Blue staining of a $12.5 \%$ gel, arrow denotes a 27 kDa protein band (arrow): B: periodic acid staning revealing a smear of carbohydrates; the $67 \mathrm{kDa}$ albumin band did not srain. $C$. $15 \%$ polyacrylamide gel stained with the DBS-staining meihod, due to the different gel percentage and addition of $12.5 \mathrm{M} \mathrm{NaOH}$, the proteins bands are positioned differenty, the three arrows indicate Gla-proteins of approximately 27,18 and $10 \mathrm{kDa}$. respectively.

photography), covered by a blue smear extending across the whole lane. In addition at least three blue-stained bands were visible between approximately 40 and $60 \mathrm{kDa}$ (Figure 4A). While digestion with alkaline phosphatase $\mathrm{e}^{25}$ did not affect the staining patterm, digestion with neuraminidase $\mathrm{e}^{23}$ completely abolished the blue smear (Figure 4B). This indicated that the blue smear did not contain heavily phosphorylated proteins but mainly consisted of sialic-acid rich proteins. ${ }^{23}$ The presence of sialic acid residues was confirmed by staining the electroblotted plaque extract with the DIG-glycan detection kit after mild oxidation with sodium melaperiodate $\left(0.01 \mathrm{M}\right.$ at $0{ }^{\circ} \mathrm{C}$ for $20 \mathrm{~min}$.) (data not shown). Periodic acidsilver staining of the plaque extract confirmed that the smear contained substantial amounts of carbohydrates (Figure 3B). The $67 \mathrm{kDa}$ band (later shown to be human albumin) did not stain, indicating that it lacked carbohydrates. These staining procedures have thus shown that the smear covering the whole lane consists of sialic acid rich glycoproteins or proteoglycans.

Several other enzymatic digestions were tested and evaluated on SDS-polyacrylamide gel by $\mathrm{CBB}$, silver or DBS-staining: trypsin, chymotrypsin, $\mathrm{CNBr}$, hyaluronidase, ${ }^{26}$ chondroitinase $\mathrm{ABC} .{ }^{27}$ None of these digestions, however, lead to the disappearance of the background smear or improved DBS-staining of the Gla-proteins. Neither were there improvements found, by the addition of detergents $(0.1 \%$ SDS or CHAPS) to the sample prior to digestion. Attemps to precipitate the smear or Gla-proteins with aceton ${ }^{28}$ and ethanol ${ }^{29}$ were 


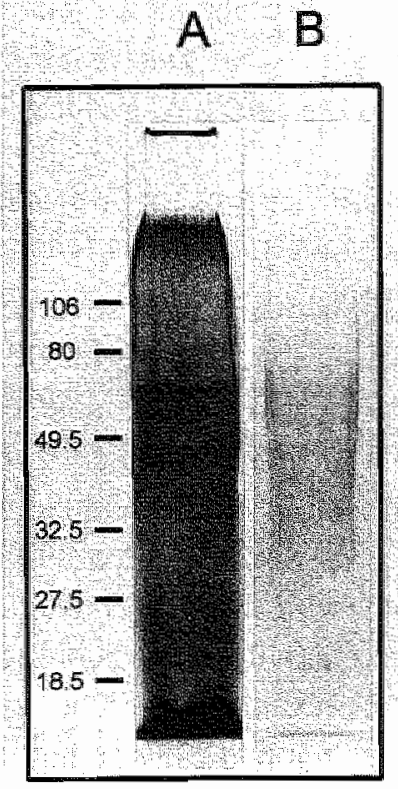

Figure 4. SDS-polyachlanide: gel $(15 \%)$ of the plaque exract stained with srains All, before (A) and afoer (B) neuraminidase digertion.

unsuccessfull. Absorption of the plaque extract either to $\mathrm{BaSO}_{4}{ }^{30}$ or hydroxyapatite $^{31}$ and subsequent elution, also did not lead to an improved purification of Gla-proteins. Mild delipidation with freon had no appreciable effect either.

\section{Sequencing}

A high background signal was obtained when sequencing the $27 \mathrm{kDa}$ protein band. The presence of a high signal indicated that the amount of protein on the blot must have been sufficient to be sequenced. However, no additional sequencing information was obtained, which could be due to $\mathrm{N}$-terminal blockade of the protein. Proteolytical $(\mathrm{CNBr})$ digestion of the blotted protein to overcome this did not improve the results. Several precautions to prevent $\mathrm{N}$-terminal blockade (i.e. chemicals of the highest purity, polymerization of the SDS gel on the day before use, etc) did not alter the findings either. ${ }^{32.33}$ The procedure we used was not responsible for a possible $\mathrm{N}$-terminal blockade, since commercially obtained purified HSA could be sequenced without any problems. Sequencing of other parts of the Western blotted plaque exiract revealed that: 1) the $67 \mathrm{kDa}$ band could be succesfully sequenced despite the presence of a high background signal and had a $\mathrm{N}$-terminal sequence identical to that of HSA;2) the same background signal was present in all parts of the blot containing the smear-like CBB staining; 3) the background was absent in a piece of the blot beneath the front of the lane. These 
results indicate that the background smear present in the plaque extract is the source of the high background sequencing signal and that only proteins of a sufficient high concentration to overcome the interfering signal, for example the human albumin-band, can be sequenced.

\section{Polyclonal antibodies}

Several fractions of the plaque extract isolated by preparative gel electrophoresis were used to raise polyclonal antibodies: a fraction above the $27 \mathrm{kDa}$ band (fraction I), the $27 \mathrm{kDa}$ fraction (fraction II) and background smear between 20 and $25 \mathrm{kDa}$ (fraction III). Preincubation of the IgG antibodies with HSA was performed to overcome an apparent crossreaction of the antibodies with albumin. The antibodies against fraction II and III crossreacted with a $29 \mathrm{kDa}$ band, whereas those against fraction II crossreacted with a $27 \mathrm{kDa}$ band. In a BaCitrate extract of human plasma the same crossreactivity was visible (data not shown). DBS-staining of the gel, however, did not reveal the presence of Gla-proteins in the BaCitrate extracts, indicating that these antibodies were not directed against a Gla-protein or that the assumed Gla-protein is present beneath the detection limit of the DBS-staining method.

\section{Presence of other vitamin $K$ dependent proteins}

Immunoblotting of the plaque extract using antibodies against either prothrombin, coagulation factor $X$ or osteocalcin did not reveal any crossreactivity. Trace amounts of osteocalcin ( $16 \mathrm{ng}$ osteocalcin/mg plaque extract) could be identified by radioimmunoassay.

\section{DISCUSSION}

The atherosclerotic process is attended by complex interactions of various celltypes, including endothelial cells, platelets, macrophages and vascular smooth muscle cells (VSMC's). ${ }^{36}$ Putative functions of these cells include the synthesis of various extracellular matrix components (collagen, elastin, glycoproteins and proteoglycans), often proposed to contribute to lipid accumulation and calcification of the atherosclerotic plaque. ${ }^{34.36}$ The presence and Jocal production of several bone-associated proteins have recently been reported in atherosclerotic lesions. These include type I collagen, bone morphogenetic protein-2a (a potent osteogenic differentiation factor), ${ }^{10}$ osteopontin ${ }^{35}$ and osteonectin. ${ }^{36}$ In addition, the two most common Gla-proteins present in bone, osteocalcin and MGP, have both been identified in the atherosclerotic lesions.9.7.8 These Gla-proteins were 
shown to be closely associated with the calcified deposits in the human atherosclerotic plaque and may be locally produced by a calcifying vascular cell, ${ }^{10,37}$ vSMC's or macrophages. ${ }^{3,59,11,35}$

The analysis of Gla-proteins present in the plaque, is hampered by the difficulty of obtaining sufficient human calcified atherosclerotic plaques and by the relatively low concentration of Gla-proteins present in these lesions. It is not surprising therefore, that the purification of these Gla-proteins has proven to be a laborious task. The many attemps performed in this study have shown that the plaque extract contains at least three Gla-proteins with an apparent molecular weight of 10,18 and $27 \mathrm{kDa}$, albumin and a heterogenous mixture of negatively charged macromolecules of a wide molecular range, rich in carbohydrates and sialic acid.

\section{Gla-proteins}

We have confirmed the presence of protein-bound Gla in calcified atherosclerotic plaques of human origin (Figure 1, 3C). The amount of Gla found $(0.48 \mu \mathrm{mol} / \mathrm{g}$ plaque material) is in accordance with the $0.53 \mu \mathrm{mol} / \mathrm{g}$ plaque previously reported by Price. ${ }^{2}$ It is striking that three Gla-proteins were visible with the DBSstaining method, whereas $\mathrm{CBB}$ and silver staining only confirmed the presence of the $27 \mathrm{kDA}$ Gla-protein (Figure $3 \mathrm{C}$ ). This could be due to the acidic nature of the two other Gla-proteins. It is well known that the latter two procedures may poorly stain acidic amino acids and some calcium-binding proteins. ${ }^{38,39}$ This phenomenon has been described for dog osteocalcin, for instance, which cannot be made visible with silver staining. ${ }^{40}$ Another explanation may be found in components present in the plaque extract, that interfere with or obscure the subsequent (CBB and silver) staining of the two Gla-proteins. Since the DBSmethod specifically stains Gla residues, interference of other (non-Gla containing) proteins is less likely to occur. ${ }^{22}$

Several of our findings are in line with those described by Levy et al. ${ }^{k}$ who reported that 1) the EDTA-soluble extract of the human calcified plaque consists of a heterogenous extract of a wide range of macromolecules giving rise to a chromatogram virtually identical to that of Figure $1 ; 2$ ) the isolation of Glaproteins from the plaque is resistant to biochemical resolution techniques and 3) any fractionation tried was characterized by high losses of protein-bound Gla.

\section{Other components of the plaque extract}

It is still unknown whether human albumin, frequently identified in the EDTAsoluble fraction of the calcified plaque, has a role in the calcification process or is 
merely the result of passive absorption from the circulation. Albumin is known to interact with other (Gla)proteins such as osteocalcin, occasionally leading to artifacts in the isolation procedure. 12.15

A major part of the plaque extract consists of negatively charged glycoproteins or proteoglycans with glycoaminoglycan side chains of varying lengths. Proteoglycans are a well known constituent of intimal atherosclerotic lesions and are thought to be involved in thrombosis, lipid accumulation and calcification of the atherosclerotic plaque. ${ }^{34}$ These macromolecules are of a wide molecular range, appearing as a smear on SDS-polyacrylamide gel electrophoresis, and interacting with a wide variety of proteins present in the plaque extract, ultimately impeding further isolation of the Gla-proteins. We cannot exclude the possibility that, despite the use of protease inhibiters, the plaque extract also contains a mixture of (non-dialysable) protein breakdown products or protein complexes, possibly altered via non-enzymatic glycosylation or proteolysis. This view is supported by the results of the sequencing experiments which indicated that the background smear contained large amounts of negatively charged aminoacids. The previously published aminoacid composition and protein sequence of PGP may therefore be partly derived from these contaminants. ${ }^{14}$

Despite the fact that several studies have shown protein-bound Gla to be present in the atherosclerotic plaque, none of these proteins have been further characterized yet. Their putative function, therefore, remains a matter of speculation. It is noteworthy that the apparent molecular weight of the three Gla-proteins reported here, coincide with those of PGP $(27 \mathrm{kDa})$, osteocalcin $(18 \mathrm{kDa})$ and MGP (10 kDa). To date, however, both mRNA and protein levels of only one Gla-protein have been identified in calcified human atherosclerotic plaques, namely MGP." The fact that its specific Iocalization in the lipid-rich calcified areas of the plaque is similar to that in cartilage ultimately undergoing endochondral ossification, strongly suggests a role in the regulation of the mineralization process. We hypothesize that similar to its role in rapidly developing fetal bones, vascular MGP may act as a mineralization inhibitor, either protecting against calcification of the vessel wall or retarding the process.

In conclusion, we have shown the presence of three discrete Gla-proteins in SDSpolyacrylamide gel with apparent molecular weights coinciding with those of PGP, MGP and osteocalcin. Their isolation, however, appeared to be hampered by the presence of contaminating sialic acid rich glycoproteins or proteoglycans. In addition, considerable losses of protein-bound Gla occurred during various isolation procedures, probably because of excessive precipitation. This study shows that conventional biochemical isolation procedures do not lead to a signifi- 
cant purification of the Gla-proteins present in the calcified plaque. Other approaches are needed therefore to investigate the role of Gla-proteins in the atherosclerotic process.

\section{ACKNOWLEDGMENT}

The authors wish to thank dr. R.J.M. Retera, M. Swijen and H. Hendriks from the department of Pathology at the St. Maartensgasthuis in Venlo for their help in providing us with human aorta's. The excellent technical assistance of Dr. B.A.M. Soute, E. Otte, A. Teuben, L.G. Böck, and M.H.J. Knapen is greatly appreciated.

\section{REFERENCES}

1. Stenflo ل, Fernlund P, Egan W, Roepstorff P. Vitamin K-dependent moditications of glutamic acid residues in prothrombin. Proc Natl Acad Sci USA 1974:71:2730-33.

2. Price PA, Otsuka AS, Poser JW, Kristaponis J, Raman N. Characterization of a $\gamma$-carboxyglutamic acid-containing protein from bone. Proc Natl Acad Sci USA 1976;73:1447-51.

3. Lian JB, Skinner M, Glimcher MJ, Gallop P. The presence of $\gamma$ carboxyglutanic acid in proteins associated with ectopic calcification. Biochem Bioph Res Comm 1976:73:349.55.

4. Lian JB, Prien EL Jr, Glimcher MJ, Galtop PM. The presence of protein-bound $\gamma$-carboxygluta mic acid in calcium-containing renal calculi. J Clin Invest 1977;59:1151-7.

5. Levy RJ, Zenker J, Lian JB. Vitamin K-dependent calcium-binding proteins in aortic valve calcifications. J Clin Invest 1980;65:563-6.

6. Vemeer C. $\gamma$ Carboxyglutamate-containing proteins and the vilamin K-dependent carboxylase. Biochem J 1990;266:625-36.

7. Deyl $Z$, Macek $K$, Vancikova $O$, Adam $M$. The presence of $\gamma$-carbokyglutamic acid-containing protein in atheromatous aortate. Bioch Bioph Acta 1979;581:307-15.

8. Levy RJ, Gundberg $C$, Scheinnan $R$. The identification of the vitamin K-dependent bone protein osteocalcin as one of the $\gamma$-carboxyglutamic acid containing proteins present in calcitied atherosclerotic placgue and mineralized heart walves. Atherosclerosis $1983 ; 46: 49-56$.

9. Shanahan CM, Cary NRB, Metcalfe JC, Weissberg PL. High expression of genes for calcification-regulating proteins in human atherosclerotic plaques. J Clin Inwest 1994:93:2393-2402.

10. Boström $\mathrm{K}$, Watson $\mathrm{KE}$. Horn $\mathrm{S}$. Wortham $\mathrm{C}$. Herman $\mathrm{IM}$, Demer LL. Bone morphogenetic protein expression in human atherosclerotic lesions. J Clin Invest 1993;91:1800-9.

11. Severson AR, Ingram RT, Schwartz RS, Fitzpatrick LA. Matrix proteins associated with bone calcification are present in human aortic vascular smooth muscle cells. Circulation 1993;88:1-367.

12. Keeley FW, Sitarz EE. Characterization of proteins from the calcified matrix of atherosclerotic lauman aorta. Atherosclerosis 1983:46:29-40.

13. Levy RI, Lian JB, Gallop PM. Atherocalcin a $\gamma$-carboxyglutamic acid containing protein from atherosclerotic plaque. Biochem Biophys Res Conmun 1979:91:41-9. 
14. Gijbers BMLG, van Haatlem LMM, Soute BAM, Ebberink RHM, Vemeer C. Characterization of a Glacontaining protein from calcified human atherosclerotic plaques. Arteriosclerosis $1990: 10: 991-5$

15. Levy RJ. Howard SL, Oshry Ld. Carboxyglutamic acid (Gla) containing proteins of humant calcified atherosclerotic plaque solubilized by EDTA. Afherosclerosis 1986;59:155-60

16. Maillard C. Berruyer M, Serre CM, Dechavanne M. Delmas PD. Protein-S, a vitamin K-dependent protein, is a bone matrix component synthesized and secreted by osteoblasis. Endocrinology 1992:130:1599-1604.

17. McGrath LT, Ellion RJ. Lipid analysis and fatty acid profiles of individual arterial atherosclerotic plaques. Anal Biochem $1990 ; 187,273-6$.

18. Sedmak JJ, Grossberg SE. A rapid, sensitive and versatile assay for protein using Coomassie brilliant blue G250. Anal Biochem 1977;79:544-52.

19. Kuwada $M$, Katayama $K$. An improved method for the determination of $\gamma$-Carboxyglutamic acid in proteins, bone, and urine. Anal Chem 1983;131:173-9.

20. Laenmli UK. Cleavage of structural proteins during the assembly of the head of bacteriophage T4. Nature 1970:227:680-5.

21. Schüggur $\mathrm{H}$, von Jagow $\mathrm{G}$. Tricine-sodium dodecyl sulfate-polyacrylamide gel electrophoresis for the separation of proteins in the range from 1 ti $100 \mathrm{kDa}$. Anal Biochem 1987;166:368-79.

22. Vie K-SG, Gijsbers BLMG, Vermeer C. A specific colorimetric staining method for $\gamma$-Carboxyglutamic acid-containing proteins in polyacrylamide gel. Anal Biochem 1994 , accepted for publication.

23. Campbetl KP. Maclennan DH, Jorgensen $\mathrm{AO}$. Staining of the $\mathrm{Ca}^{2+}$ proteins, calsequestin, calmodulin, troponin $\mathrm{C}$, and $\mathrm{S}-100$, with the cationic carbocyanine dye "Stains-all". J Biol Chem $1983: 258: 1.1267-73$.

24. Dubray G, Bezard G. A highly sensitive periodic acid-stain for 1,2-diol groups of glycoproteins and polysaccharides in polyacrylamide gels. Anall Biochem 1982;119:325-9.

25. Green MR, Pastewka JW, Peacock AC. Differential staining of phosphoproteins on polyacrylannide gels with a cationic carbocyanine dye. Anal Biochem 1973;56:43-51.

26. Knudson W, Gundlach MW, Schmid TM, Conrad HE. Selective hydrolysis of chondroitin sulfates by hyaluronidase. Biochemistry 1984;23:368-75.

27. Oike $Y$, Kimata K. Shinomura T, Nakazawa K, Suzuki S. Proteinase activity in chondroitin lyases (chondroitinases) and endo- $\beta-D$-galactosidases (keratanase) preparations and a method to abolish their effect on proteoglycan Biochem J 1980;191:203-7.

28. Hudgin RI. Pricer WE. Ashwell G. Stockert RJ, Morrell RJ. The isolation and properties of a I'abbit liwer binding protein specific for asialoproteins. J Biol Chem 1974,249:5536-43.

29. Wessel D. Flugge UI. A nethod for the quantitative recovery of protein in dilute solution in the presence of detergents and lipids. Anal Biochem 1984;138:141-3.

30. Vermeer C, Soute BAM. Hemker HC. A new method for the preparation of artificial factor II veagents from nomal human and bovine plasma. Thromb Res 1977;10:495-507.

31. Gorbunof MJ. Protein chromatography on hydroxyapatite columns. In: Deutcher MP, editor. Methods in enzymology. Guide to protein purification. San Diego: Acadenic Press, $1090: 182: 329-39$.

32. Moos M Jr, Nguryen NY. Liu TY. Reproducible high yield sequencing of proteins electrophoretically separated and transferred to an inert support. J Biol Chem 1988;263:6005-8.

33. Walsh MJ, McDougall J. Witmann-Liebold B. Extended N-terminal sequencing of proteins of Archaebacterial ribosomes bloted from two-dimensional gels onto glass fiber and poly(vinylidenedifluoride) membrane. Biochemistry 1988;27:6867-76.

34. Wight TN. Cell biology of arterial proteoglycans. Arteriosclerosis $1989 ; 9: 1-20$. 
35. Giachelli CM, Bae N, Almeida M, Denhardt DT, Alpers CE, Schwartz SM. Osteopontin is elevated during neointima formation in rat arteries and is a novel component of human atherosclerotic plaques, J Clin Invest 1993:92:1686-96.

36. Badimon JJ, Fuster V. Chesebro JH. Badimon L. Coronary atherosclerosis. A multifactorial disease. Circulation 1993;87(Suppl II):11-3-11-16.

37. Watson KE, Bostrơm K, Ravindranath R, Lam T, Norton B, Demer LL. TGF-B and 25-hydroxycholesterol stimulate osteoblast-like vascular cells to calcify. J Clin Invest 1994;93:2106-13.

38. Merril CR. Gel-staining techniques. In: Deutcher MP, editor. Methods in enzymology. Guide to protein purification. San Diego: Academic Press, 1990;182:477-88.

39. Friedman RD. Comparison of four different silver-staining techniques for salivary protein detection in alkaline polyacrylamide gels. Anal Biochem 1982;126:346-9.

40. Colombo $G$, Fanti $P, Y a o ~ C$, Malluche HH. Isolation and complete amino acid sequence of osteocalcin from canine bone. J Bone Min Res 1993;8:733-43. 



\section{CHAPTER}

8

\section{SUMMARY / SAMENVATTING}





\section{SUMMARY}

Vitamin $\mathrm{K}$ is an essential cofactor for the formation of the unusual aminoacid $\gamma$ carboxyglutamate (Gla) which is found in a limited number of proteins. In these so called "vitamin K-dependent' or Gla-proteins, the Gla-residues are involved in the calcium-dependent binding to negatively charged phospholipid membranes (e.g. the blood coagulation factors FII, VII, IX and X) or to hydroxyapatite (e.g. the bone Gla proteins osteocalcin and matrix Gla-protein (MGP)). In the case of an impaired vitamin $\mathrm{K}$-status, the formation of Gla is hampered and the Glaproteins are synthesized and secreted in a functionally impaired form. These so called undercarboxylated or descarboxy Gla-proteins, lack the aminoacid Gla but contain glutamate (Glu) instead (chapter 1). Up until now, the diagnosis of vitamin K-deficiency has mainly relied on tests measuring the functional activity of the hepatic Gla-proteins involved in blood coagulation. In using the coagulation factors as a marker for vitamin $\mathrm{K}$-status, we must conclude that vitamin $\mathrm{K}$ deficiency is extremely rare in the general population. There is evidence, however, that tests based on blood coagulation factors are not sensitive to a marginal vitamin $\mathrm{K}$-status. ${ }^{1,2}$

The studies described in this thesis are investigations into the relationship between vitamin $K$ and aspects of calcium or bone metabolism (chapters $2,3,4$ ), as well as the vessel wall calcification process occurring in the atherosclerotic plaque (chapters $6,7,9)$.

Vitamin K-status was assessed with the hydroxyapatite binding assay of serum osteocalcin. This assay is based on the 'vitamin K-dependent' property of osteocalcin to bind to hydroxyapatite via its Glamresidues. Serum osteocalcin (irOC) with high affinity for hydroxyapatite (irOC $\mathrm{C}_{\text {bounul }}$ ) is assumed to represent the fully carboxylated fraction, whereas that with low (irOC $\mathrm{rrec}_{\text {) }}$ ) affinity is thought to represent the undercarboxylated fraction. ${ }^{3}$ The hydroxyapatite binding capacity (HBC) (irOC ${ }_{\text {bound }}$ expressed as the percentage of the total irOC levels), can be used as a semi-quantative measure for the Gla-content of serum osteocalcin (Figure 3, chapter 1). Low HBC levels $(<70 \%)$ are commonly lound in subjects with an impaired vitamin $\mathrm{K}$ status such as those using vitamin $\mathrm{K}$-antagonists (chapter 3).

The hydroxyapatite binding assay was validated in a population at ligh risk for a marginal vitamin $\mathbb{K}$ status: the newborn babies (chapter 2). Pregnant women were treated with either vitamin $\mathrm{K}$ (1 mg/day) or a placebo during the last 6 
weeks of their pregnancy. The fact that all babies from the placebo treated group had wery high concentrations of irOC $\mathrm{C}_{\text {free }}$ and $\mathrm{HBC}$ levels as low as those in adults on oral anticoagulant therapy, strongly suggested they had a poor vitamin $\mathrm{K}$ status. This suggestion was confirmed by the observation that the 'vitamin $\mathrm{K}$ treated' babies had significantly lower irOC free and higher $\mathrm{HBC}$ levels. Since no descarboxy-prothrombin was detectable in any of the tested cord blood samples, these results then indicate that the $\mathrm{HBC}$ of serum osteocalcin is a more sensitive marker for measuring vitamin $K$ than tests based on the blood coagulation prothrombin.

In the first part of the study described in chapter 3 we have investigated the extent to which the vitamin $\mathrm{K}$-status affects urinary calcium excretion. This was done in a placebo-controlled study among postmenopausal women. Vitamin Ktreatment appeared to significantly decrease the fasting urinary calcium excretion in the so called fast losers of calcium (calcium/creatinine ratio $>0.5$ ). To investigate whether vitamin $\mathrm{K}$-antagonists would have an opposite effect, we performed a case control study among patients on long-term stable anticoagulant therapy. Only the group of young men (aged 25-45) contained a significantly higher fraction (7/27) of fast losers as compared with the age-matched control group (0/25). The positive association of the fasting urinary calcium with the urinary hydroxyproline excretion $(\mathrm{r}=0.52, \mathrm{p}<0.004)$ indicated that the high calcium excretion in the anticoagulated young men may be related to a high bone resorption.

Chapter 4 deals with the effect of vitamin K-treatment $(1 \mathrm{mg} /$ day during 2 weeks) on serum osteocalcin (irOC) levels in women aged 20-85. Since vitamin $K$-supplementation mainly affected irOC levels in women older than 50 , a second study was performed in elderly women (aged 50-85) with a longer treatment period of 3 months. Vitamin $K$ treatment increased the serum levels of two markers for bone formation (total iroC levels and bone-specific alkaline phosphatase), whereas a $30 \%$ decrease in fasting urinary calcium excretion was noticed in the fast losers of urinary calcium. These findings are supported by several in vitro studies which have shown that vitamin $\mathrm{K}$ stimulates osteocalcin and alkaline phosphatase excretion by osteoblastic cells ${ }^{4}$ and decreases bone resorption. ${ }^{5.6,7}$.

A surprising observation of this study was that vitamin K-treatment mainly increased irOC $C_{\text {bound }}$ levels, whereas the mean iroC $C_{\text {free }}$ levels remained unaffected. This is in contrast with the situation found in newborn babies (chapter 2), who had lower irOC $\mathrm{C}_{\text {free }}$ levels upon vitamin $\mathrm{K}$-treatment. These findings indicate that 
irOC free $($ especially in postmenopausal women) may not only represent undercarboxylated osteocalcin, as assumed up until now. "The results of the study described in chapter 4 indicate that irOC $\mathrm{C}_{\text {fre }}$ may also partly represent osteocalcin fragments, probably derived from the process of bone resorption. Additional support for this view has recently been published by Minisola $e t$ al. ${ }^{8}$ Of interest is that the presence of osteocalcin fragments has recently been confirmed by Garnero et al. who, using a set of various monospecific antibodies, showed that $64 \%$ of the total circulating immunoreactive antigens can be ascribed to osteocalcin fragments. ${ }^{9}$

In the vitamin $\mathrm{K}$-supplementation studies we have performed thus far, we have used a dosage of $1 \mathrm{mg}$ phylloquinone from a pharmaceutical preparation (Konakion"). Because of its highly soluble form, its bioavailability can be expected to be fairly good. We have therefore compared the bioavailability of 1 mg phylloquinone presented in the form of spinach (with or without butter) with that of Konakion" (chapter 5). Compared with Konakion", the absorption of phylloquinone from spinach appeared to be substantially lower. The addition of fat to spinach, did however, enhance the amount of phylloquinone absorbed about 3-fold. This study shows that the amount of bioavailable phylloquinone as estimated from the dietary vitamin $\mathrm{K}$-intake, is far less than assumed up until now. Therefore, studies are needed to investigate the bioavalability of vitamin $\mathrm{K}$ from various sources and the effect of other components of the diet (e.g. the amount of fat) on the absorption of vitamin $\mathrm{K}$.

Besides in bone, Gla-proteins are found in the calcified lesions of the atherosclerotic plaque. An impaired vitamin K-status may therefore affect the development and progression of atherosclerotic calcifications. In the study described in chapter 6.1 we investigated the vitamin $\mathrm{K}$-status in postmenopausal women with or without severe atherosclerotic calcifications. In the nonatherosclerotic women, the nutritional vitamin K-intake decreased considerably with an average of $10.08 \mu \mathrm{g} / \mathrm{day}(95 \% \mathrm{CI}: 9.49-10.67)$, whereas in the atherosclerotic women the vitamin $\mathrm{K}$-intake remained at a constant low level. Women with calcified lesions (mean intake: $189,9 \mu \mathrm{g} / \mathrm{day}$ ) appeared to have a lower age-adjusted nutritional vitamin $\mathrm{K}$-intake of $43 \mu \mathrm{g} /$ day, constituting a difference of $18 \%$. In addition, compared to the non-atherosclerotic women, their atherosclerotic counterparts had a poor vitamin $\mathrm{K}$-status as reflected in their significantly higher rOC $_{\text {free }}$ and lower $\mathrm{HBC}$ levels. These findings are in line with the hypothesis that vitamin $\mathrm{K}$ or Gla-proteins are involved in the development of vessel wall calcifications. 
Chapter 6.2 reports the associations between the presence of atherosclerotic calcifications, bone mass and markers for vitamin $\mathrm{K}$-status in the populationbased study described in chapter 6 . Women with atherosclerotic calcifications had an $8 \%$ lower bone mass (mean difference of $3.15 \mathrm{~mm}^{2}, 95 \% \mathrm{Cl}: 0.18-6.72$ ) and in addition, both markers for vitamin $\mathrm{K}$ status were associated with bone mass (irOC frec $_{\text {f }}: \mathrm{r}=-0.47, \mathrm{p}=0.013 ; \mathrm{HBC}: \mathrm{r}=0.57, \mathrm{p}=0.002$ ). The negative association of irOC $_{\text {irse }}$ with bone mass is of special interest, since recent findings indicate that thigh irOC $\mathrm{Crret}_{\mathrm{T}}$ levels are associated with a high risk for developing osteoporotic hip fractures. ${ }^{10}$ Thus both the lower bone mass, and the higher irOC $\mathrm{C}_{\text {free }}$ levels in the atherosclerotic women, indicate that they may be at a high risk for osteoporotic fractures. The findings of this study support the view that osteoporosis and atherosclerosis are two related processes and that vitamin $\mathrm{K}$ may act as one of the common denominators in both disease states.

In chapter 7.2 we have confirmed that substantial amounts of non-dialysable, protein-bound Gla are present in the calcified human atherosclerotic plaque. With a specific colorimetric staining method described in Chapter 7.1, we have been able to identify three Gla-proteins in the calcified human atherosclerotic plaque with apparent molecular weights of 10,18 and $27 \mathrm{kDa}$. Their further isolation and characterization, however, has proven to be extremely difficult. One of the contributing factors may be the abundant presence of contaminating sialoglycoproteins or proteoglycans. This study indicates that conventional biochemical techniques are insufficient to investigate the role of vitamin $\mathrm{K}$ or Gla-proteins in atherosclerotic calcifications.

The initial report that a suboptimal vitamin $\mathrm{K}$-status is common in postmenopausal women has been confirmed by the studies described in this thesis (chapter $3,4,6$ ), and by reports from other investigators. ${ }^{1.10,11}$ In addition, evidence has been obtained that a suboptimal vitamin $\mathrm{K}$-status may affect bone metabolism as well as the process of vessel wall calcifications.

The measurement of the two irOC fractions differing in their ability to bind to hydroxyapatite, has shown to be a promising tool for assessing one's (bone) tissue vitamin $\mathrm{K}$-status. The additional value of this distinction is illustrated by the finding of Szulc et al. that irOC ${ }_{\text {free }}$ may be used as a marker for developing hip fractures." The hydroxyapatite binding assay is a semi-quantative measure and can therefore only be used as an estimate of the degree of carboxylation of serum osteocalcin. Tests are needed which have been precisely characterized with respect to the immunoreactive forms of osteocalcin that are detected, and are able to directly detect undercarboxylated irOC levels. 
The finding that vitamin K-status may affect bone metabolism and atherosclerotic calcifications raises the question of whether the recommended daily allowances (RDA) for vitamin $\mathrm{K}$ should be reconsidered. The future use of extra-hepatic Gla-proteins (osteocalcin, MGP) may become important tools in reestablishing the RDA-values. Furthermore, studies aimed to investigate the efficacy of vitamin $\mathrm{K}$ (phylloquinone and menaquinone) absorption from different food products are needed. 


\section{SAMENVATTING}

Vitamine $\mathrm{K}$ is een essentueje cofactor in de aanmaak van het ongewone aminozuur $\gamma$-carboxyglutaminezuur (Gla) dat in een beperkt aantal eiwitten voorkomt. In deze zogenaamde "vitamine $\mathbb{K}$-afhankelijke' of Gla-eiwitten, zijn de Gla-residuen betrokken in de calcium-afhankelijke binding aan negatief geladen fosfolipid membranen (zoals bij de bloedstollingsfactoren FII, VII, IX en X) of aan hydroxyapatiet (zoals bij de Gla-bevattende boteiwitten osteocalcine en matrix Gla proteine (MGP)). Bij een slechte vitamine K-status, zal de aanmaak van Gla verstoord zijn en zullen de Gla-eiwitten aangemaakt en uitgescheiden worden in een niet-functionele vorm. Deze zogenaamde ondergecarboxyleerde of descarboxy Gla-eiwitten, bevatten glutaminezuur (Glu) in plaats van Gla (hoofdstuk 1). Om de diagnose vitamine $\mathrm{K}$-deficiëntie vast te stellen heeft men tot nu toe hoofdzakelijk gebruik gemaakt van testen die gevoelig zijn voor de functionele activiteit van de hepatische bloedstollings Gla-eiwitten. Als we de stollingseiwitten gebruiken als merkstof voor de vitamine $\mathrm{K}$-status, valt op dat een vitamine $\mathrm{K}$-deficiëntie in de algemene bevolking zeldzaam is. Er zijn echter aanwijzingen dat testen gebaseerd op bloedstollingsfactoren, niet gevoelig genoeg zijn om een gering tekort aan vitamine $\mathrm{K}$ aan te tonen. ${ }^{1,2}$

De studies in dit proefschrift beschrijven het onderzoek naar de relatie tussen vitamine $\mathrm{K}$ en aspecten van het calcium- of botmetabolisme (hoofdstukken 2,3,4), alsook de relatie met de verkalkingsprocessen in de atherosclerotische plaque (hoofdstukken 6,7,9).

De vitamine K-status werd onderzocht met behulp van de 'hydroxyapatiet bindings assay' van het serum osteocalcine. Deze assay is gebaseerd op de 'vitamine K-athankelijke' eigenschap van osteocalcine om aan hydroxyapatiet te binden met behulp van zijn Gla-residuen. Het immunureactieve serum osteocalcine (irOC) met een hoge alfiniteit voor hydroxyapatiet (irOC ${ }_{\text {bound }}$ ) wordt verondersteld de gecarboxyleerde fractie te zijn, terwijl de osteocalcine fractie met een lage affiniteit voor hydroxyapatiet het ondergecarboxyleerde osteocalcine (irOC $\mathrm{C}_{\text {free }}$ ) vertegenwoordigt. ${ }^{3}$ De hydroxyapatiet bindings capaciteit $(\mathrm{HBC})$ ( $=\mathrm{irOC}_{\mathrm{bound}}$ uitgedrukl als een percentage van het totale irOC gehalte), kan aangewend worden als een semi-kwantitatieve maat voor het Gla-gehalte van het serum osteocalcine (Figuur 3, hoofdstuk 1). Lage HBC gehaltes $(<70 \%)$ komen frequent voor bij diegenen met een verminderde vitamine $\mathrm{K}$-status zoals diegenen die vitamine $\mathrm{K}$ antagonisten gebruiken (orale antistollingsmiddelen zoals sintrom mitis (hoofdstuk 3). 
De hydroxyapatiet bindings assay werd gevalideerd in een bekende risicogroep voor vitamine K-deficiëntie: de pasgeborenen (hoofdstuk 2). Zwangere vrouwen werden gedurende de laatste 6 weken van hun zwangerschap behandeld met vitamine $\mathrm{K}$ ( $1 \mathrm{mg} / \mathrm{dag})$ of een placebo. Het feit dat alle baby's uit de met een placebo behandelde groep zeer hoge concentraties irOC $\mathrm{C}_{\text {irec }}$ hadden, met $\mathrm{HBC}$ gehaltes vergelijkbaar met die van volwassenen onder orale antistolling, suggereert heel sterk dat ze een slechte vitamine $\mathrm{K}$ status hebben. Dit werd ondersteund door de observatie dat de 'vitamine $\mathrm{K}$ behandelde' baby's significant lagere rOC $_{\text {free }}$ en hogere $\mathrm{HBC}$ gehaltes hadden. Aangezien descarboxy-protrombine in geen van de geteste navelstreng bloedmonsters werd aangetroffen, geven deze resultaten aan dat het HBC gehalte van het serum osteocalcine een gevoeligere marker is voor het meten van de vitamine $\mathrm{K}$ status dan testen, gebaseerd op de bloedstollingsfactor protrombine.

In het eerste deel van het onderzoek zoals beschreven in hoofdstuk 3, hebben wij onderzocht in welke mate de vitamine K-status de calcium uitscheiding in de urine beïnvloedt. Het betreft een placebo-gecontroleerde studie onder postmenopauzale vrouwen. Behandeling met vitamine $\mathrm{K}$ leidde tot een significante daling van de nuchtere calcium uitscheiding in de urine bij vrouwen met een hoge calcium uitscheiding (bij de zogenaamde fast losers: calcium/creatinine ratio > 0.5). Of vitamine $\mathrm{K}$-antagonisten juist een tegenovergesteld effect zouden hebben werd onderzocht in een case control onderzoek bij patiënten onder langdurige, stabiele antistollingstherapie. Alleen bij de jonge mannen (25-45 jr) werd een significant hoger aantal fast losers (7/27) aangetroffen dan in een leeftijds-gematchte controle groep 0/25). De positieve associatie van de nuchtere calcium uitscheiding in de urine met de hydroxyproline uitscheiding $(\mathrm{r}=0.52, \mathrm{p}<0.004)$, geeft aan dat de hoge calcium uilscheiding in de geantistolde groep jonge mannen gerelateerd is aan een hoge botresorptie.

Hoofdstuk 4 beschrijft de effecten van vitamine $\mathrm{K}$-behandeling ( $1 \mathrm{mg} /$ dag gedurende 2 weken) op het serum osteocalcine (irOC) gehalte bij vrouwen van 20 $85 \mathrm{jr}$. Hieruit bleek dat vitamine $\mathrm{K}$ behandeling hoofdzakelijk een effect had op het irOC gehalte bij de vrouwen ouder dan $50 \mathrm{jr}$. Er werd daarom een tweede, langdurige studie verricht bij oudere vrouwen ( $50-85 \mathrm{jr}$ ). Vitamine $\mathrm{K}$ behandeling gedurende 3 maanden leidde tot een verhoging van het serum gehalte van twee merkstoffen woor botworming (totale irOC gehalte en het bot-alkalische fosfatase en een afname met $30 \%$ van de calcium uitscheiding in de urine bij de 'fast losers". Deze bevindingen worden ondersteund door verschillende in vitro studies 
die aantonen dat vilamine $\mathrm{K}$ de osteocalcine en alkalische fosfatase uitscheiding door osteoblast cellen stimuleert en de botresorptie doet afnemen. ${ }^{4,6,7}$

Een verrassende observatie van deze studie was de bevinding dat vitamine $\mathrm{K}$ behandeling hoofdzakelijk het irOC $\mathrm{b}_{\text {wound }}$ gehalte deed toenemen, terwijl het gemiddelde $\mathrm{irOC}_{\text {free }}$ gehalte hetzelfde bleef. Dit is in tegenstelling tot de resultaten bij de pasgeborenen (hoofdstuk 2), bij wie de rOC $_{\text {fret }}$ spiegels juist daalden na vitamine $\mathrm{K}$ therapie. Deze gegevens wijzen erop dat irOC $\mathrm{C}_{\mathrm{fres}}$ (met name bij postmenopauzale vrouwen), in tegenstelling tot wat tot nu toe werd aangenomen, mogelijk niet alleen het ondergecarboxyleerde osteocalcine voorstelt. ${ }^{2.3}$ De resultaten van de studies beschreven in hoofdstuk 4 wijzen erop dat irOC $\mathrm{C}_{\text {free }}$ ook voor een deel bestaat uit osteocalcine fragmenten, mogelijk afkomstig uit het botresorptie proces. Deze visie wordt ondersteund door de recente studie van Minisola et al. ${ }^{8}$. De aanwezigheid van circulerende osteocalcine fragmenten is recent bevestigd door Garnero et al. die, met behulp van verschillende monospecifieke antilichamen, aantoonde dat $65 \%$ van het totale immuunreactieve circulerend antigeen toegeschreven dient te worden aan osteocalcine fragmenten."

In de vitamine $\mathrm{K}$-suppletie studies die wij tot nu toe verricht hebben, is er een dosering gebruikt van $1 \mathrm{mg}$ fylloquinon (= vitamin $\mathrm{K}_{1}$ ) afkomstig van een farmaceutisch preparaat (Konakion"). Vanwege zijn hoog oplosbare vorm, is de te verwachten biologische beschikbaarheid groot. Wij hebben daarom de biologische beschikbaarheid van $1 \mathrm{mg}$ fylloquinon in de vorm van spinazie (met of zonder boter) vergeleken met die van Konakion" (hoofdstuk 5). De absorptie van fylloquinon uit spinazie bleek substantieel lager te zijn dan die uit Konakions. Toevoeging van vet aan spinazie, verbeterde echter de absorptie van fylloquinon uit spinazie met een factor 3. Deze studie geeft aan dat de hoeveelheid biologisch beschikbare fylloquinon, zoals die geschat wordt uit de dietaire vitamine $\mathrm{K}$ inname, aanzienlijk minder is dan tot nu toe werd aangenomen. Er zijn daarom studies nodig die de biologissche beschikbaarheid van vitamine $\mathrm{K}$ uit verschillende voedingsbronnen en de effecten van andere componenten uit het dieet (zoals de hoeveelheid vel) op de absorptie van vitamine $\mathrm{K}$ bestuderen.

Behalve in bot, worden Gla-eiwitten ook gevonden in de verkalkte atherosclerotische plaque. Een precaire vitamine $\mathbb{K}$-status zou daarom de vorming en progressie van de atherosclerotische verkalkingen kunnen beïnvloeden. In hoofdstuk 6.1 wordt een studie beschreven die de vitamine K-status onderzoekt in postmenopauzale vrouwen met of zonder ernstige atherosclerotische verkalkingen van de vaatwand. In de niet-atherosclerotische vrouwen blijkt de vitamine $\mathrm{K}$-inname via de voeding aanzienlijk af te nemen met het toenemen van de leeftijd: gemiddeld 
$10.08 \mu \mathrm{g} / \mathrm{dag}$ per jaar (95\% betrouwbaarheidsinterval $(\mathrm{BI}): 9.49-10.67$ ), terwijl de vitamine $\mathrm{K}$ inname in de atherosclerotische vrouwen op een constant laag niveau blijft. Vrouwen met atherosclerotische verkalkingen (geniddelde vitamine K-inname: $189,9 \mu \mathrm{g} / \mathrm{day}$ ) bleken een $18 \%$ (43 $\mu \mathrm{g} / \mathrm{dag}$ ) lagere vitamine $\mathrm{K}$-inname (leeftijds-gecorrigeerd) te hebben. Bovendien bleken de vrouwen met atherosclerotische verkalkingen een slechtere weefsel vitamine $\mathrm{K}$-status te hebben, zich uitend in statistisch significant hogere irOC $\mathrm{C}_{\text {fre }}$ en lagere $\mathrm{HBC}$ gehaltes. Deze bevindingen ondersteunen de hypothese dat vitamine $\mathrm{K}$ of Gla-eiwitten betrokken zijn in de ontwikkeling van vaatwand verkalkingen.

Hoofdstuk 6.2 beschrijft de associatie tussen de aanwezigheid van atherosclerotische verkalkingen, botmassa en markers voor de vitamine $\mathrm{K}$ status in de populatiestudie beschreven in hoofdstuk 6.1. Vrouwen met atherosclerotische verkalkingen bleken een $8 \%$ lagere botmassa (gemiddeld verschil van $3.15 \mathrm{~mm}^{2}, 95 \% \mathrm{BI}$ : $0.18-6.72$ ) te hebben. Bovendien waren beide markers voor vitamine $\mathrm{K}$ status gecorreleerd an de botmassa (irOC $\mathrm{frut}_{\mathrm{i}}: \mathrm{r}=-0.47, \mathrm{p}=0.013 ; \mathrm{HBC}: \mathrm{r}=0.57$, $\mathrm{p}=0.002$ ). De negatieve associatie van iroC free met de botmassa is met name interessant, omdat recente gegevens erop wijzen dat hoge irOC $_{\text {free }}$ gehaltes geassocieerd zijn met een hoger risico voor het ontwikkelen van osteoporotische heup fracturen. ${ }^{10}$ Zowel de lagere botmassa als de hogere irOC $\mathrm{C}_{\text {free }}$ gehaltes in de atherosclerotische vrouwen geven aan dat atherosclerotische vrouwen een hoger risico hebben voor osteoporotische fracturen. Deze bevindingen ondersteunen de hypothese dat osteoporose en atherosclerose twee aan elkaar gerelateerde processen zijn, waarbij een tekort aan vitamine $\mathrm{K}$ een belangrijke rol speelt.

In hoofdstuk 7.2 bevestigen wij dat aanzienlijke hoeveelheden niet-dialyscerbare eiwitgebonden Gla aanwezig is in de verkalkte humane atherosclerotische plaque. Met een specifieke colorimetrische kleuring, beschreven in Hoofdstuk 7.1, hebben wij de aanwezigheid van drie Gla-eiwitten in de verkalkte humane atherosclerotische plaque aangetoond, met een moleculair gewicht van 10,18 en 27 kDa. Hun isolatie en karakterisatie bleek echter extreem moeilijk te zijn. Eén van de bijdragende factoren is waarschijnlijk de overvloedige aanwezigheid van contaminerende sialo-glycoproteines of proteoglycanen. Deze studie geeft aan dat conventionele biochemische technieken niet voldoende zijn om de rol van vitamine $\mathrm{K}$ of Gla-eiwitten in atherosclerotische verkalkingen te onderzoeken. 
De waarneming dat een suboptimale vitamine $K$ status veelvuldig voorkomt bij postmenopatuzale vrouwen werd bevestigd door de studies beschreven in dit proefschrift (hoofdstuk $3,4,6$ ) en die van andere onderzoekers. ${ }^{1,10,11}$ Bovendien hebben wij aanwijzingen gevonden dat een marginale vitamine $K$-status zowel het botmetabolisme als het proces van vaatwandverkalkingen kan beïnvloeden.

De bepaling van de twee irOC fracties, met een verschillende affiniteit voor hydroxyapatiet, blijkt een veelbelovende manier te zijn om iemands (bot) weefsel vitamine $\mathbb{K}$-status te bepalen. De additionele waarde van deze bepaling wordt geillustreerd door de bevinding van Szulc et al. dat irOC free gebruikt kan worden als risicoindicator voor een heupfractuur. ${ }^{10}$ De hydroxyapatiet bindings assay is een semi-kwantitatieve meting en kan daarom alleen gebruikt worden als een schatting van de carboxyleringsgraad van het serum osteocalcine. Er zijn daarom bepalingsmethodes nodig, die precies gekarakteriseerd zijn met betrekking tot de immuunreactieve vormen van het osteocalcine dat ze detecteren, en die tevens in staat zijn om direct het ondergecarboxyleerde osteocalcine aan te tonen.

De inzichten dat de vitamine K-status het botmetabolisme en het proces van atherosclerotische verkalkingen beinvloedt roept de vraag op of de huidige aanbevolen dagelijkse hoeveelheid vitamine $\mathrm{K}$ niet heroverwogen dient te worden. Het is de verwachting dat in de toekomst het gebruik van extra-hepatische Gla-eiwitten (zoals osteocalcine, MGP en PGP) belangrijke hulpmiddelen zullen zijn om de dagelijks aanbevolen hoeveelheid vitamine $K$ te bepalen. Studies die de efficiëntie van vitamine $\mathrm{K}$ absorptie (zowel fylloquinon als menaquinon!) uit verschillende voedingsbronnen bestuderen zijn bovendien aangewezen.

\section{REFERENCES}

1. Ferland $G$, Sadowski JA. O'Brien ME. Dietary induced subclinical vitamin $K$ deficiency in normall human subjecis. IClin livest 1993:9:1761-8.

2. Knapen MHJ. Hamulyák $\mathrm{K}$. Vermeer $\mathrm{C}$. The effect of vitamin $\mathrm{K}$ supplementation on circulating osteocalcin (bone Gla-protein) and urimary calcium excretion. Ann Int Med 1989;11:1001-5.

3. Price PA, Williamson $M K$, Lothringer JW. Origin of the vitamin $K$-dependent bone protein found in plasma and its clearance by kidney and bone. J Biol Chem 1981;256:12760-6.

4. Akedo Y, Hosoi T. Inoue S, Ikegami A. Mizuno Y, Kaneki M, Nakamura T, Ouchi Y, Orimo H. Vitamim $K_{2}$ nodulates proliferation and function of osteoblastic cells in vitro. Biochem Biophys Res Commun 1992;187:814-20.

5. Hara K. Akiyama $Y$. Tajima T. Shiraki M. Menatetrenone inhibits bone resorption partly through inhibition of $\mathrm{PGE}_{2}$ syndhesis in vitro. J Bone Miner Res 1993:8:535-42.

6. Akiyama $Y$. Hara K, Ohkawa 1 , Tajima $T$. Effects of menatetrenone on bone loss induced by ovariectomy in rats. Japan J Pharmacol 1993:62:145-153. 
7. Koshihara $Y$, Hoshi $K$. Shiraki M. Viramin Ko (menatetrenone) inthibits prostagtandin synthesis in culured human osteoblast-iike periosteal cells by inhibiting prostagyandin H synthase activity. Biochem Pharmacol 1993:46:1355-62.

8. Minisola S, Carnevale V, Pacini MT, Romagnoli E. Scarnechia L. Rosso R. Minisola G, Mazzuoli GF. Serum osteocalcin in metabolic diseases: what is its real significance? I Endocin Invest 1993; 16:277-9.

9. Gamero P. Grimeaux M, Seguin P, Delmas PD. Characterization of immunoreactive forms of human osteccalcin generated in wiwo and in vitro. I Bone Miner Res 1994:9:255-64.

10. Szulc P, Chapuy MC. Meunier PJ, Delmas PD. Serum undercarboxylated osteocalcin is a marker of the risk of hip fracture in elderly women. J Clin Invest $1993,91: 1769-74$.

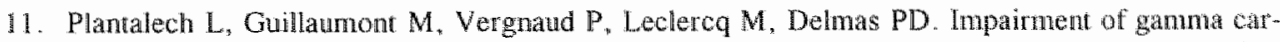
boxylation of circulating osteocalcin (bone Gla protein) in elderly women. I Bone Miner Res $1991 ; 6: 1211-6$. 


\section{DANKWOORD}

Geen enkel (promotie) onderzoek is het werk van één persoon en met name het onderzoek beschreven in dit proefschrift is daar een voorbeeld van.

Op de eerste plaats wil ik de vele proefpersonen bedanken die bereid zijn geweest deel te nemen an het vitamine $\mathrm{K}$-onderzoek. Hun medewerking is van essentieel belang geweest.

Dr. C. Vermeer, beste Kees. Jou ben ik veel dank verschuldigd. Jou (verrassings) bezoekjes op het lab zal ik nooit vergeten, nog steeds verdenk ik je ervan ergens een verborgen camera geinstalleerd te hebben. Jij was altijd in voor het doen van de gekste proefjes (mits goed beargumenteerd!) en was altijd bereid als (bloed) donor op te treden. Jij bent in staat om op een niet-autoritaire manier leiding te geven en mensen te inspireren en te stimuleren tot het verrichten van goed onderzoek.

Dr. K. Hamulyák, Karly. Jou wil ik bedanken voor het vertrouwen dat je altijd in mij heb gehad. Ondanks je drukke werkzaamheden stond je deur altijd voor mij open. Ik bewonder jouw heldere kijk op de materie en jouw vermogen die van een andere kant te belichten. Jouw enthousiasme voor het wetenschappelijk onderzoek werkt aanstekelijk.

Marjo, de leerzame en gezellige uurtjes in de kamer, op het lab en tijdens congressen zullen mij altijd bij blijven! Jij bezit de eigenschapen waar menig ondezoeker jaloers op mag zijn: technisch zeer vaardig en theoretisch goed onderbouwd. Jouw sociale vaardigheden zijn uniek en tevens van essenticel belang geweest voor onze groep (ik hoop ooit jou prik-vaardigheden te kunnen evenaren!).

Birgit, ook jij bedankt voor alle hulp en het opleiden tot een onderzoeker. Ik heb veel van jou geleerd en heb altijd een beroep op je kunnen doen. Ik waardeer het zeer dat jij zoveel overuren heb gemaakt om alles toch nog snel af te krijgen! Jouw wastberadenheid en doorzettingsvermogen zijn bewonderenswaardig (en essentieel voor een goede onderzoeker).

Monique, ondanks alle tegenslagen ben jij toch stug door blijven werken aan het PGP-onderzoek. Jou bijdrage daaraan is zeer belangrijk geweest. Bedankt voor je uitstekende begeleiding en hulp.

Berry, jij bent in staat om de moeilijkste proefjes gemakkelijk te laten lijken. Bedankt voor het inwijden in de wereld van de biochemie, HPLC en het carboxyleren. Je was een byzonder fijne collega en stond altijd klaar om een handje mee te helpen mee te helpen.

Jacintha, Roger en Judy, bedankt voor de leuke samenwerking. 
Het werk van de aorta-'strippers' is van groot belang geweest woor het onderzoek. Zonder hun hulp was een belangrijk deel van het onderzoek ommogelijk geweest! Zij zorgden regelmatig voor de nodige 'spanning' in het 'saaie' lableven. Dank hiervoor aan de hierboven genoemde collega's en aan een ieder die hieraan heeft meegeholpen. Een aparte en eervolle vermelding verdienen natuurlijk de 'profs': Eddy Otte, Annemieke Teuben en Liane Böck.

De bijdrage van dr. R.J.M. Retera en de heren M. Swijen and H. Hendriks van de afdeling pathologie van het St. Maartensgasthuis te Venlo dient eveneens vermeld te worden. Zonder hun hulp bij het beschikbaar stellen en verzamelen van de aorta's was een deel van dit onderzoek onnmogelijk geweest.

Prof. Hemker wil ik bedanken voor het vertrouwen en de mogelijkheid om bij hem te kunen promoveren.

Mariet Molenaar, ik kon altijd een beroep op jou doen, met name gedurende de laatste uren van mijn promotie. De gezellige momenten op het secretariaat en je belangstelling voor het thuisfront zal ik niet vergeten. Trees Camphuisen en Gertie Wijckmans, ook jullie bedankt voor de hulp en gezelligheid.

Prof. Dr. P.J. Brombacher, Dr. G. Hornstra, Prof. Dr. J.A. Knotnerus, Prof. Dr. A.C. Nieuwenhuijzen Kruseman en Dr. M.J. Shearer ben ik erkentelijk voor hun bereidwilligheid zitting te nemen in de beoordelingscommissie.

Mijn moeder wil ik speciaal vermelden. Lieve moeder, oma Isa, ik bewonder jou doorzettingsvermogen en het feit dat jij al die jaren ondanks alles, toch nog optimistisch gebleven bent. Jij hebt ons laten zien dat je nooit te oud bent on te leren!

Duizendmaal dank aan oma Gien. Wij konden altijd een beroep op u doen! Zonder uw hulp en betrokkenheid was het nooit zo verlopen. Bedankt voor de dagen dat wij echt konden uitslapen!

Lieve Karin en Cate. Ook jullie bedankt voor jullie vriendschap. Jullie "oppassers' te noemen is een understatement voor het enthousiasme en fanatisme waarmee jullie met onze kinderen omgaan. Cate, bedankt woor het corrigeren van de Engelse tekst, jij hebt noodgedwongen 'het voorrecht' gehad als een van de eersten mijn hele proefschrift te moeten lezen.

Beste Rob, bedankt voor het ontwerpen van de omslag. Jouw enthousiasme zal ik niet vergeten. De snelheid waarmee het ontwerp van de omslag af was, heeft alleen motiverend gewerkt.

Lieve Liane, jij hebt niet alleen thuis, maar ook op het lab bijgedragen aan dit proefschrift. Er zijn geen woorden om mijn grote bewondering en dank voor jou in uit te drukken... 



\section{LIST OF PUBLICATIONS}

1. Jie $\mathbb{K}$-SG, Hamulyák K, Gijsber BLMG, Roumen FIME, Vermeer C. Serum osteocalcin as a marker for vitamin $\mathrm{K}$-status in pregnant women and their newborn baby's. Thromb Haenost 1992;68:388-91.

2. Jie K-SG. Gijsbers BLMG, Knapen MHJ, Hamulyak K. Frank HL, Vermeer C. Effecis of vitamin $\mathrm{K}$ and oral anticoagulants on urinary calcium excretion. Brit J Haem 1993:83:100-4.

3. Jie K-SG, Knapen MHJ, Heflemons BSP. Hamulyak $K$. Vemeer C. Vitamine $K$ : nieuwe inzichten in de relatie met het bot metabolisme. Ned Tijd $v$ Geneesk 1995;139:875-80.

4. Jie K-SG, Gijsbers BLMG, Vermeer C. A specific colorimetric staining method for $\gamma \sim$ carboxyglutamic acid-containing proteins in polyacrylamide gel. Anal Biochen 1995:224:163-5.

5. Jie K-SG, Bos ML, Vermeer C. Witteman JCM. Grobbee DE. Vitamin K intake and osteocatw cin levels in women with and without aortic atherosclerosis: a population-based study. Atherosclerosis 1995, In press.

6. Vermeer $\mathrm{C}$, Jie K-SG, Knapen MHJ. Rolle of vitamin $\mathrm{K}$ in bone metabolism. Anmu Rev Nurr 1995, accepted for publication.

7. Knapen MHJ, Jie K-SG. Hanulyák K, Vermeer $\mathrm{C}$. Vitamin $\mathrm{K}$ inducedchanges in markers for osteoblast activity and urinary calcium loss. Calcif Tiss Int 1993:53:81-5.

8. Vermeer $\mathrm{C}$, Knapen MHJ, Jie K-SG, Grobbee DE. Physiologic importance of exirahepatic vitamin $\mathrm{K}$ - dependent carboxylation reactions. Amn NY Acad Sei 1992;669:21-33.

9. Groenen-van Dooren MCL, Soute BAM, Jie K-SG. Thissen HHW, Vermeer C. The relative effects of phylloquinone and menaquinone on the blood coagulation factor synthesis in vitamine K-deficient rats. Biochem Pharmacol 1993:46:433-7.

10. Vermeer C, Jie K.SG, Hellemons BSP. Hamulyák K, Vermeer C, Kanapen MHJ. Effects of vitamin $\mathrm{K}$ and oral anticaagulants on calcium netabolism. In: "The use of oral anticoagulants in Europe". Fernández MA, editor. Barcelona: Grafico FM, 1994:17-29.

11. Vermeer $\mathrm{C}$, Knapen $\mathrm{MHJ}$, Jie $\mathrm{K}-\mathrm{SG}$. Effect of vitamin $\mathrm{K}$ and coumarin derivatives on calcium and bone metabolism. In: 'Challenges of Modern Medicine', vol. 7 (ed. Burckhardt F). AresSerono Symposia, Geneva.

13. Knapen MHJ, Jie K-SG, Vermeer $\mathrm{C}$. Vitamin $\mathrm{K}$ status affects markers for bone metabolism. In: 'Challenges of Modern Medicine', wol 7. (ed. Burckhardt F) Ares-Serono Symposia, Geneva.

14. Vermeer $\mathrm{C}$, Knapen MHJ, Je K.SG, Cräcun A. Circulating osteocalcin and urinary Gla as markers for vitamin $K$ status. In: "Vitamin $K$ in infancy". (ed. Sutor AHO). Schatauer Verlad. Suttgart. (In press).

\section{Abstracts}

1. Hamulyák K, Knapen MHग, Jie GKS, Vermeer C. The effecls of long term anticoagulan! therapy on urinary calcium excretion in postmenopatsal women Neth J Med 1990; 37. A24.

2. Knapen MHI, Jie GKS, Hamulyák K. Vermeer C. Vitamin K-deficiency redefined. Thromb Haemost 1991:65,671.

3. Jie K-SG, Gijsbers BLMG, Knapen MHJ, Hamulyák $K$, Vermeer $C$. The effect of oral anticoagulants on the urinary calcium excretion. Thromb Haemost 1991:65,671.

4. Jie K-SG. Hamulyăk K, Gijsbers BLMG. Knapen MHJ, Vermeer C. Occurence of undercarboxylated asteocalcirn in neonates: relation to vitamin $\mathrm{K}$ status. Int J Vit Nutr Res 1993:63:324.

5. Knapen MHJ. Hamulyák $K$, Jie $K-S G$, Vermeer $C$. Effects of vitamin $K$ in postmanopaus! women. Int J Vit Nutr Res 1993:63:324.

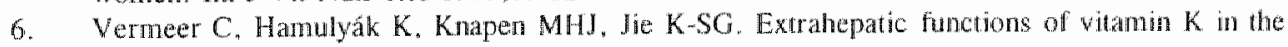
human. Int J Vit Wutr Res 1993:63:324.

7. Hamulyák K. Jie K-SG, Schauwart $A$, Vermeer F. Blood platelet- and plasma plasminogen acrivator inhibitor (PAI) in stable coronary artery disease. Thromb Hacmosi 1993,813

8. Jie K-SG, Knapen MHJ, Bots ML, Vermeer C. Grobbee DE. Vitamin K status and bone mass in postmenopausal women with and without atherosclerosis. Ares Serono proceedings May 5 7,1995 , vol. 7 . 



\section{CURRICULUM VITAE}

De auteur van dit proefschrift werd op 18 januari 1964 geboren te Paramaribo (Suriname). Hij behaalde het diploma Atheneum-B aan het Jeroen Bosch College te 's-Hertogenbosch. In 1983 werd de studie geneeskunde aangevangen aan de Rijksuniversiteit Limburg. Van 1985 tot 1986 was hij student-assistent bij de vakgroep Interne Geneeskunde (dr. B. Schutte, Prof.dr. G.H. Blijham), waar hij onderzoek verrichtte naar de flowcytometrische detectie van oestrogeen- en progesteronreceptoren in mammatumorcellen. Het artsexamen werd behaald in 1990.

Vanaf 1990 was hij werkzaam als assistent in opleiding (A1O) bij de vakgroep Biochemie van de Rijksuniversiteit Limburg, alwaar hij onder leiding van Dr. C. Vermeer en Dr. K. Hamulyák gewerkt heeft aan het onderzoek zoals beschreven in dit proefschrift. Voor een deel van het onderzoek (The effect of oral anticoagulants on the urinary calcium excretion) kreeg hij in 1991 de 'Young, Investigators Merit Traval Award' (XIIth Congress ISTH, Amsterdam).

Sinds oktober 1994 is hij in opleiding tot internist in het Academisch Ziekenhuis Maastricht (opleider: Prof. dr. H.F.P. Hillen). 